\title{
HYDROLOGY AND WATER CHEMISTRY OF AN ABANDONED SURFACE COAL MINE, SOUTHWESTERN HENRY COUNTY, MISSOURI--1984-86
}

By Dale W. Blevins

U.S. GEOLOGICAL SURVEY

Water-Resources Investigations Report 90-4047

Prepared in cooperation with the MISSOURI DEPARTMENT OF NATURAL RESOURCES, LAND RECLAMATION COMMISSION

Rella, Missouri 


\section{U.S. DEPARTMENT OF THE INTERIOR \\ MANUEL LUJAN, JR., Secretary}

\section{U.S. GEOLOGICAL SURVEY \\ Dallas L. Peck, Director}

For additional information write to:

\section{District Chief}

U.S. Geological Survey

1400 Independence Road

Mail Stop 200

Rolla, Missouri 65401
Copies of this report can be purchased from:

U.S. Geological Survey

Books and Open-File Reports

Federal Center, Bldg. 810

Box 25425

Denver, Colorado 80225 


\section{CONTENTS}

Page

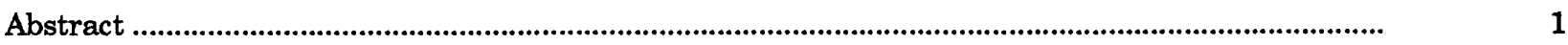

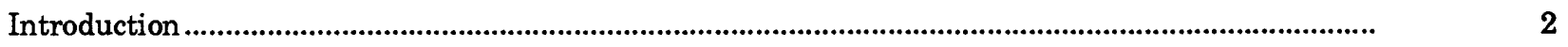

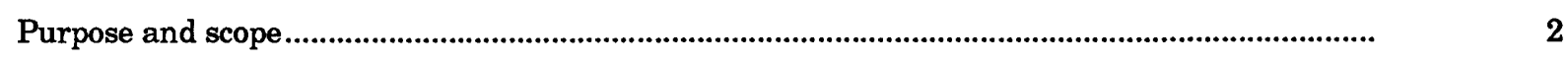

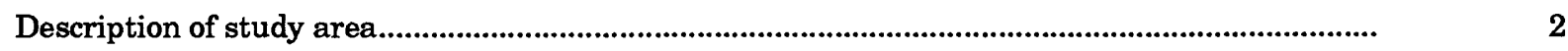

Methodology ................................................................................................................................

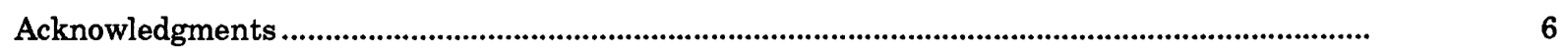

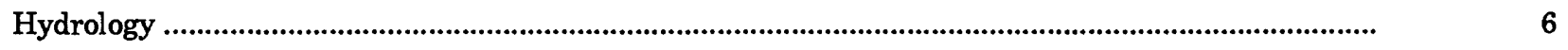

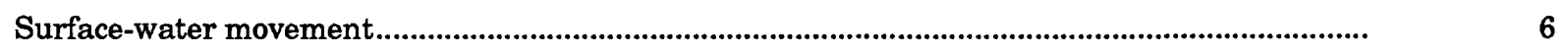

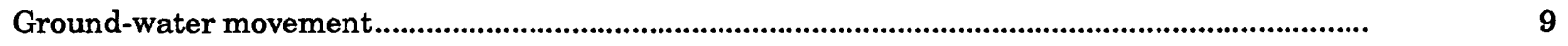

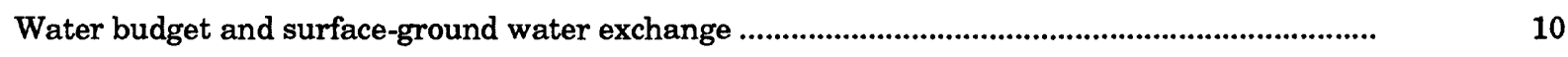

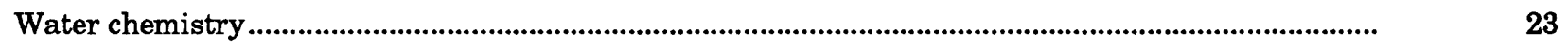

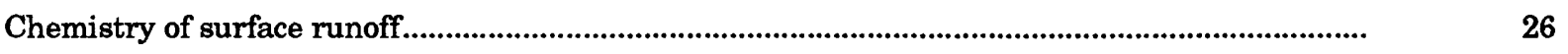

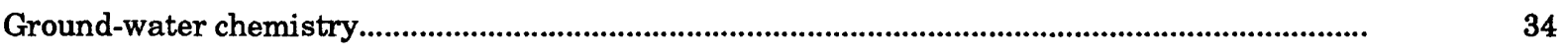

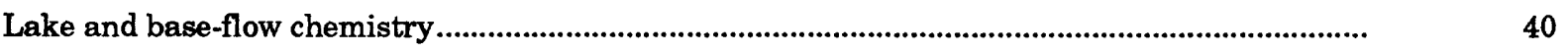

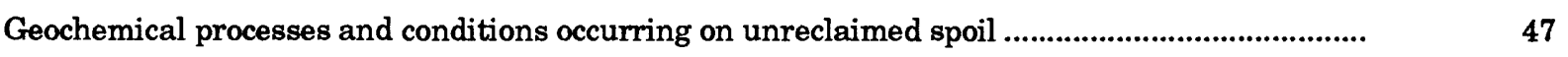

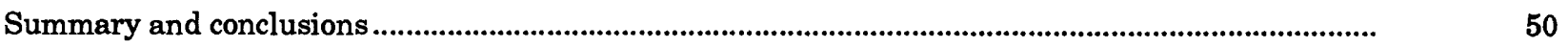

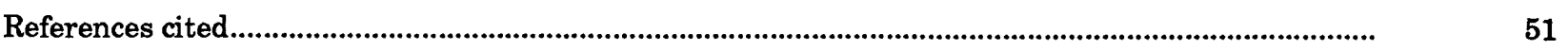




\section{ILUSTRATIONS}

\section{Page}

Figure 1. Map showing location of study area, surface features, and surface-water-datacollection sites

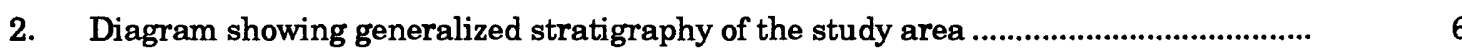

3. Map showing areas of internal drainage and infrequent outflow in the Horn Branch basin

4. Generalized hydrogeologic section $\mathbf{A}-\mathbf{A}^{\prime}$

5. Map showing altitude of water table in spoil

6. Map showing altitude of the undisturbed rock below spoil

7-11. Maps showing discharge, $\mathrm{pH}$, and specific conductance measurements made:

7. April 17-19, 1985

8. September 10-13, 1985 .

9. April 21-25, 1986

10. July 9,1986

11. July 31,1986

12-14. Graphs showing:

12. Two-year water budget for the Horn Branch basin

13. Recession of streamflow in the Horn Branch basin from June 29, 1984, to September 22, 1986

14. Decrease in $\mathrm{pH}$ value of 213 milliliters of water from lake $\mathrm{LN}$ with the addition of surface spoil

15-17. Graphs showing daily rainfall and daily mean discharge, specific conductance, and $\mathrm{pH}$ at site $\mathrm{Q1}$ :

15. July 1 through December 15, 1984

16. March 20, 1985, through February 1,1986

17. March 20 through October 10,1986 ..

18. Map showing $\mathrm{pH}$ value of selected shallow lakes in mined area

19. Map showing $\mathrm{pH}$ value of deep lakes, September 1984 


\section{ILLUSTRATIONS--Continued}

\section{Page}

20. Pattern plots of mean concentrations of selected constituents in storm runoff, perched lakes, ground water, shallow ground-water-supplied lakes, deep ground-water-supplied lakes, and two types of surface outflow leaving the

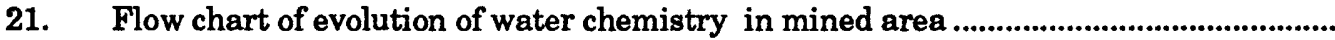




\section{TABLES}

Page

Table 1. Comparison of peak discharges from a mined basin and two unmined basins in west-central Missouri and east-central Kansas.

2. Volume of surface outflow and rainfall on a mined basin and two unmined basins in Pennsylvanian rock in west-central Missouri and east-central Kansas from September 7, 1984, through September 6, 1986

3. Physical characteristics of selected lakes in spoil areas during base-flow conditions...

4. Average daily declines of water levels in recharge lakes during nonrunoff periods 2 to 15 days between May and November 1985 and between March and September 1986

5. Analyses of samples collected from surface runoff on spoil, May 13, 1985.

6. Analyses of samples collected from perched recharge lakes on spoil with no surface outflow immediately after 2.86 inches of rain, May 13,1985

7. Analyses of samples collected from surface outflows of larger spoil lakes and outflows leaving the study area immediately after 2.86 inches of rain, May 13, 1985

8. Characteristics of major dissolved constituents in water from wells completed in spoil

9. $\mathrm{pH}$ values and saturation indices of ground-water samples.

10. Analyses of samples collected from wells completed in spoil.

11. Analyses of samples collected from springs discharging from spoil

12. Analyses of samples from selected shallow lakes perched on spoil during dry periods.

13. Analyses of samples collected from lakes in saturated contact with the groundwater system in the spoil 


\section{CONVERSION FACTORS AND VERTICAL DATUM}

\section{Multiply}

acre

acre-foot

cubic foot per second per square mile

cubic foot per second

foot

inch

mile

square mile

gallon per minute

foot per day
By

0.4047

0.001233

0.01093

0.02832

0.3048

25.4

1.609

2.590

0.06308

0.3048

\section{To obtain}

hectare

cubic hectometer

cubic meter per second per square kilometer

cubic meter per second

meter

millimeter

kilometer

square kilometer

liter per second

meter per second

Temperature in degrees Celsius $\left({ }^{\circ} \mathrm{C}\right)$ can be converted to degrees Fahrenheit $\left({ }^{\circ} \mathrm{F}\right)$ by using the following equation:

$$
{ }^{\circ} \mathrm{F}=9 / 5^{\circ} \mathrm{C}+32 .
$$

Sea level: In this report "sea level" refers to the National Geodetic Vertical Datum of 1929 (NGVD of 1929)--a geodetic datum derived from a general adjustment of the first-order level nets of both the United States and Canada, formerly called Sea Level Datum of 1929. 


\title{
HYDROLOGY AND WATER CHEMISTRY OF AN ABANDONED SURFACE COAL MINE, SOUTHWESTERN HENRY COUNTY, MISSOURI--1984-86
}

\author{
By \\ Dale W. Blevins
}

\begin{abstract}
The 2,400 acres of abandoned surface-mined land northwest of Montrose, Missouri, contained more than 100 lakes and 1,200 acres of barren, acidic spoil. More than one-half of the lakes had pH values less than 4.0. Seventyseven percent of the Horn Branch basin has been mined and drains most of the acidic spoil.

Ground water in the spoil had a water-table surface and was bounded on the bottom and sides by Pennsylvanian rocks of low permeability. The sides of the spoil aquifer usually were marked by linear, last-cut lakes that fully penetrated the aquifer and received ground-water discharge. The spoil aquifer averaged 30 feet thick. The direction of flow was controlled by the location and altitude of lakes that discharged to or received recharge from ground water.

Overland runoff from bare mine spoil and fly ash had $p H$ values between 2.9 and 3.5. Small values of $p H$ were caused by flushing of the products of pyrite oxidation that occurs between storms. Two samples of runoff from revegetated mine spoil had $p H$ values 2 to 3 units higher than runoff from bare spoil. Calcium and sulfate concentrations in runoff usually totaled a few hundred milligrams per liter, indicating gypsum quickly dissolved in runoff. The $\mathrm{pH}$ value of streamflow leaving the mine indicated only minimal effects from acidic overland runoff because the large quantity of near-neutral lake water from deep lakes moderated fluctuations in water chemistry. Also, large areas of internal drainage prevented much acidic runoff from entering streams.
\end{abstract}

Acidic ground-water recharge near the spoil surface became depleted in oxygen and dissolved calcite at depth. The lack of oxygen to drive pyrite oxidation and the bonding of hydrogen ions to carbonate anions increased the $p H$. The $p H$ of ground water was between 5.7 and 6.8 except in fly ash and near some acidic recharge lakes where the $p H$ decreased to less than 4.0 during wet weather. Reducing conditions in the spoil caused iron concentrations to average 93 milligrams per liter in sampled wells. Computer models calculating ionic speciation and mineral equilibria were used with data from water analyses to indicate probable chemical reactions occurring in the spoil. Gypsum, ferrihydrite, and potassium jarosite were usually near or above saturation in ground water. Calcite and rhodochrosite were near or above saturation when the $\mathrm{pH}$ was greater than 6.4.

Lakes with insignificant dry-weather inflows and with average depths less than 8 feet had $p H$ values between 2.8 and 4.3. The pH of lakes averaging more than 9 feet deep was greater than 6.0. Shallow lakes usually were perched above the water table between ridges of spoil. However, a few shallow lakes intercepted the water table and received ground-water discharge with high iron concentrations. Water in these lakes became acidified to a pH between 2.7 and 3.4 upon exposure to the atmosphere and produced sustained base flows that decreased pH values downstream. The $\mathrm{pH}$ of acidic water was seldom less than 3.0 because of stability of ferrous iron in solution and the buffering capacity of sulfate-rich water at low pH values. The deeper lakes were near neutral because of substantial quantities of near-neutral surface runoff from unmined or topsoiled areas and because of ground-water contributions with lower iron to bicarbonate ratios. The $p H$ value of base flow in Horn Branch, where it left the mine, was decreased to 3.5 during the dry summer months by sustained outflow from the shallow, ground-watersupplied lakes. During the rest of the year, outflows from near-neutral lakes were large enough to dominate the water chemistry in the downstream reaches of Horn Branch.

A substantial part of the mined area had internal drainage (20 percent of the Horn Branch basin) caused by spoil ridges that blocked drainage paths. Consequently, unit peak discharges were about 40 percent less and total surface-outflow volumes were about 15 percent less from the Horn Branch basin than from two larger unmined 
basins. Forty-seven percent of the runoff was caused by precipitation directly falling on lakes having outflow. Lakes receiving runoff in areas of internal drainage supplied most of the recharge to ground water and increased baseflow volumes.

\section{INTRODUCTION}

Surface coal mining in the area around Montrose, Missouri, has supplied fuel for the Montrose Power Plant since 1956 (Kansas City Power and Light, written commun., 1954). Major reclamation of surface mines began about 1972, but by 1987 most of the mined lands northwest of Montrose remained unreclaimed. The mined area contained more than 1,200 acres of barren spoil, 100 lakes, and several streams, many of which are acidic. Prereclamation data and understanding of water chemistry were needed to determine the effects of reclamation activities on water quality in the mine. This study, conducted in cooperation with the Missouri Department of Natural Resources, Land Reclamation Commission, was intended to provide the data necessary for reclamation activities in the study area.

\section{Purpose and Scope}

The purpose of this report is to present the results of a hydrologic and water-quality study made in westcentral Missouri at an abandoned surface coal mine from June 1984 to September 1986. Objectives of the study included quantifying the volume of water in, on, and moving through the spoil and determining the chemical characteristics of and major chemical reactions occurring in water affected by the mine.

\section{Description of Study Area}

The study area consists of about 3,000 acres in west-central Missouri (fig. 1), underlain by Pennsylvanian shale, sandstone, limestone, and coal of the Cherokee Group (fig. 2). From 1956 to 1973, 2,400 acres of the study area were surface mined. In most places, two coal seams, one in the Weir Formation ${ }^{1}$ (Weir-Pittsburg coal member) and a coal seam on the Tebo Formation ${ }^{1}$, were mined, but coal seams in the Fleming and Croweburg Formations ${ }^{1}$ also were removed where they had not been eroded and were thick enough to be economically mined. (Peabody Coal Company maps of Power Mine, Montrose, Missouri). Thirty-three percent of the mined area had been regraded and revegetated as of 1987. Reclaimed areas have smooth topography and usually are covered with grass, whereas the rough unreclaimed areas usually are either barren or forested. Topsoil has been applied to about 20 percent of the regraded areas. About 40 acres between lakes LM and LEE were covered with fly ash from the power plant and have been regraded. This area has no vegetation (fig. 1). Both reclaimed and unreclaimed areas have numerous lakes larger than 2 acres caused by last-cut and haul-road excavations that have filled with water. In addition to these lakes, the unreclaimed areas contain countless smaller bodies of water trapped between ridges of spoil.

The western 1,200 acres of the study area are drained by Horn Branch, and the eastern part of the study area is drained by six smaller streams (fig. 1). However, a large part of the mined area has internal drainage because of ridges of spoil and deep depressions that trap runoff.

\section{Methodology}

Data were collected at several sites to determine the hydrology of the study area. Streamflow was continuously monitored at the two largest outflow sites (sites G1 and G3, fig. 1) and at one large tributary (site G2). Weirs, rated with discharge measurements, were used as controls at lake outlets at all three gaging stations. Rainfall was continuously monitored at one site in the study area (site RG, fig. 1). Daily precipitation data from Peabody Coal Company, Montrose (collected $2 \mathrm{mi}$ (miles) from the study area) and from the National Weather Service station near Appleton City (7 mi from the study area; fig. 1) were used during periods of missing record. The water level of one lake (L17) with no surface outflow was continuously monitored to measure evaporation, seepage losses, and runoff into the lake (site G4). The water levels of several lakes were monitored weekly to obtain estimates of these processes. Synoptic discharge measurements were made during dry periods to locate the larger springs and ground-water outflows. Although 33 wells were drilled into spoil, only 25 of the wells penetrated the water table. These wells were used to determine hydraulic heads, and water samples for chemical

\footnotetext{
${ }^{1}$ Unit follows the usage of Missouri Division of Geology and Land Survey.
} 
analysis were collected from 11 of the wells. The wells were cased with 3-in. (inch) diameter plastic pipe, slotted in the bottom $5 \mathrm{ft}$ (feet). Water levels in wells were measured at 1 to 3 week intervals in 18 of the wells, using a steel tape. Altitudes were determined by land survey from benchmarks set by a contractor for the Missouri Land Reclamation Commission during reclamation work.

The depths of 28 lakes were measured with a depth finder during bathometric surveys done between September 17 and October 4,1984. Surface areas were measured with a planimeter and combined with the depth data to approximate the volume of each lake. Profiles of $\mathrm{pH}$ and specific conductance with depth were determined at one to five locations in each lake, depending on the size and shape of the lake. Measurements were made at 3 $\mathrm{ft}$ below the surface, 1 to $3 \mathrm{ft}$ above the bottom, and at intermediate depths if the maximum depth of the lake was more than $10 \mathrm{ft}$.

Surface- and ground-water samples were collected to identify hydrochemical processes and establish baseline water-quality characteristics before reclamation. Temperature, specific conductance, and $\mathrm{pH}$ were continuously monitored at sites Q1, Q2, and Q3 to determine fluctuations of these properties with flow and season. Two sets of water samples were collected synoptically at 25 surface-water sites during high- and low-base flows and 11 wells. Runoff and lake outflows were sampled at 24 sites during one storm on May 13, 1985. Stream samples were collected from the midpoint of the stream cross section in polyethylene bottles. Ground water from wells that would not sustain pumpage of about $0.5 \mathrm{gal} / \mathrm{min}$ (gallon per minute) was sampled several minutes after all water from the well bore was removed by pumping. Larger yielding wells were sampled several minutes after the temperature and specific conductance of the pumped water became constant. Ground-water samples were collected in a plastic churn splitter and sent to the laboratory in polyethylene bottles.

Laboratory analyses of water samples were by the U.S. Geological Survey Laboratory in Arvada, Colorado, in accordance with procedures outlined by Skougstad and others (1979). All analyzed constituents were in the dissolved phase and were determined from water samples that were filtered at the time of sampling through a 0.10 $\mu \mathrm{m}$ (micrometer) filter in a polyvinyl chloride chamber using a peristaltic pump as the pressure source. Water samples analyzed for metals were acidified in the field with double-distilled, laboratory-grade nitric acid to a pH value of less than 3.0. Specific-conductance values were measured using a portable conductivity meter with temperature compensation designed to express readings in microsiemens per centimeter at $25^{\circ} \mathrm{Celsius}$. The electrometric method was used to measure $\mathrm{pH}$ values and titrate alkalinity in the field.

Acidity is defined in this report as the capacity of a solution to react with hydroxyl ions and was determined by endpoint titration to a $\mathrm{pH}$ of 8.3. Alkalinity is similarly defined as the capacity of a solution to react with hydrogen ions and was determined by incremental titrations made to the inflection point of the titration curve at a $\mathrm{pH}$ of about 4.5, where nearly all the carbonate is in the form of carbonic acid $\left(\mathrm{H}_{2} \mathrm{CO}_{3}\right)$.

Computations of saturation indices were done using the chemical equations and equilibrium constants, in a computer algorithm called WATEQF (Plummer and others, 1976). A modification of WATEQF that considers several minerals commonly associated with mine drainage (WATEQ4F) by Ball and Nordstrom (1987) was used for this study.

\section{Acknowledoments}

Appreciation is extended to the Peabody Coal Company staff at the Power Mine for access to their property and to various types of data from their files. Also, land owners near the mine were cooperative in permitting measurement of water levels in their wells. Support of this study by the U.S. Department of Interior, Office of Surface Mining Reclamation and Enforcement also is acknowledged. However, the contents of this publication do not necessarily reflect the views and policies of this agency.

\section{HYDROLOGY}

\section{Surface-Water Movement}

Surface-water drainage in the mined areas is primarily from lake to lake by connecting streams (fig. 1). A significant part of the mined area (20 percent of the Horn Branch basin, fig. 3) did not contribute runoff to streams leaving the study area. Ridges of spoil blocked surface drainage and impounded water in the low places between 

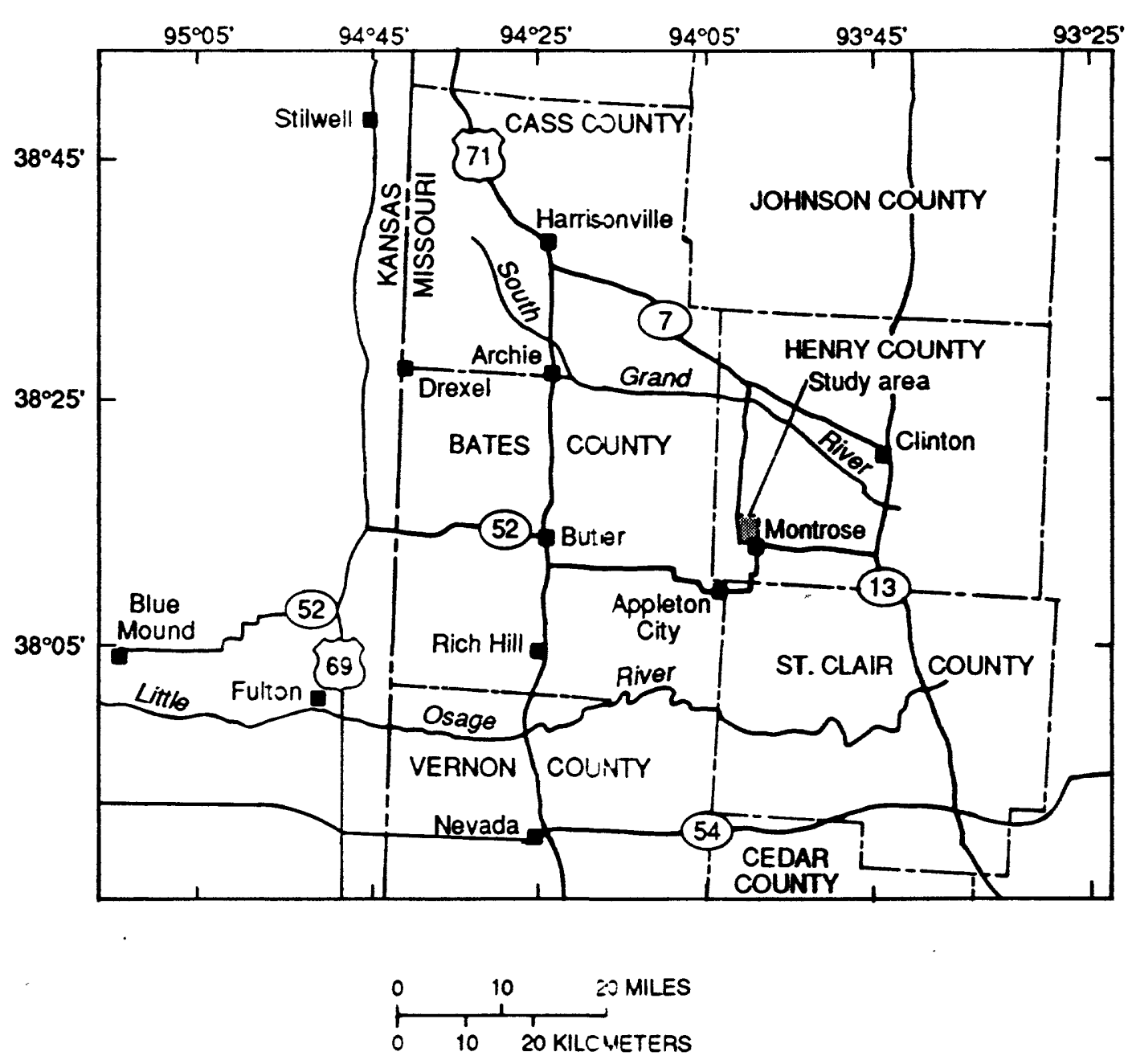

EXPLANATION

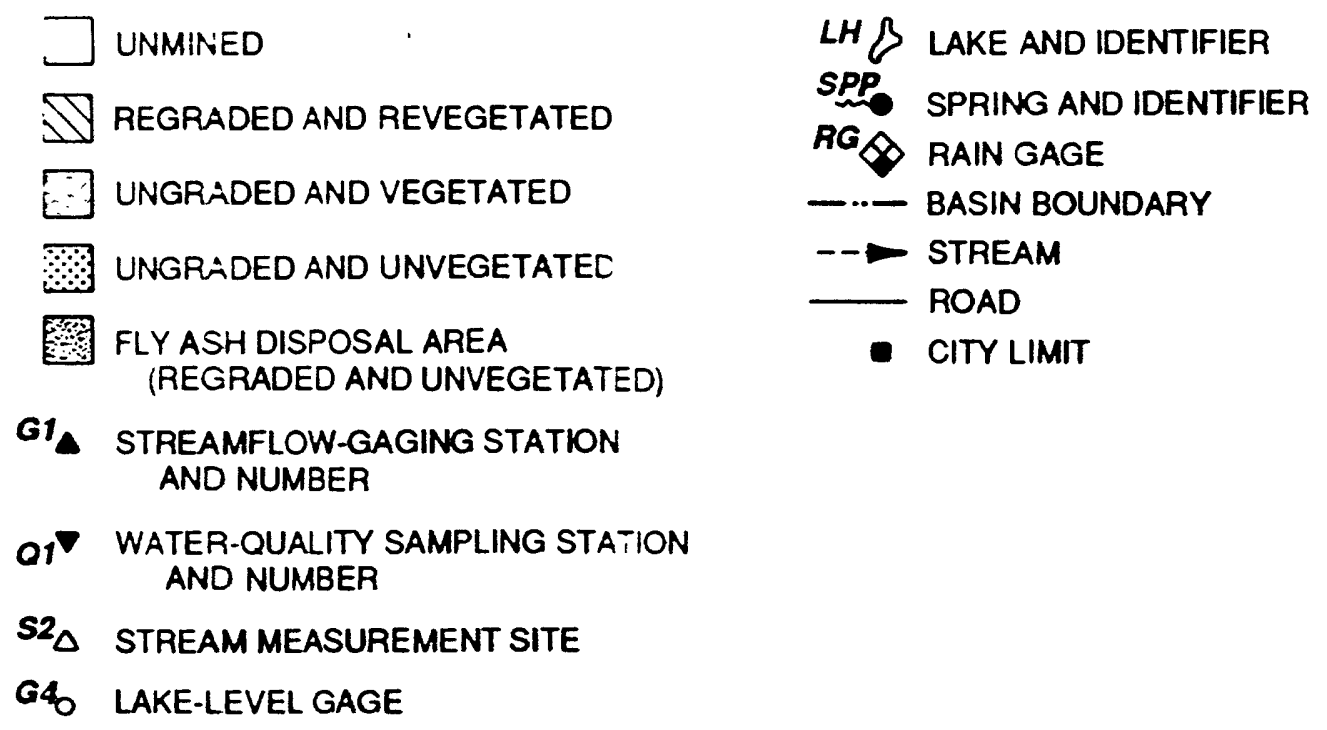

Figure 1.--Location of study area, surface features, and surface-water-data-collection sites. 


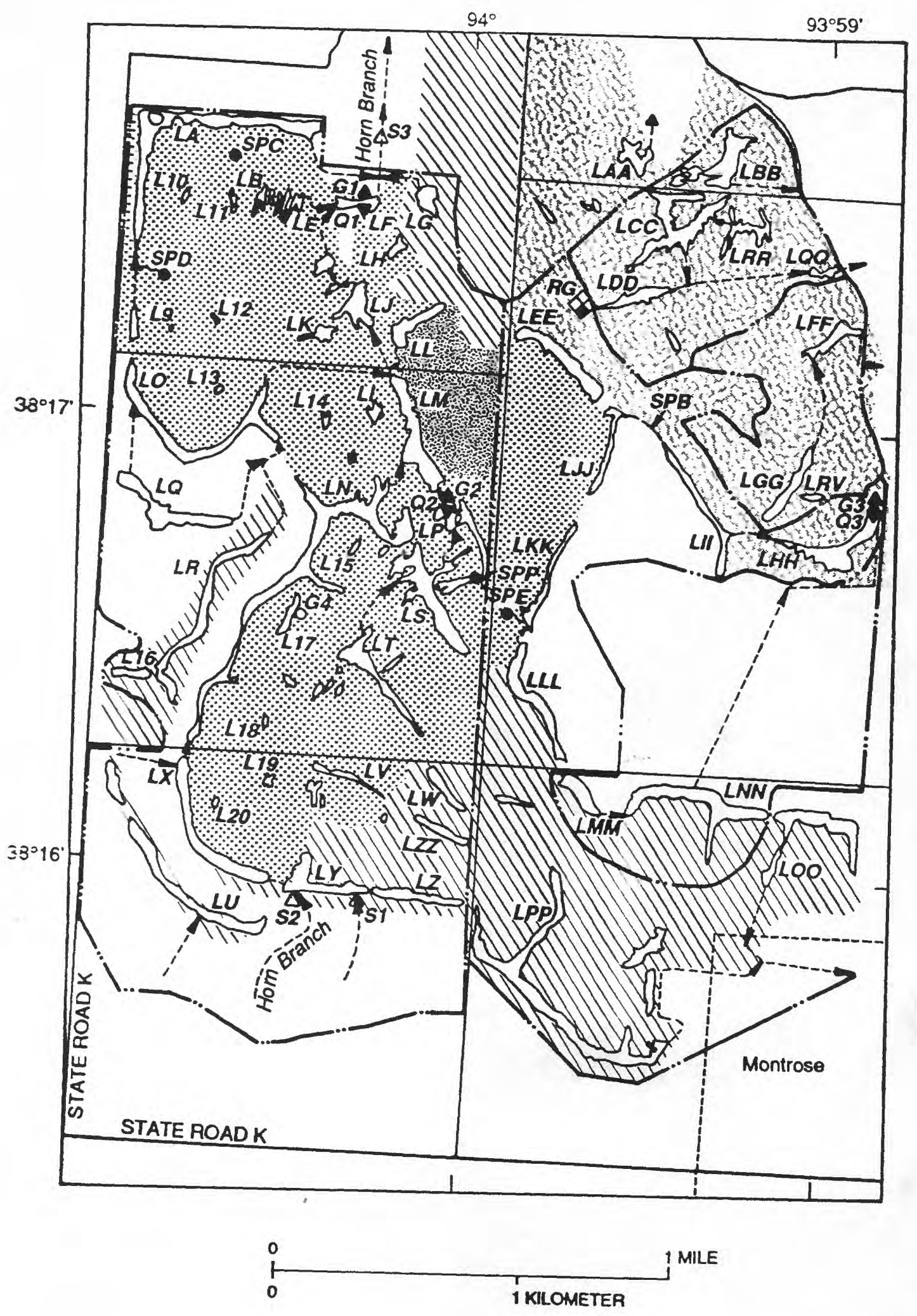

Figure 1.-Location of study area, surface features, and surface-water-data collection sites--Continued. 


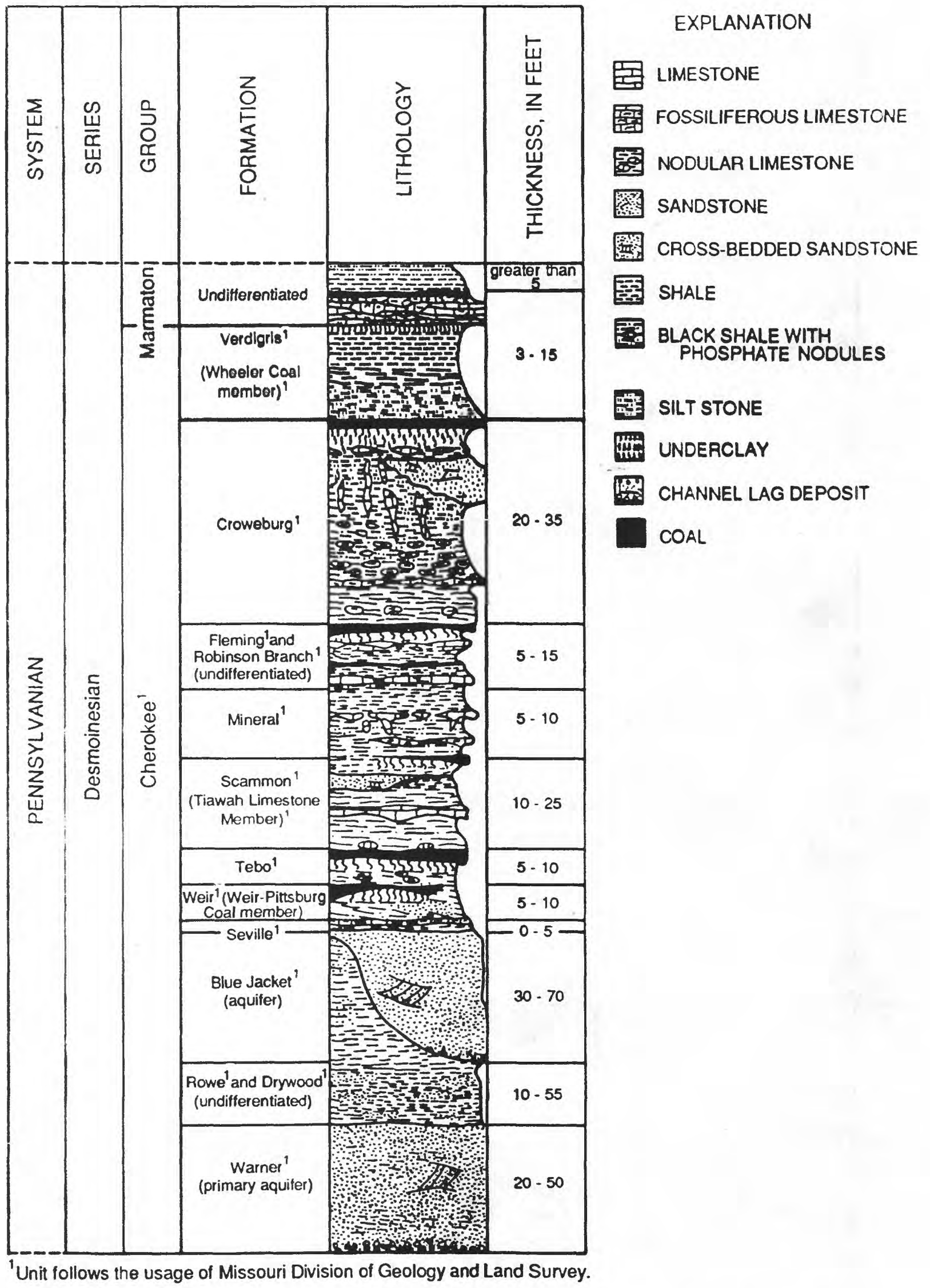

Figure 2.--Generalized stratigraphy of the study area (nomemclature modified from Koenig, 1961). 


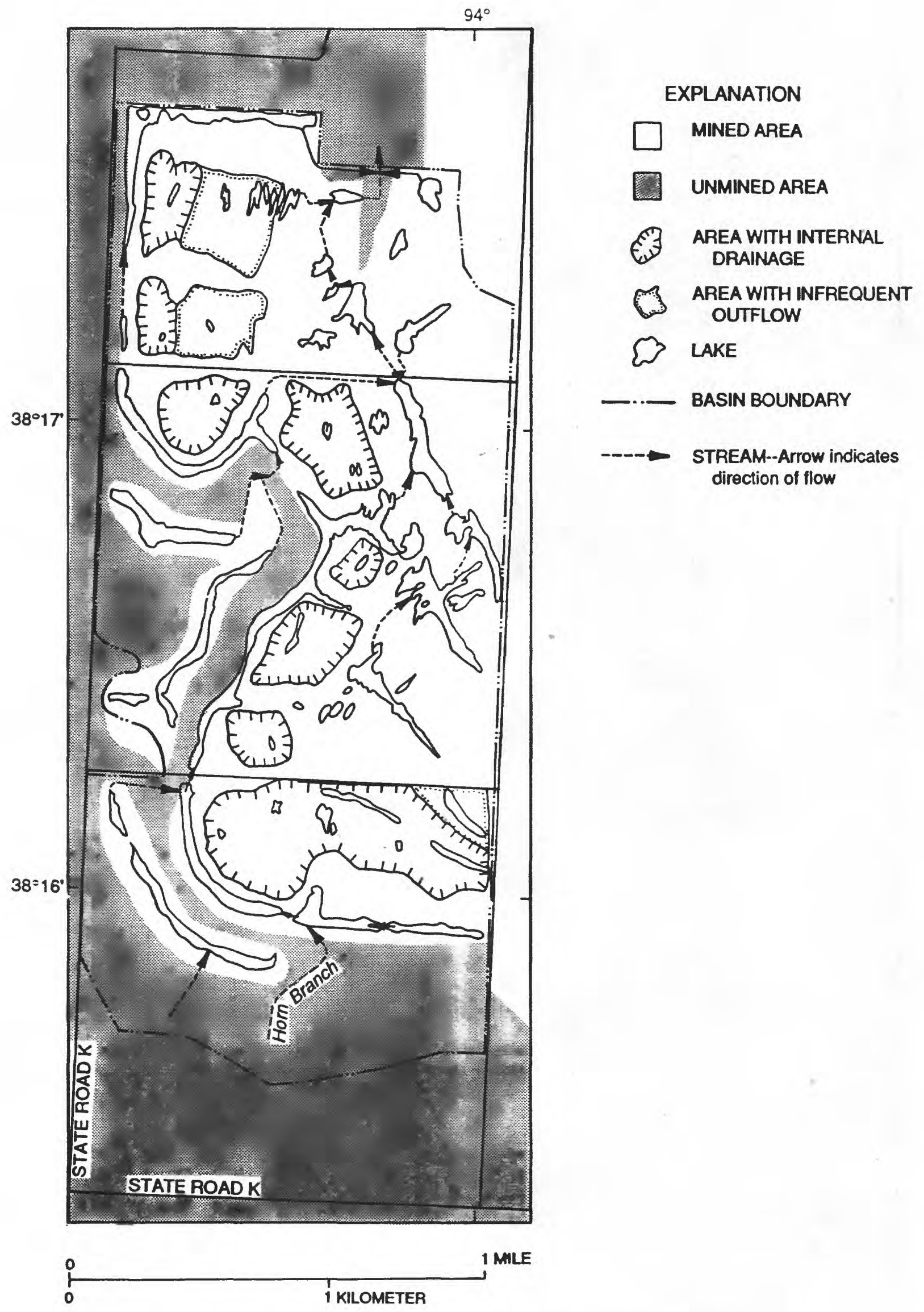

Figure 3.--Areas of internal drainage and infrequent outflow in the Horn Branch basin. 


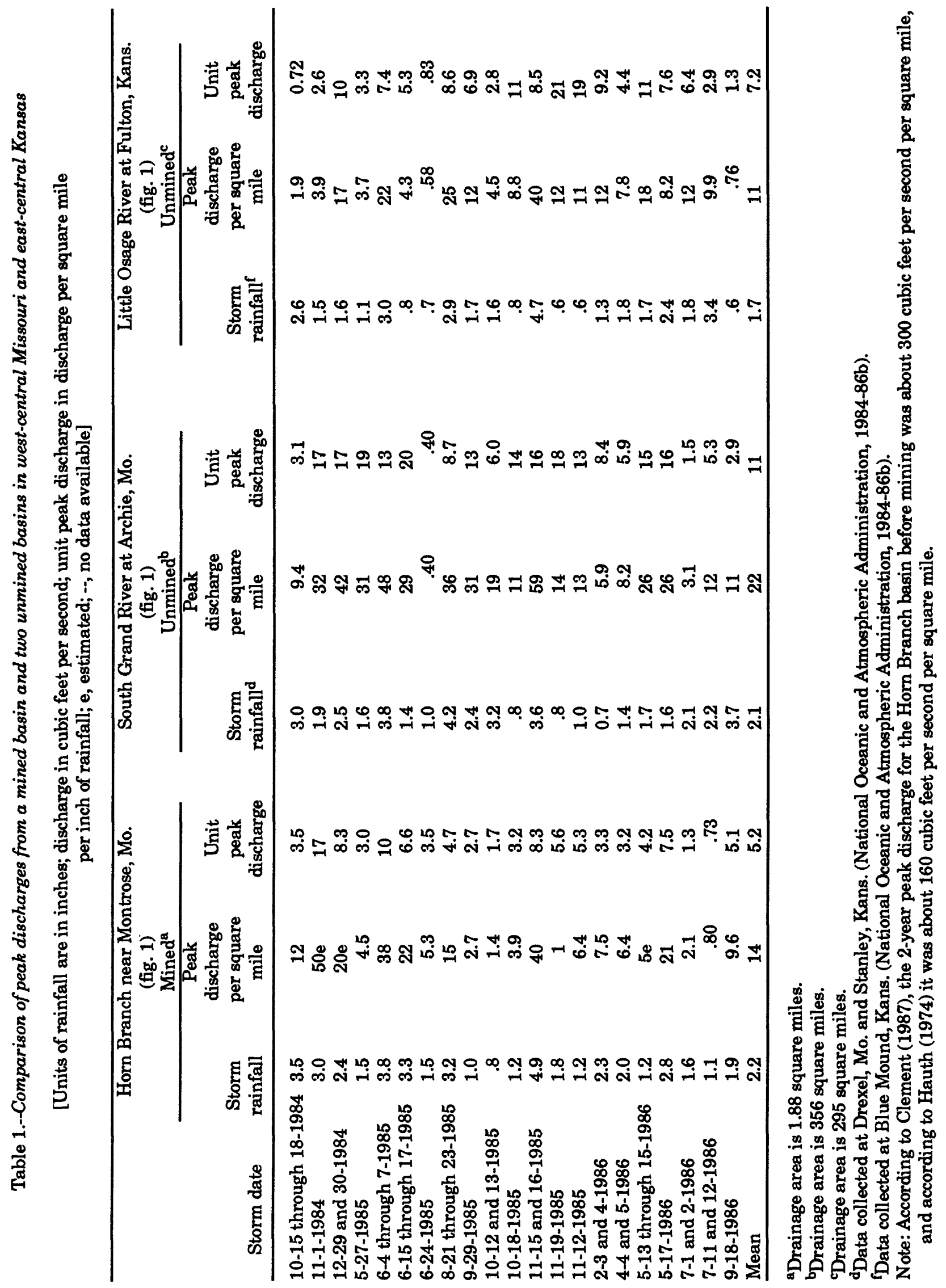


ridges. This internal drainage caused areas of unreclaimed spoil to have smaller peak discharges and runoff volumes than unmined areas. Unit peak discharges (discharge per drainage area per inch of rainfall) from the Horn Branch basin (60 percent unreclaimed, 23 percent unmined, and 17 percent regraded) averaged 53 and 28 percent less than the unit peak discharges from two larger unmined basins in the same physiographic region during 1984-86 (table 1). If the total volumes of surface runoff are examined on a per-area basis, the percentage of rainfall leaving the Horn Branch basin as surface outflow was 22 percent less than the South Grand basin and 11 percent less than the Little Osage basin (table 2).

Table 2.--Volume of surface outflow and rainfall on a mined basin and two unmined basins having surficial Pennsylvanian rock in west-central Missouri and east-central Kansas from September 7, 1984, through September 6, 1986

\begin{tabular}{|c|c|c|c|c|c|}
\hline Gaging station & $\begin{array}{c}\text { Rainfall }^{\mathbf{a}} \\
\text { (inches) }\end{array}$ & $\begin{array}{r}\text { Sur } \\
\text { Inches }^{\mathbf{a}} \\
\end{array}$ & $\begin{array}{l}\text { utflow } \\
\text { Percentage } \\
\text { of rainfall }\end{array}$ & $\begin{array}{l}\text { Approximate } \\
\text { percentage } \\
\text { lost to } \\
\text { evapotrans- } \\
\text { piration } \\
\end{array}$ & $\begin{array}{c}\text { Drainage } \\
\text { area } \\
\text { (square } \\
\text { miles) }\end{array}$ \\
\hline $\begin{array}{l}\text { Horn Branch near } \\
\text { Montrose, Mo. } \\
\text { (fig. 1, site G1) }\end{array}$ & 99 & 32 & 32 & 68 & 1.88 \\
\hline $\begin{array}{l}\text { South Grand River } \\
\text { at Archie, Mo. }\end{array}$ & $c_{100}$ & 41 & 41 & 59 & 365 \\
\hline $\begin{array}{l}\text { Little Osage River } \\
\text { at Fulton, Kans. }\end{array}$ & d91 & 33 & 36 & 64 & 295 \\
\hline
\end{tabular}

aVolume expressed as equivalent depth over the entire basin.

bAssuming negligible gains or losses to regional ground-water system and to ground-water storage.

'Data collected at Drexel, Mo. and Stilwell, Kans. (National Oceanic and Atmospheric Administration, 1984-86a). dData collected at Blue Mound, Kans. (National Oceanic and Atmospheric Administration 1984-86a).

Lakes receiving runoff from areas of internal drainage were filling with sediment during this study, especially where spoil was unvegetated and erosion was rapid. Some areas of infrequent outflow contributed runoff only after a large storage capacity was filled. These areas generally are only temporary features because erosion tends to quickly cut through barren spoil ridges when they are overtopped by streamflow. At the end of the study (September 1986), an extremely rare rainfall occurred in which 17 in. of rain fell in 5 days. This event occurred after $6 \mathrm{in}$. of rain in the preceding week had saturated the soil. The large volume of runoff generated by this rain completely filled many between-spoil-pile lakes, and they overflowed into outside drainages for the first time since mining ended. The erosion and sedimentation caused by this flood decreased the capacity of the area to retain runoff and hastened the time when many lakes will no longer be able to retain runoff. In fact, 60 acres that had internal drainage in the Horn Branch basin at the beginning of this study presently (1987) retain little, if any, runoff. Water trapped behind spoil ridges either evaporated or seeped through lake bottoms into ground-water storage and eventually increased base flow.

\section{Ground-Water Movement}

The rocks near Montrose predominately are shales (fig. 2) of low permeability. More permeable soil and weathered rock less than $20 \mathrm{ft}$ from the surface lie atop the shales and constitute a small, but historically significant, aquifer in the area. During a survey of 16 private wells within $1 \mathrm{mi}$ of the study area, it was discovered that most farms had used large diameter wells less than $25 \mathrm{ft}$ deep in the past, although nearly all farms and the city of Montrose presently (1987) use sandstone aquifers between 200 and $350 \mathrm{ft}$ deep for their supplies. Observation of active, nearby mine pits indicated that nearly all of the rocks between the two aquifers were unsaturated. Water levels in 5 shallow wells ranged from 2.0 to $11.8 \mathrm{ft}$ below the land surface on April 17-18, 1985 . The remaining 11 wells were drilled into what probably are the Bluejacket and Warner Sandstones (fig. 2). The water levels in these deeper wells ranged from 84.5 to $148.8 \mathrm{ft}$ below the land surface (average depth to water was $108 \mathrm{ft}$ ), indicating artesian pressure in these aquifers. The difference in water levels in the shallow and deep wells indicate an overall downward vertical gradient through the unsaturated zone. The steepness of this gradient and the presence of unsaturated rocks between the near-surface and sandstone aquifers are caused by the low 
permeability of undisturbed rock in this area. However, surface mining generally increases the permeability of the rocks by at least two orders of magnitude (Weiss and Razem, 1984). This relative difference in permeability between spoil and undisturbed rock allows the spoil to be considered a water-table aquifer bounded on the sides and bottom by undisturbed and unsaturated rocks of low permeability that allow only insignificant quantities of leakage.

Lakes were the primary control of water levels in the spoil. They supplied recharge in the topographically high areas and collected ground-water discharge in the low areas (fig. 4). Data from 55 lakes during base-flow conditions are summarized in table 3. Lakes were identified as having net ground-water discharge if they had dry-weather outflow, were supplied by springs in the littoral (near-shore) zone, or had water levels consistently lower than water levels in nearby wells. Lakes identified as having net recharge are those having no or infrequent surface outflow and drainage areas at least twice as large as the lake surface areas or water levels consistently higher than water levels in adjacent wells. Several lakes could not be identified as having net discharge or recharge because of missing outflow and ground-water data. The range of $\mathrm{pH}$ and specific conductance data in table 3 is the range of values measured during a bathometric survey and one to three surface measurements made at various times during the study, except as noted.

The water levels in wells in spoil ridges on opposite sides of 5 shallow lakes (lakes L9, L12, L15, L18, and L19) averaged $11 \mathrm{ft}$ below the bottom of the associated lake. Ground-water levels in wells near another shallow lake (lake L10) were at an altitude similar to that of the lake bottom. These data indicate that most of the shallow lakes between spoil ridges were not in saturated contact with the ground-water system. However, these lakes supplied recharge through the unsaturated zone.

Water-level data from 19 wells and more than 30 lakes in contact with the saturated spoil were used to prepare a water-table map (fig. 5). Ground-water mounds typically represent areas of recharge. Generally, ground-water mounds also were over ridges and domes of undisturbed rock below the spoil (figs. 4-6). The contours of undisturbed rock in figure 6 were based on hundreds of drill logs from Peabody Coal Company (drill logs and mining maps on file at the Power Mine, Montrose). Ground-water mounds typically were below or intersected by topographically high lakes that collected runoff from areas of internal drainage and leaked some of the runoff to the ground-water system. The spoil water flowed toward, and was received by, fully penetrating lakes at the edges of the spoil aquifer. A comparison of 48 grid points evenly spaced over the entire spoil area in figures 5 and 6 indicates the spoil aquifer averaged $30 \mathrm{ft}$ thick with a standard deviation of $9 \mathrm{ft}$. The range of water levels in the wells averaged $3.3 \mathrm{ft}$ or about 11 percent of the aquifer thickness during the 14-month period of monitoring. Fluctuations in water levels closely followed monthly precipitation with lagtimes of 1 to 2 weeks.

Data from three large and two small sets of synoptic discharge measurements made during base flow are displayed in figures 7 to 11 . The largest sources of ground-water discharge to the surface-water system at the time of these measurements were lakes LK, LM, LN, LO, LX, LII, and LLL. For example, in figure 7 the inflow to lake $\mathrm{LN}$ was $0.17 \mathrm{ft}^{3} / \mathrm{s}$ (cubic foot per second) and the outflow was nearly twice as much $\left(0.32 \mathrm{ft}^{3} / \mathrm{s}\right.$ ), indicating lake $\mathrm{LN}$ was a significant source of ground water to Horn Branch in April 1985. Lakes provided base flow to receiving streams if the outflow point and thus the water level of the lake was lower than the water table around the lake. Springs and seeps occurred in littoral zones of some lakes (spring SPP), gullies in spoil (spring SPC), and along haul roads incised below the water table in the surrounding spoil (springs SPB and SPD, fig. 1). Also, where data exist, stream discharges are expressed in figures 7 to 11 as percentages of discharge of the stream to which they contribute flow where that stream leaves the study area (lakes LF and LHH).

\section{Water Budget and Surface-Ground Water Exchange}

A 2-year period beginning September 7, 1984, was used to estimate selected components of the water budget in the Horn Branch basin because of similar base flow conditions at the beginning and end of the period. On September 7, 1984, outflow from the basin measured $0.10 \mathrm{ft}^{3} / \mathrm{s}$ and $2.09 \mathrm{in}$. of rain had fallen in the previous 28 days. On September 6,1986, outflow from the basin measured $0.19 \mathrm{ft}^{3} / \mathrm{s}$, and $3.19 \mathrm{in}$. of rain had fallen in the preceding 28 days. Therefore, the ground-water storage volumes should be similar at the beginning and at the end of the period. This assumption could not be verified with water levels because observation wells were not drilled until 1985. Any small difference in storage volumes is assumed to be negligible compared to the total, 2year volume of outflow from Horn Branch. The total volume of precipitation in the Horn Branch basin during the 2-year period measured 99 in. or 9,900 acre-feet and the total volume of outflow at site G1 was 32 in. or 3,200 acrefeet (fig. 12). Assuming the net loss or gain from the regional ground-water system and the change in storage of 


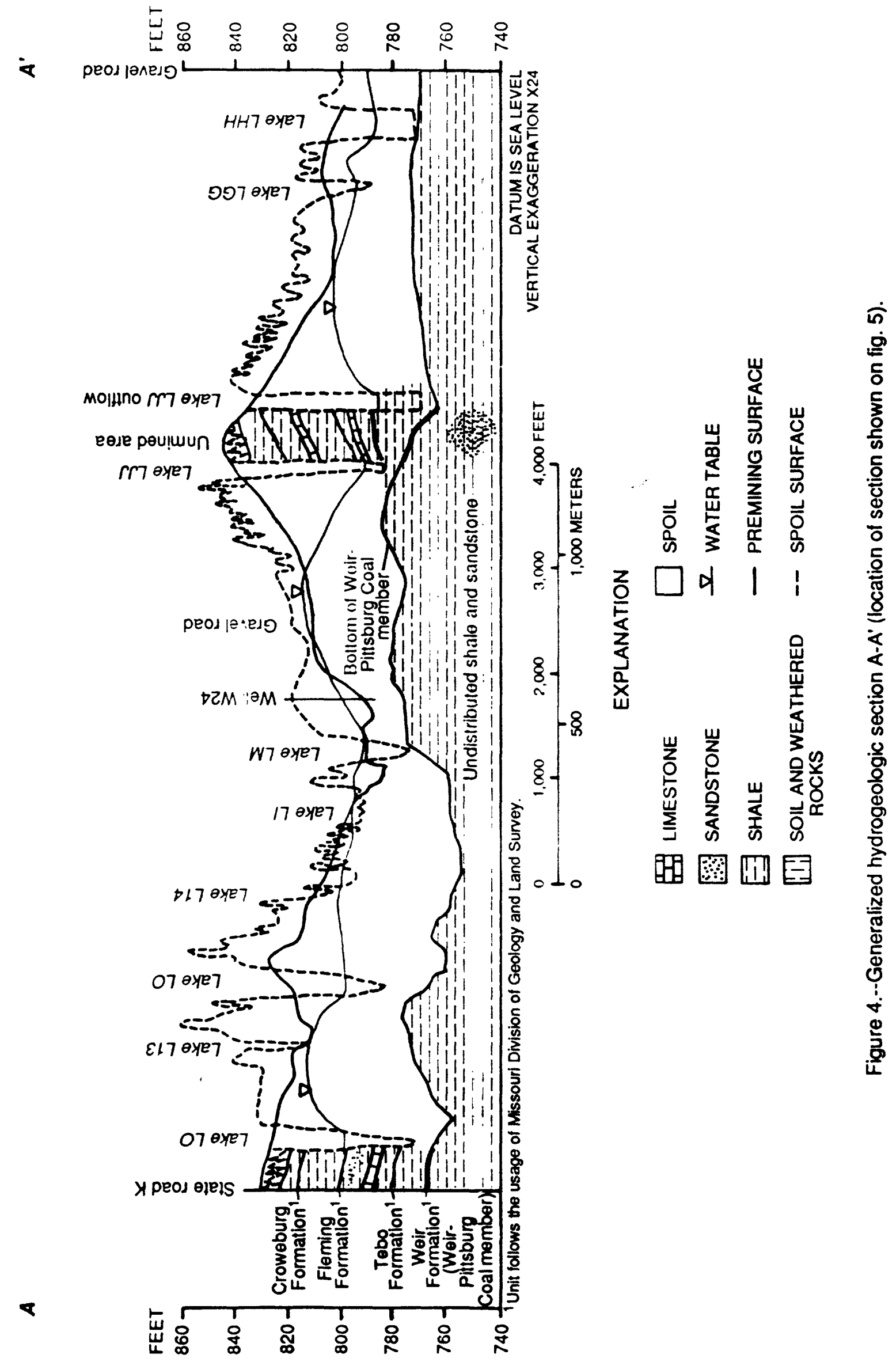




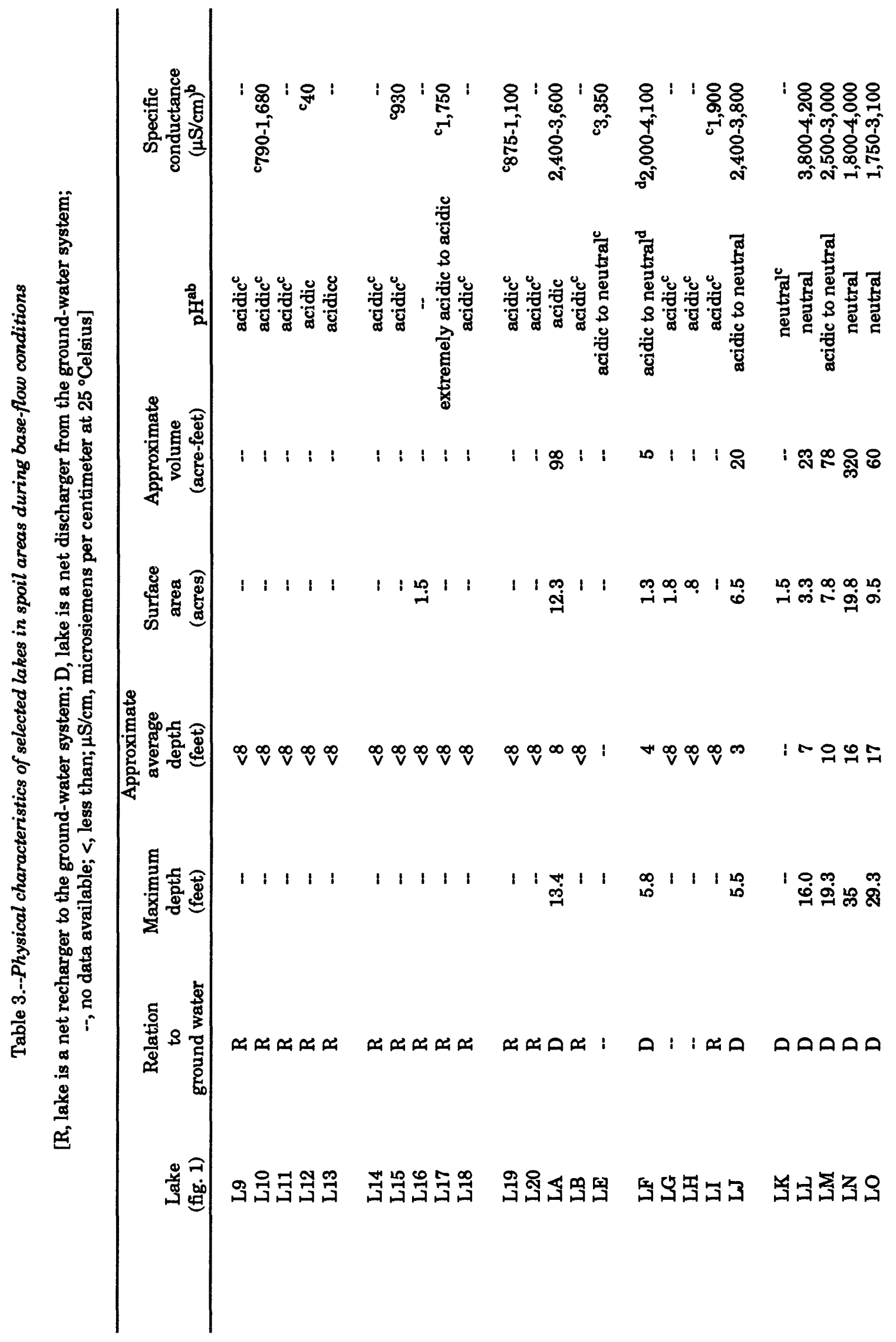




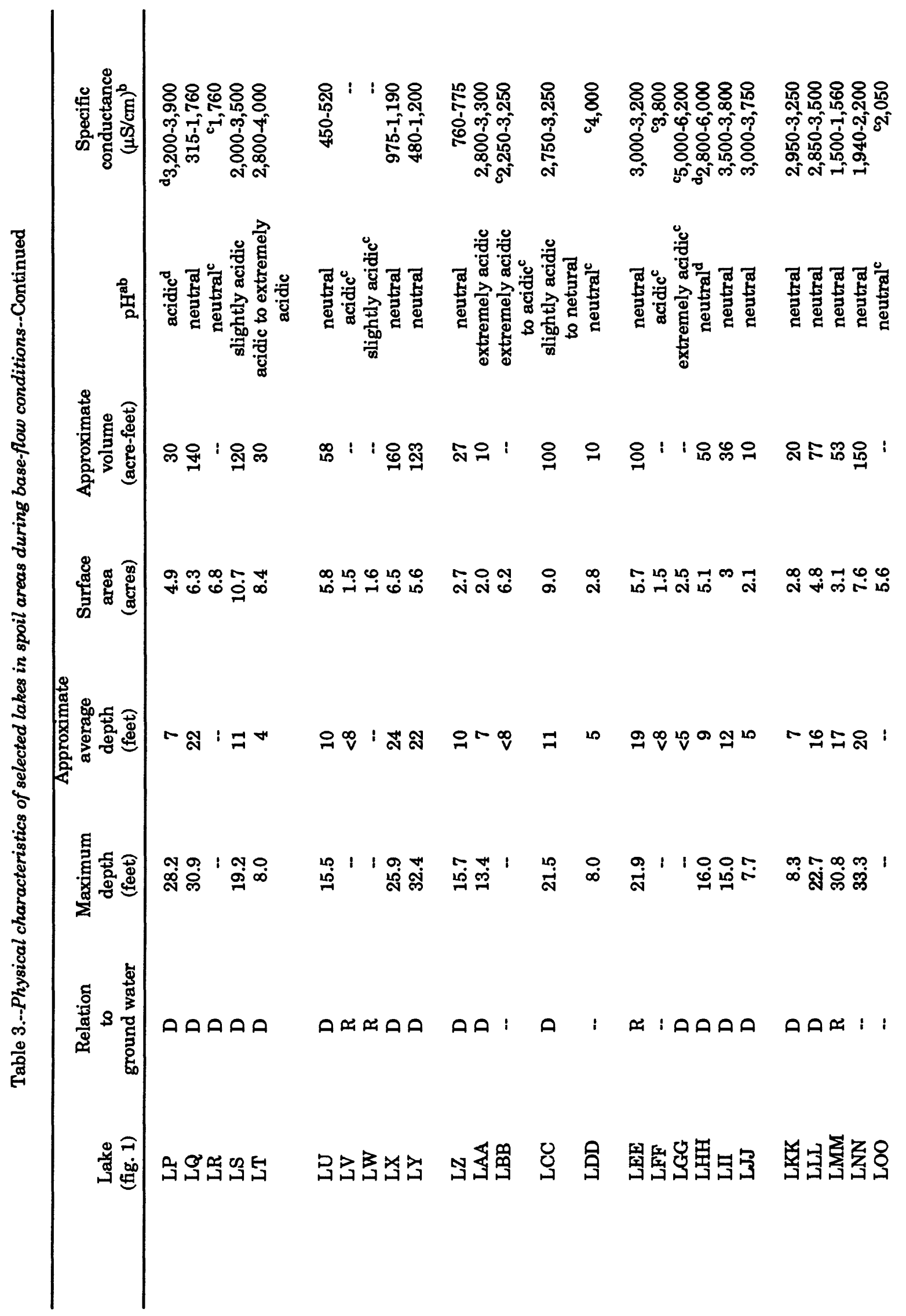




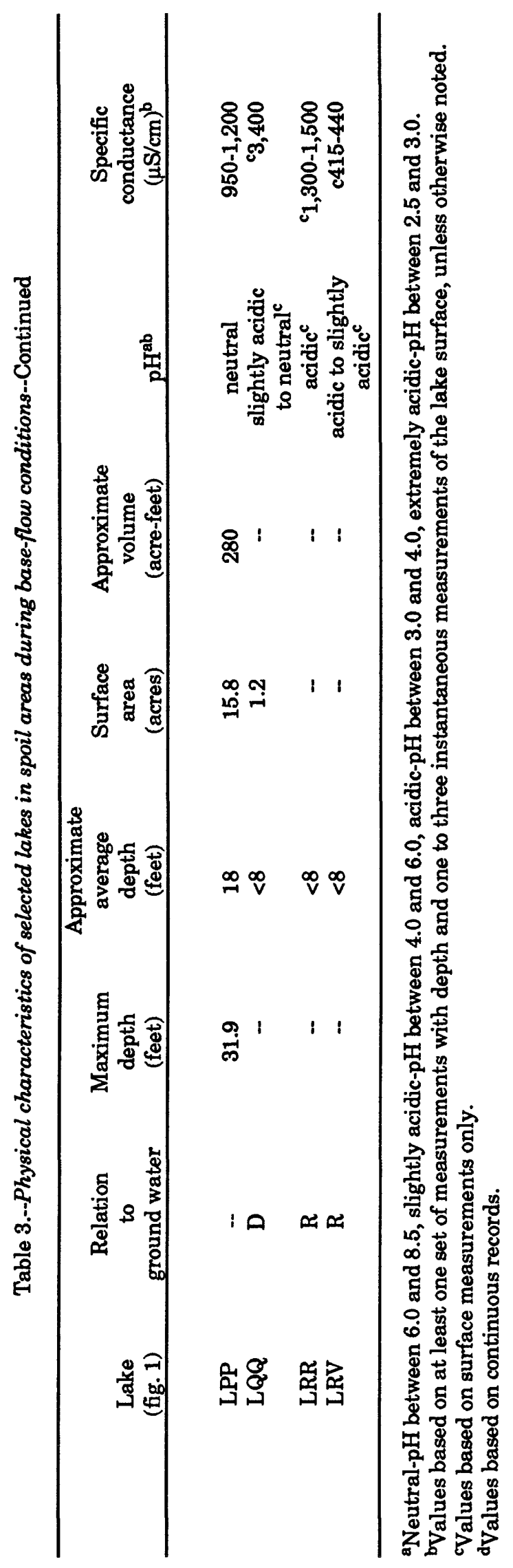




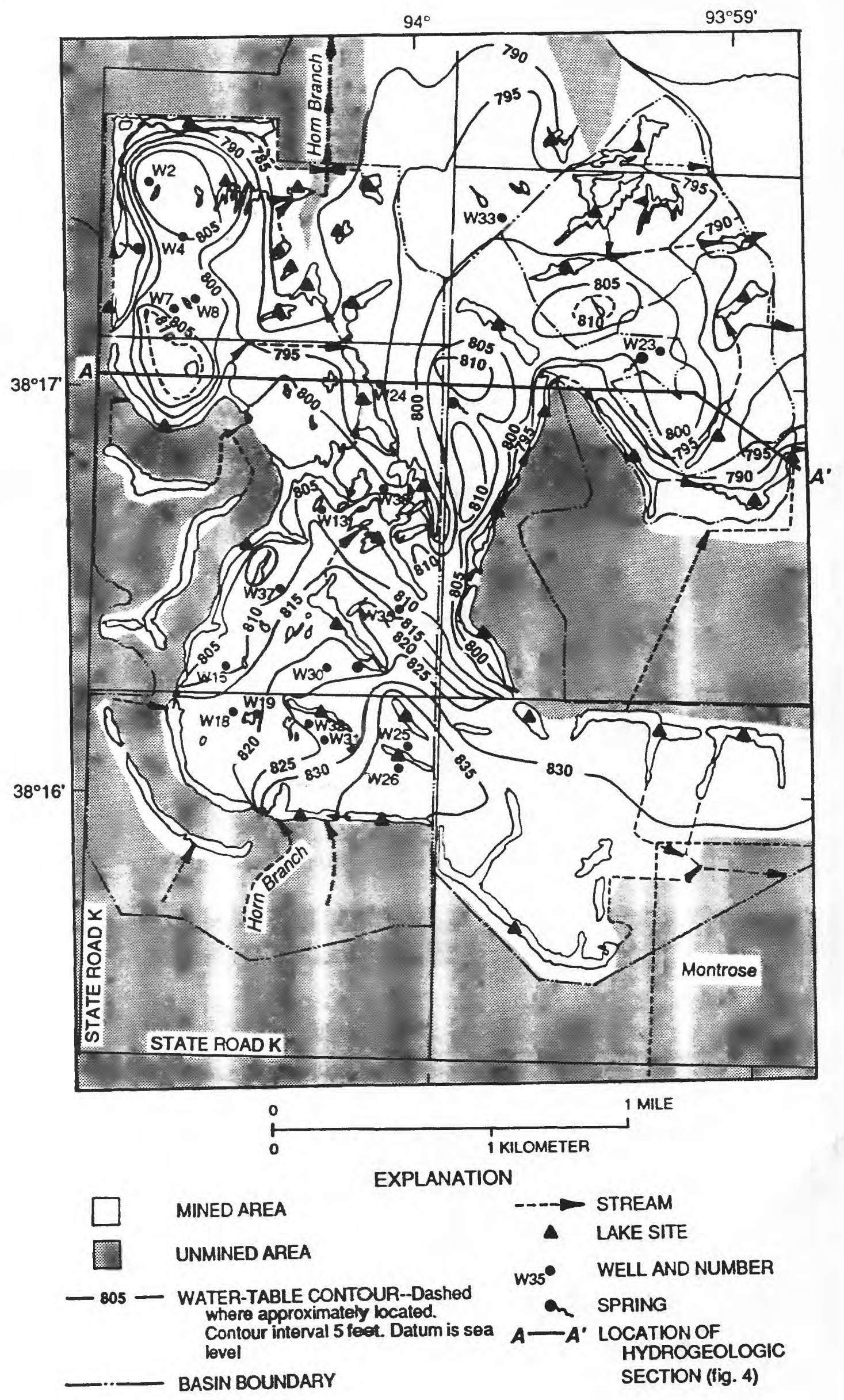

Figure 5.--Altitude of the water table in spoil. 

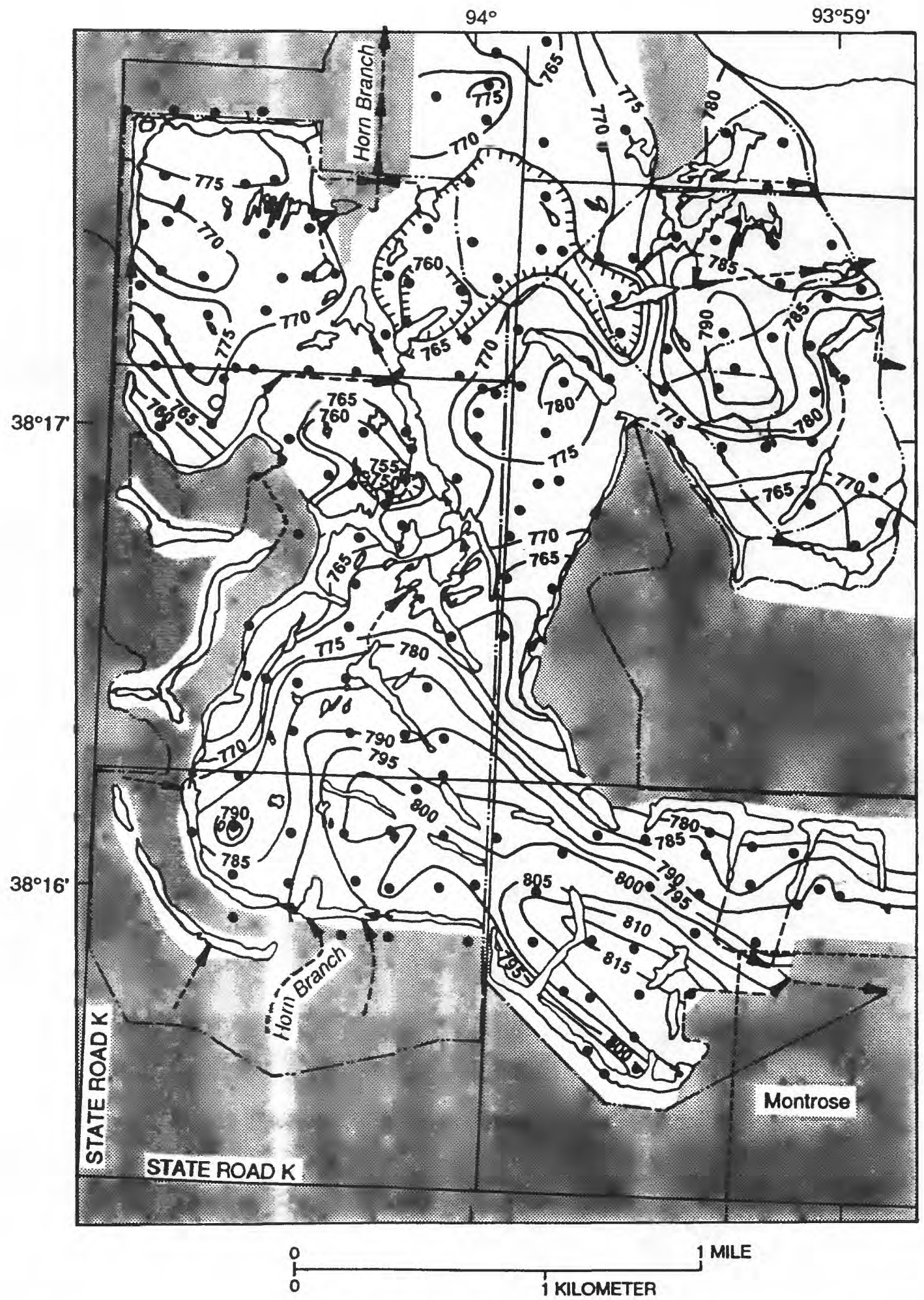

EXPLANATION
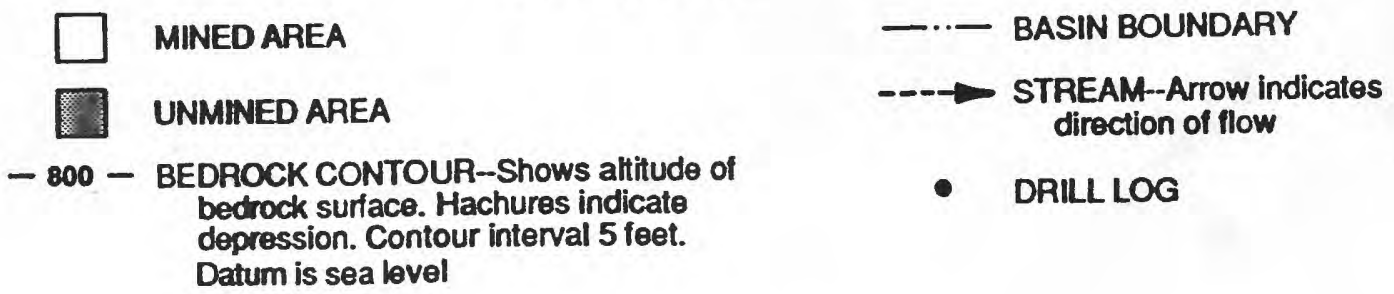

- DRILlLog

Figure 6.--Altitude of the undisturbed rock below spoil. 


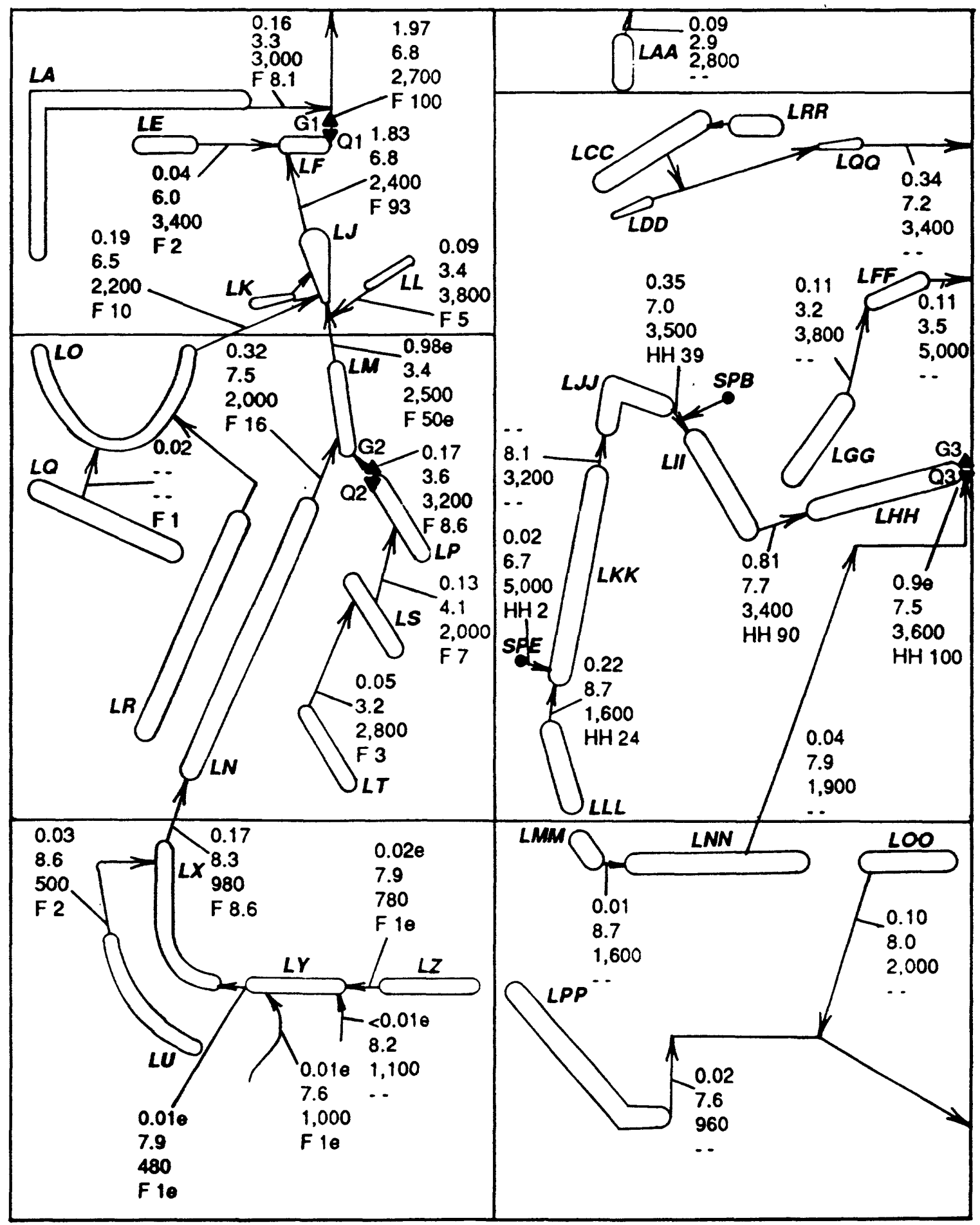

EXPLANATION

LF LAKE AND IDENTIFIER

0.19 LOCATION OF DISCHARGE, PH, AND SPECIFIC CONDUCTANCE MEASUREMENT--TOP

6.5 number is discharge, in cubic feet per second; middle number is pH value; bottom number

2,200 is specific conductance, in microsiemens per centimeter at 25 degrees Celsius; $\theta$ indicates

F 10 an estimated value; - - indicates no data; numbers following $F$ and $H H$ indicate outflow as

SPE percentage of outflow from lakes LF or LHH

Q. SPRING AND IDENTIFIER

$\longrightarrow$ STREAM SEGMENT

$\triangle$ G1 STREAMFLOW-GAGING STATION AND NUMBER

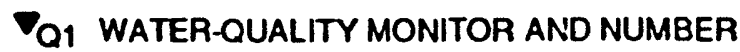

Figure 7.--Discharge, pH, and specific conductance measurements made April 17-19, 1985. 


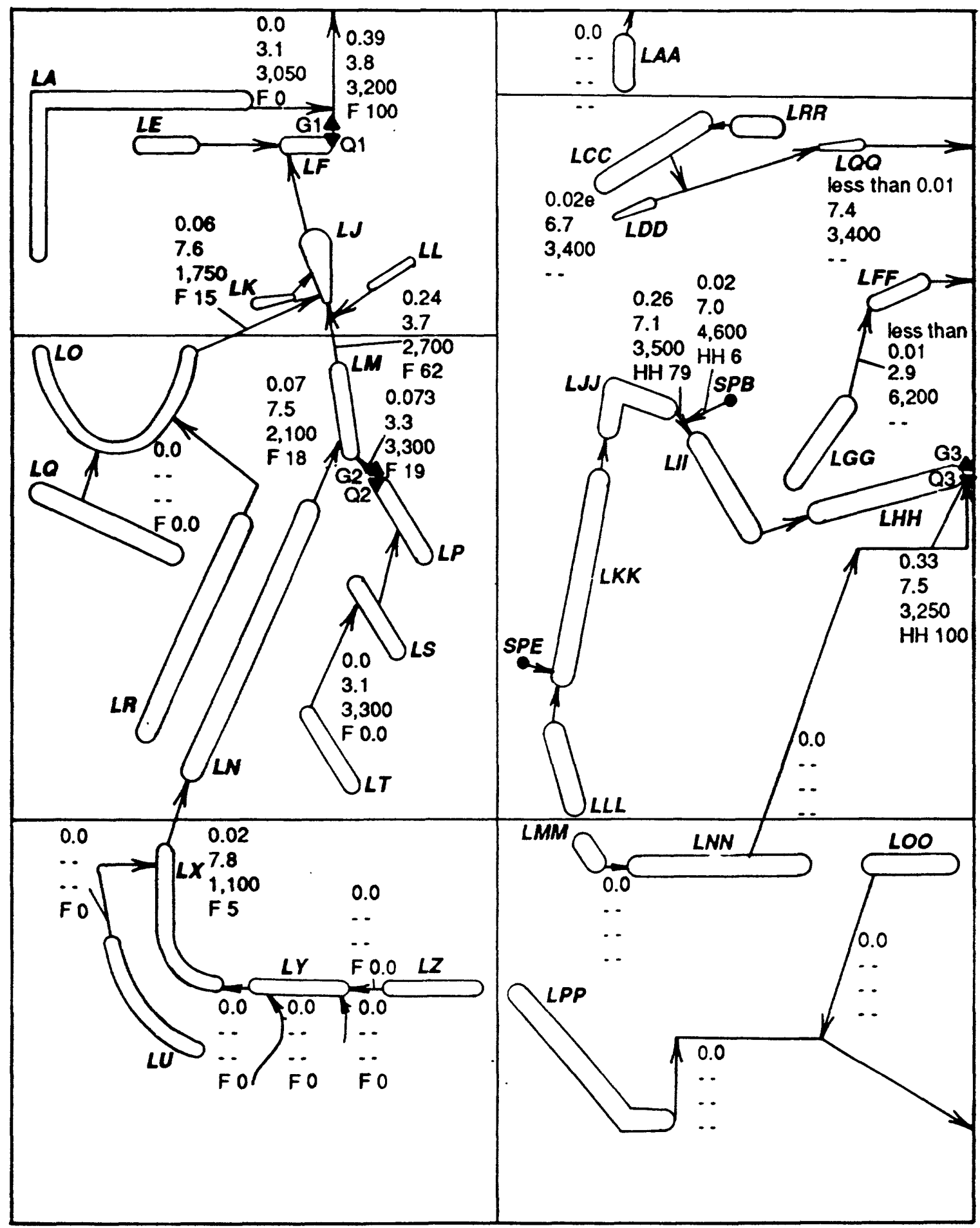

EXPLANATION

$\longrightarrow_{\text {LF LAKE AND IDENTIFIER }}$

0.06 LOCATION OF DISCHARGE, PH, AND SPECIFIC CONDUCTANCE MEASUREMENT.-TOP

7.6 number is discharge, in cubic feet per second; middle number is pH value; bottom number

1.750 is specific conductance, in microsiemens per centimeter at 25 degrees Celsius; $\theta$ indicates

F 15

SPE an estimated value; - - indicates no data; numbers following $\mathrm{F}$ and $\mathrm{HH}$ indicate outflow as percentage of outilow from lakes LF or LHH

a SPRING AND IDENTIFIER

$\rightarrow$ STREAM SEGMENT

Q1 STREAMFLOW-GAGING STATION AND NUMBER

Q1 WATER-QUALTTY MONITOR AND NUMBER

Figure 8.--Discharge, pH, and specific conductance measurements made Seplember 10-13, 1985. 


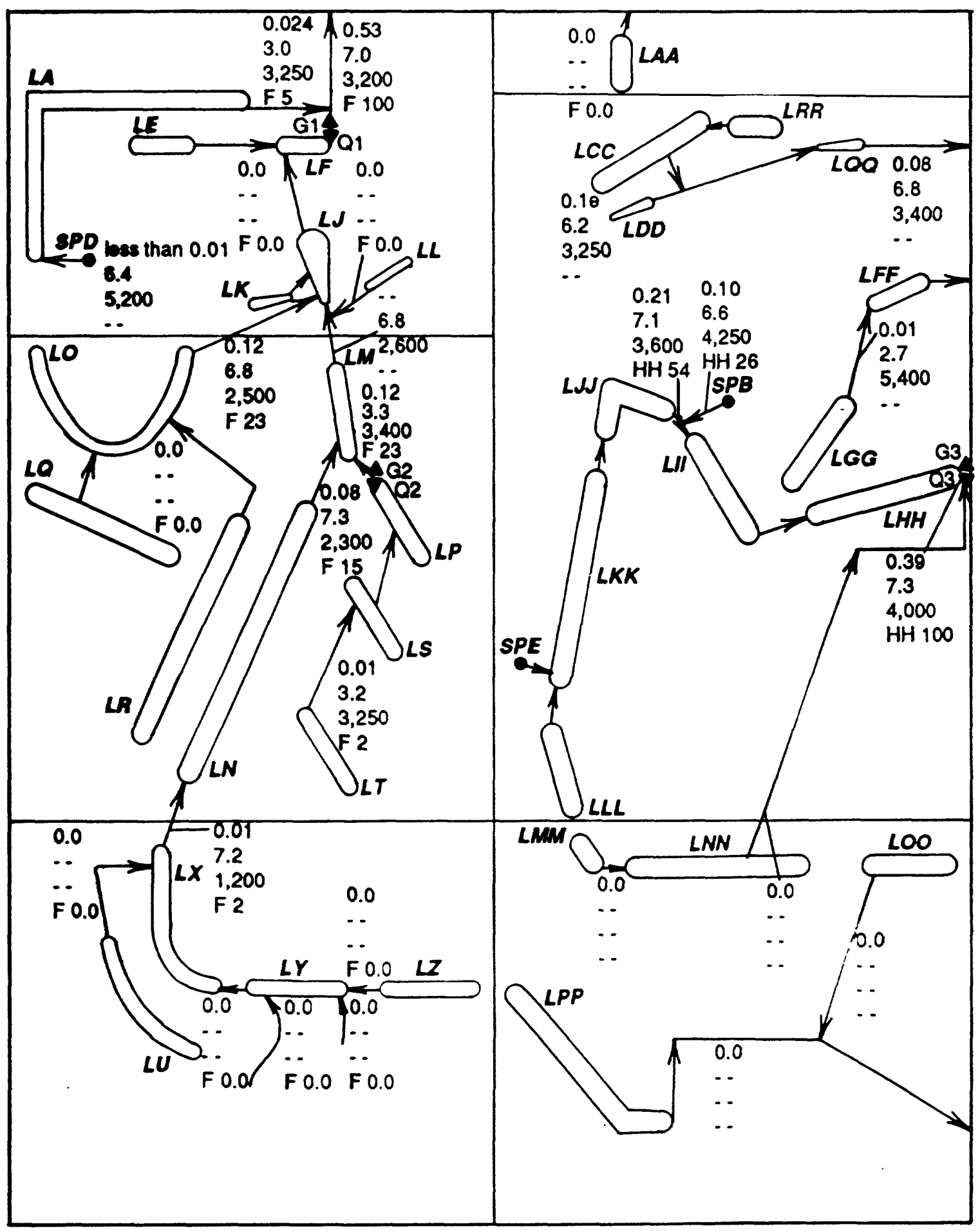

EXPLANATION

LF LAKE AND IDENTIFIER

0.10 LOCATION OF DISCHARGE, PH, AND SPECIFIC CONDUCTANCE MEASUREMENT--TOP 6.6 number is discharge, in cubic feet per second; middle number is pH value; bottom number 4,250 is specific conductance, in microsiemens per centimeter at 25 degrees Celsius; e indicates F15 an estimated value; - - indicates no data; numbers following $\mathrm{F}$ and $\mathrm{HH}$ indicate outtlow as percentage of outtiow from lakes LF or LHH

SPEA SPRING AND IDENTIFIER

$\longrightarrow$ STREAM SEGMENT

QQ1 STREAMFLOW-GAGING STATION AND NUMBER

VQ1 WATER-QUALITY MONITOR AND NUMBER

Figure 9.--Discharge, pH, and specific conductance measurements made April 21-25, 1986. 


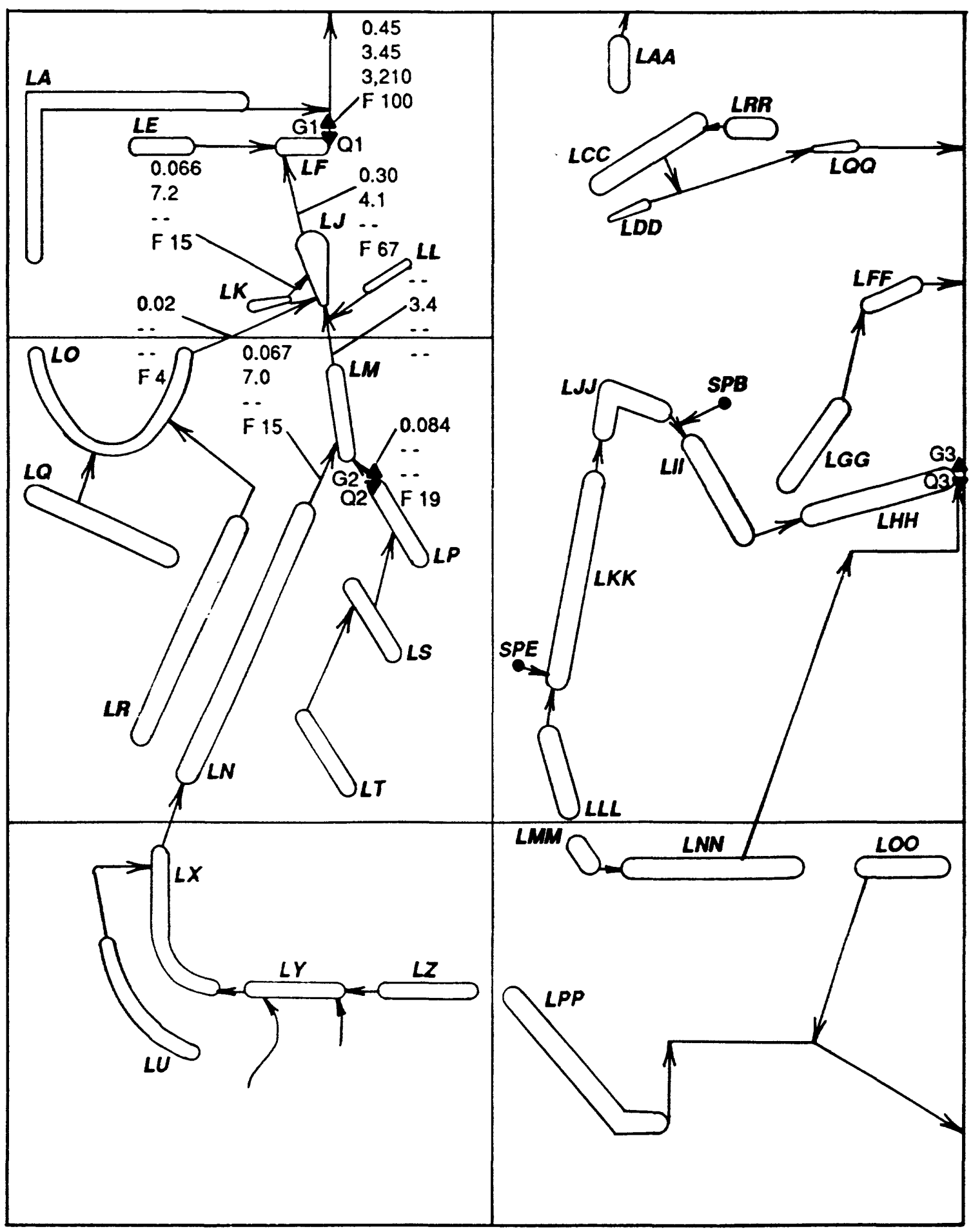

EXPLANATION

LF LAKE AND WENTIFIER

0.45 LOCATION OF DISCHARGE, pH, AND SPECIFIC CONDUCTANCE MEASUREMENT--TOP

3.45 number is discharge, in cubic feet per second; middle number is pH value; bottom number

3,210 is specific conductance, in microsiemens per contimeter at 25 degrees Celsius; $\theta$ indicates

$F 100$

SPE an estimated value; - - indicates no data; numbers following $F$ indicale outflow as percentage of outflow from lake LF

Q. SPRING AND IDENTIFIER

$\longrightarrow$ STREAM SEGMENT

G1 STREAMFLOW-GAGING STATION AND NUMBER

VQ1 WATER-QUALITY MONITOR AND NUMBER

Figure 10.--Discharge, pH, and specific conductance measurements made July 9, 1986. 


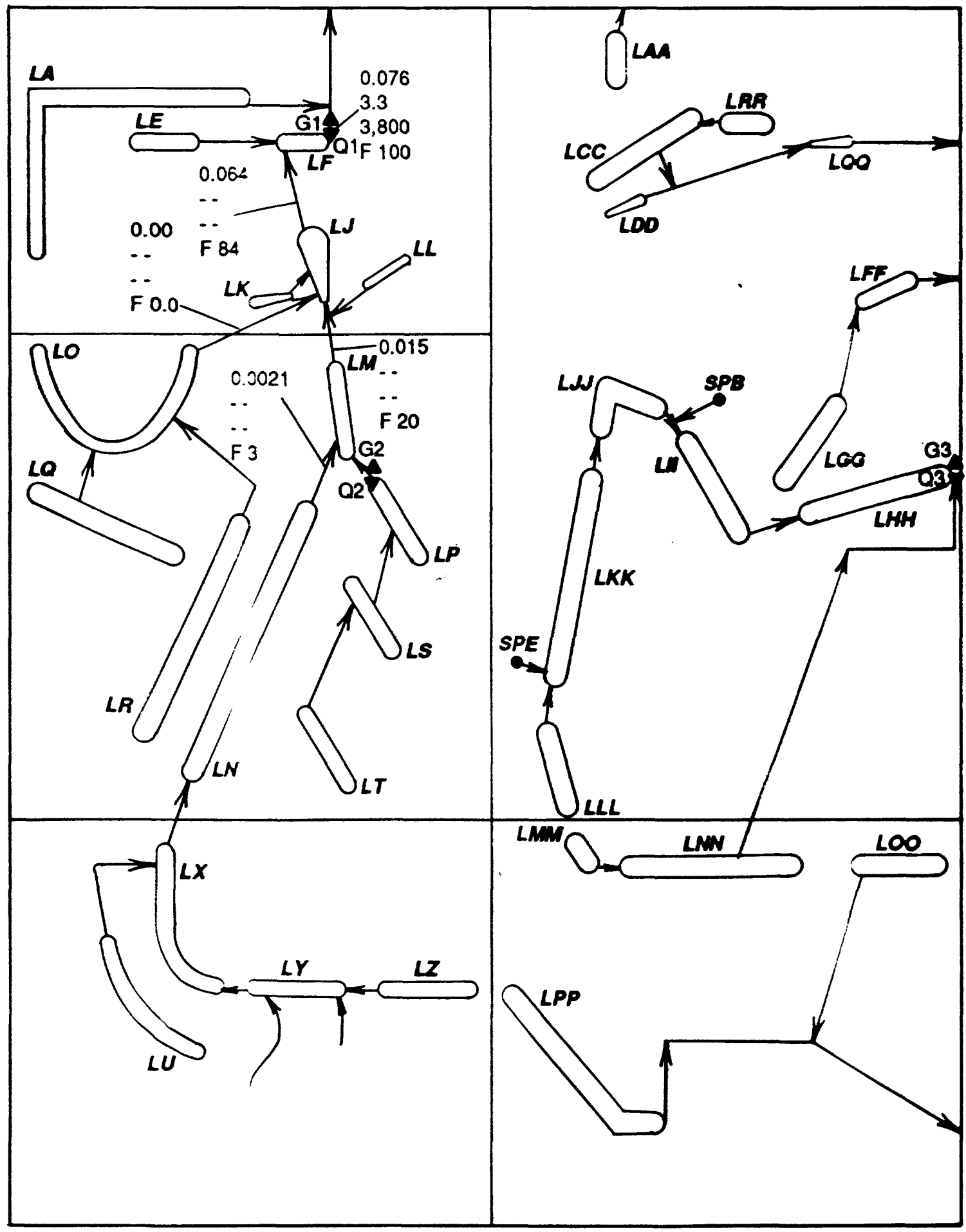

EXPLANATION

F LAKE AND IDENTIFIER

0.076 LOCATION OF DISCHARGE, PH, AND SPECIFIC CONDUCTANCE MEASUREMENT--TOP

3.3

3,800 number is discharge, in cubic feet per second; middle number is pH value; bottom number

F 84

SPE is specific conductance, in microsiemens per contimeter at 25 degrees Colsius; * indicates an estimated value; - - indicates no data; numbers following $F$ indicato outflow as percentage of outtlow from lake LF

Q SPRING AND IDENTIFIER

$\longrightarrow$ STREAM SEGMENT

$\triangle$ G1 STREAMFLOW-GAGING STATION AND NUMBER

DQ1 WATER-QUALITY MONITOR AND NUMBER

Figure 11.--Discharge, pH, and specific conductance measurements made July 31, 1986. 


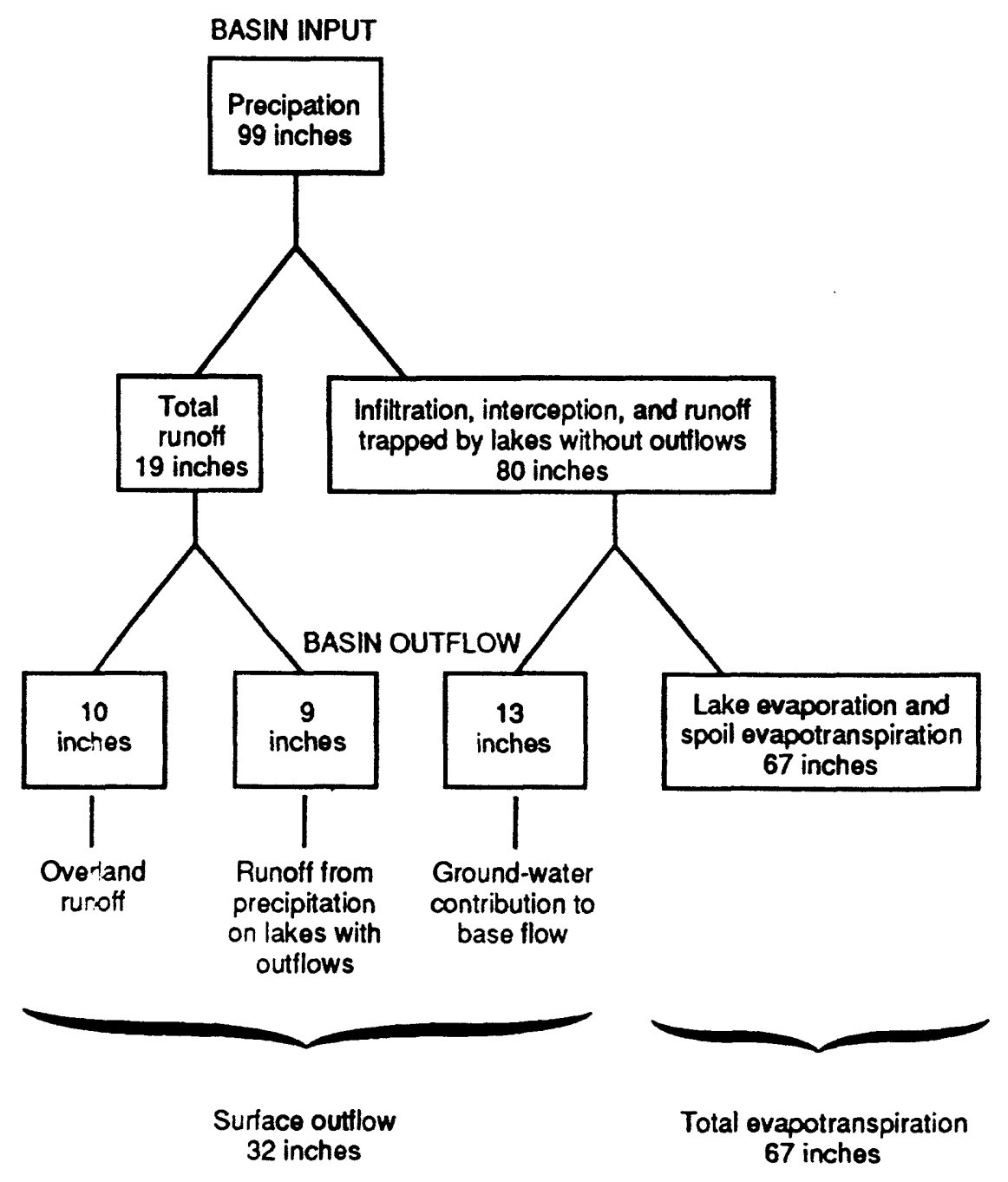

Figure 12.--Two-year water budget for the Horn Branch basin. 
spoil water was negligible compared to the total quantity of discharge, 68 percent of precipitation was lost to evapotranspiration from lakes, streams, and spoil (table 2). This percentage is 6 to 15 percent more than the percentages in the larger unmined basins of the South Grand and Little Osage Rivers (table 2), even though the Horn Branch basin has sparse vegetation. This small quantity of increased evapotranspiration may have been caused by the large number of lakes in the Horn Branch basin.

The hydrograph from site G1 was separated into contributions from overland runoff and from ground water using a technique described by Linsley and others (1975). Streamflow recession curves from site G1, plotted on semilogarithmic paper, indicated that the slope of the recessions beginning the day after rainfall ended became flatter with time and had two characteristic slopes (fig. 13). The initial steeper recession slope averaged 17 days per log cycle of discharge, and the subsequent slope averaged 46 days per log cycle until the next rise. In a small mined basin such as Horn Branch basin, virtually all overland runoff reached a stream or lake within a few hours after rainfall ended, but the lakes stored runoff and released it much slower than from an unmined basin. The release of this stored water accounted for the initial steep slope of the recession curve. The subsequent flatter slope of the recession curve was assumed to be ground-water discharge alone. Ground-water discharge then was separated from overland runoff by extending the ground-water slope back under the steeper slopes of the hydrograph. All discharge above the ground-water hydrograph was considered overland runoff. These two hydrographs were integrated over a 2-year period, and $19 \mathrm{in.} \mathrm{of} \mathrm{overland} \mathrm{runoff} \mathrm{and} 13 \mathrm{in.} \mathrm{of} \mathrm{ground-water}$ discharge were calculated for the basin. Therefore, about 40 percent of the outflow from Horn Branch was ground water that had passed through the spoil. Using an aquifer volume of 36,000 acre-feet (computed from figs. 5 and 6), an estimated effective porosity of 25 percent, and ground-water discharge of $6.5 \mathrm{in}$. per year, the average residence time of ground water in the spoil was about 14 years. Of the $19 \mathrm{in}$. of runoff, $9 \mathrm{in}$. was precipitation falling directly on 110 acres of lakes that have surface outflows most of the time. The remaining $10 \mathrm{in}$. were from overland runoff that represented only 11 percent of the precipitation on 1,090 acres of nonlake surface in the Horn Branch basin.

A primary reason for small volumes of overland runoff was the large areas of internal drainage that route runoff into shallow (less than $8 \mathrm{ft}$ deep) recharge lakes. These lakes supplied much larger quantities of recharge to ground water than did the noninundated spoil surfaces. Water levels of 10 shallow recharge lakes were recorded from staff gages at intervals ranging from 1 to 15 days from May to November 1985 and March to September 1986. Continuous water-level data were collected from another shallow recharge lake (lake L17) during these same periods. The rate of daily water-level decline was computed for nonrunoff periods from 2 to 15 days in length. These rates of decline were averaged for each lake, then the 11 averages were averaged to determine a mean daily rate of decline for the study area (table 4). The mean decline was $0.066 \mathrm{ft} / \mathrm{d}$ (feet per day, table 4), which is more than four times the May through October average for lake evaporation $(0.014 \mathrm{ft} / \mathrm{d})$ in the region (U.S. Weather Bureau, 1959). Pan evaporation at both Weather Bureau measuring sites within $75 \mathrm{mi}$ of the study area (Lakeside and Mount Vernon, Missouri, fig. 1) was within 5 percent of the long-term average during 1985 and 1986 (National Oceanic and Atmospheric Administration, 1984-86a), indicating lake evaporation was at near normal rates during data collection. The exact quantity of lake-bottom recharge to ground water is unknown. However, if even only 75 percent of the difference between average daily lake decline and average daily lake evaporation recharged ground water and 40 acres of the area were covered by recharge lakes, then more than 85 percent of the estimated $13 \mathrm{in}$. of ground-water recharge is accounted for. Therefore, as these lakes disappear because of erosion, the ground-water recharge, ground-water levels, and base flows will decrease.

\section{WATER CHEMISTRY}

The chemical reactions that produce acidic mine drainage have been described by many authors. Therefore, the details of this process are not reiterated in this report. However, a short summary of the process emphasizing selected reactions is presented to explain certain aspects of mine-water chemistry described later in this report.

The formation of sulfuric acid $\left(\mathrm{H}_{2} \mathrm{SO}_{4}\right)$ in mine waters is caused by the oxidation of iron disulfide minerals, primarily pyrite and marcasite $\left(\mathrm{FeS}_{2}\right)$, by either oxygen $\left(\mathrm{O}_{2}\right)$ or ferric iron $\left(\mathrm{Fe}^{+3}\right)$. According to Sato $(1960)$ and Nordstrom (1982), the initial oxidation of pyrite is described by the following reaction:

$$
\mathrm{FeS}_{2} \rightarrow \mathrm{Fe}^{+2}+\mathrm{S}_{2}{ }^{0}+2 \mathrm{e}^{*}
$$


Table 4.--Average daily declines of water levels in recharge lakes during nonrunoff periods 2 to 15 days between May and November 1985 and between March and September 1986

$[-$, not relevant $]$

\begin{tabular}{lcc}
\hline Lake & $\begin{array}{c}\text { Number of } \\
\text { nonrunoff periods }\end{array}$ & $\begin{array}{c}\text { Average } \\
\text { daily decline } \\
\text { (feet) }\end{array}$ \\
\hline L9 & 9 & 0.061 \\
L10 & 6 & .065 \\
L11 & 15 & .065 \\
L12 & 9 & .068 \\
L13 & 19 & .080 \\
L14 & 11 & .061 \\
L15 & 17 & .055 \\
L17 & 38 & .040 \\
L18 & 11 & .089 \\
L19 & 18 & .065 \\
L20 & 8 & .072 \\
Mean & & .066 \\
Standard deviation & 15 & .013 \\
\hline
\end{tabular}

The electron acceptor for this half-cell reaction can be either $\mathrm{O}_{2}$ or $\mathrm{Fe}^{+3}$. Aqueous elemental sulfur $\left(\mathrm{S}_{2}{ }^{0}\right)$ is unstable and quickly oxidizes according to:

$$
\mathrm{S}_{2}{ }^{0}+12 \mathrm{Fe}^{+3}+8 \mathrm{H}_{2} \mathrm{O} \rightarrow 2 \mathrm{SO}_{4}^{-2}+12 \mathrm{Fe}^{+2}+16 \mathrm{H}^{+1}
$$

or

$$
\mathrm{S}_{2}{ }^{0}+3 \mathrm{O}_{2}+2 \mathrm{H}_{2} \mathrm{O}->2 \mathrm{SO}^{-2}+4 \mathrm{H}^{+1} \text {. }
$$

Six electrons are transferred per sulfur atom in both reaction 2 and reaction 3 , indicating that these reactions are summations of several intermediate steps. Reaction 2 is dominate at $\mathrm{pH}$ values less than about 4.5 where large quantities of dissolved $\mathrm{Fe}^{+3}$ can be available for an oxidant. At larger $\mathrm{pH}$ values, $\mathrm{O}_{2}$ is the primary electron acceptor (reaction 3), but this reaction is much slower than reaction 2. Blevins and Chafin (1988) have shown with oxygen isotopes that reaction 2 produces most of the dissolved sulfate $\left(\mathrm{SO}_{4}{ }^{-2}\right)$ draining from the spoil. Therefore, it appears that $\mathrm{Fe}^{+3}$ is the primary oxidant. However, large quantities of $\mathrm{Fe}^{+3}$ are required for reactions 1 and 2 and are produced according to:

$$
\mathrm{Fe}^{+2} \rightarrow \mathrm{Fe}^{+3}+e^{-}
$$

The electron acceptor for this half-cell reaction, and thus, the driving oxidant for the whole chemical breakdown of pyrite, is $\mathrm{O}_{2}$, perhaps through the intermediate hydrogen peroxide $\left(\mathrm{H}_{2} \mathrm{O}_{2}\right)$. Reaction 4 proceeds slowly unless catalyzed by aerobic, thiobacillus bacteria. Singer and Stumm (1970) concluded that reaction 4 is the rate-limiting step in the production of acidic mine drainage.

Hydrolysis occurring during the precipitation of $\mathrm{Fe}^{+3}$ minerals also acidifies water in coal mines. This process can acidify streams and lakes where the availability of pyrite to water is limited. At $\mathrm{pH}$ values greater than about $4.0, \mathrm{Fe}^{+3}$ precipitates as amorphous ferrihydrite $\left[\mathrm{Fe}(\mathrm{OH})_{3}\right]$ :

$$
\mathrm{Fe}^{+3}+3 \mathrm{H}_{2} \mathrm{O} \rightarrow \mathrm{Fe}(\mathrm{OH})_{3}+3 \mathrm{H}^{+1} \text {. }
$$

At $\mathrm{pH}$ values greater than 4.5 , this reaction limits dissolved $\mathrm{Fe}^{+3}$ to small concentrations. The precipitation of jarosite $\left[\mathrm{XFe}_{3}\left(\mathrm{SO}_{4}\right)_{2}(\mathrm{OH})_{6}\right]$ can lower the $\mathrm{pH}$ to about 2.0 according to:

$$
\mathrm{X}^{+1}+3 \mathrm{Fe}^{+3}+2 \mathrm{SO}_{4}^{-2}+6 \mathrm{H}_{2} \mathrm{O} \rightarrow \mathrm{XFe}_{3}\left(\mathrm{SO}_{4}\right)_{2}(\mathrm{OH})_{6}+6 \mathrm{H}^{+1},
$$

where $\mathrm{X}$ is a singly charged cation, usually potassium $\left(\mathrm{K}^{+1}\right)$, sodium $\left(\mathrm{Na}^{+1}\right)$, or hydrogen $\left(\mathrm{H}^{+1}\right)$. 
Siderite $\left(\mathrm{FeCO}_{3}\right)$ is a common mineralogic form of iron in unmined rock. The oxidation of siderite and hydrolysis of the resultant $\mathrm{Fe}^{+3}$ at $\mathrm{pH}$ values greater than 4.5 produces $\mathrm{H}^{+1}$ according to:

$$
\mathrm{FeCO}_{3}+3 \mathrm{H}_{2} \mathrm{O} \rightarrow \mathrm{Fe}(\mathrm{OH})_{3}+\mathrm{HCO}_{3}^{-1}+2 \mathrm{H}^{+1}+e^{-} .
$$

In acidic water, one more of the $\mathrm{H}^{+1}$ may be removed by the bicarbonate ion $\left(\mathrm{HCO}_{3}{ }^{-1}\right)$ to form carbonic acid $\left(\mathrm{H}_{2} \mathrm{CO}_{3}\right)$.

\section{Chemistry of Surface Runoff}

Analyses of 10 samples of surface runoff collected during a 2.86-in. rain on May 13, 1985, are listed in table 5. The $\mathrm{pH}$ of runoff was between 3.2 and 3.5 over the areas of barren, unreclaimed spoil and is consistent with laboratory data that indicated almost immediate acidification of neutral water after addition of only small quantities of spoil collected from the land surface (fig. 14). Less than $25 \mathrm{ml}$ (milliliter) of surface spoil acidified more than $200 \mathrm{ml}$ of near neutral lake water [alkalinity as calcium carbonate $\left(\mathrm{CaCO}_{3}\right)$, about $100 \mathrm{mg} / \mathrm{L}$ (milligrams per liter)] to a $\mathrm{pH}$ less than 4.0. The changes in $\mathrm{pH}$ occurred in a matter of seconds. The effect of surface spoil on rainwater would be even more pronounced because of the low alkalinity and slightly lower $\mathrm{pH}$ of rainwater. The rapid acidification of rainwater probably was because of dissolution of ferric sulfates such as coquimbite $\left(\mathrm{Fe}_{2}\left(\mathrm{SO}_{4}\right)_{3} \cdot 9 \mathrm{H}_{2} \mathrm{O}\right.$; Nordstrom, 1982) and bisulfate $\left(\mathrm{HSO}_{4}{ }^{-1}\right)$ salts formed near the spoil surface between rains as depicted in reactions 8 and 9 ,

$$
\begin{aligned}
& \mathrm{Fe}_{2}\left(\mathrm{SO}_{4}\right)_{3} \cdot 9 \mathrm{H}_{2} \mathrm{O}-->2 \mathrm{Fe}(\mathrm{OH})_{3}+6 \mathrm{H}^{+1}+3 \mathrm{SO}_{4}^{-2}+3 \mathrm{H}_{2} \mathrm{O} . \\
& \mathrm{XHSO}_{4}->\mathrm{X}^{+1}+\mathrm{H}^{+1}+\mathrm{SO}_{4}^{-2} .
\end{aligned}
$$

Ferric sulfates and $\mathrm{HSO}_{4}^{-1}$ salts form from iron disulfide-oxidation products only as near-surface spoil water evaporates between storms and cause $\mathrm{H}^{+1}, \mathrm{SO}_{4}^{-2}$, and $\mathrm{Fe}^{+3}$ to reach large concentrations. The large concentrations also cause the rapid oxidation of pyrite according to reactions 1, 2, and 4. Also, Miller (1979) has suggested that when jarosite and ferrihydrite are present, acidic spoil water is buffered at $\mathrm{pH}$ values between 3.0 and 3.4, which is about the same range in $\mathrm{pH}$ detected in surface runoff from unvegetated spoil.

Samples collected near lakes LDD and LQQ (table 5) were collected from ungraded, but revegetated spoil in the eastern part of the study area. The $\mathrm{pH}$ values at these sites were about 2 to 3 units larger than those in the unvegetated areas, which would indicate that successful revegetation of spoil substantially decreases the acidity of runoff. The specific conductance of runoff from revegetated spoil also was less than the unreclaimed areas, indicating less dissolution in general in the vegetated areas. Decreased exposure of unoxidized pyrite by slowing erosion and the presence of organic material in revegetated spoil are likely causes of increased $\mathrm{pH}$ values of runoff. However, the $\mathrm{pH}$ values of runoff from the revegetated and reclaimed areas were 1 to 2 units less than runoff from the unmined area at site $\mathrm{S} 2$.

Samples collected immediately after the May 13, 1985, storm from small perched lakes with no surface outflow (table 6) had $\mathrm{pH}$ values similar to those of direct runoff from bare spoil. Although activities (chemically effective concentrations) of calcium $\left(\mathrm{Ca}^{+2}\right)$ and $\mathrm{SO}_{4}{ }^{-2}$, as calculated by WATEQ4F, were well below saturation, they were large enough to indicate that substantial quantities of calcite, coquimbite, $\mathrm{HSO}_{4}{ }^{-1}$ salts, or gypsum dissolve in the first few minutes of contact with the spoil surface. Dissolved $\mathrm{SO}_{4}^{-2}$ begins to form $\mathrm{HSO}_{4}^{-1}$ in substantial quantities at $\mathrm{pH}$ values less than 3.5, and thus, may help keep the $\mathrm{pH}$ of runoff from being much less than 3.0.

The $\mathrm{pH}$ values of samples collected from surface outflows of larger lakes immediately after the May 13, 1985, rain (table 7) were not appreciably different from base-flow $\mathrm{pH}$ values (figs. 15-17). This was because of the relatively large volumes of water stored in the lakes.

Continuous discharge, specific conductance, and $\mathrm{pH}$ data were collected at sites Q1, Q2, and Q3 and continuous rainfall data were collected at site RG (fig. 1). Horn Branch at site Q1 drained a mixture of acidic and near-neutral lakes and a land surface of mostly unreclaimed and unvegetated spoil. Water draining from lake $L N$ was always neutral, but water draining from lake LP (site Q2) always was acidic. The $\mathrm{pH}$ value at site Q1 was determined in large part by which of these two tributaries contributed the majority of flow. If the $\mathrm{pH}$ at site Q1 was more than 5.0 just before rainfall, runoff temporarily tended to decrease the $\mathrm{pH}$ value (figs. 15-17). However, if the $\mathrm{pH}$ was less than 5.0 just before rainfall, runoff tended to increase the $\mathrm{pH}$ value. Increases of $\mathrm{pH}$ value were 


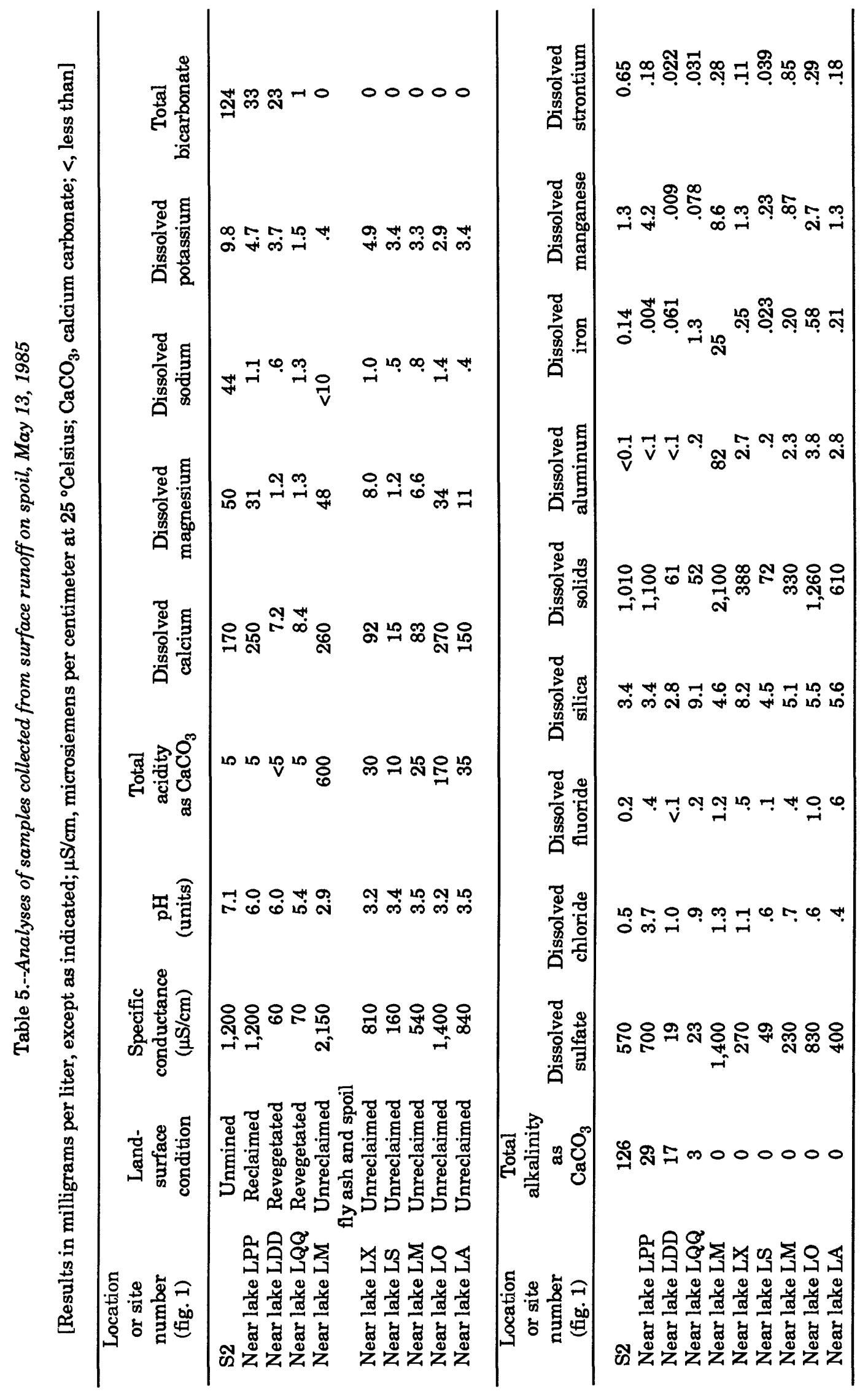




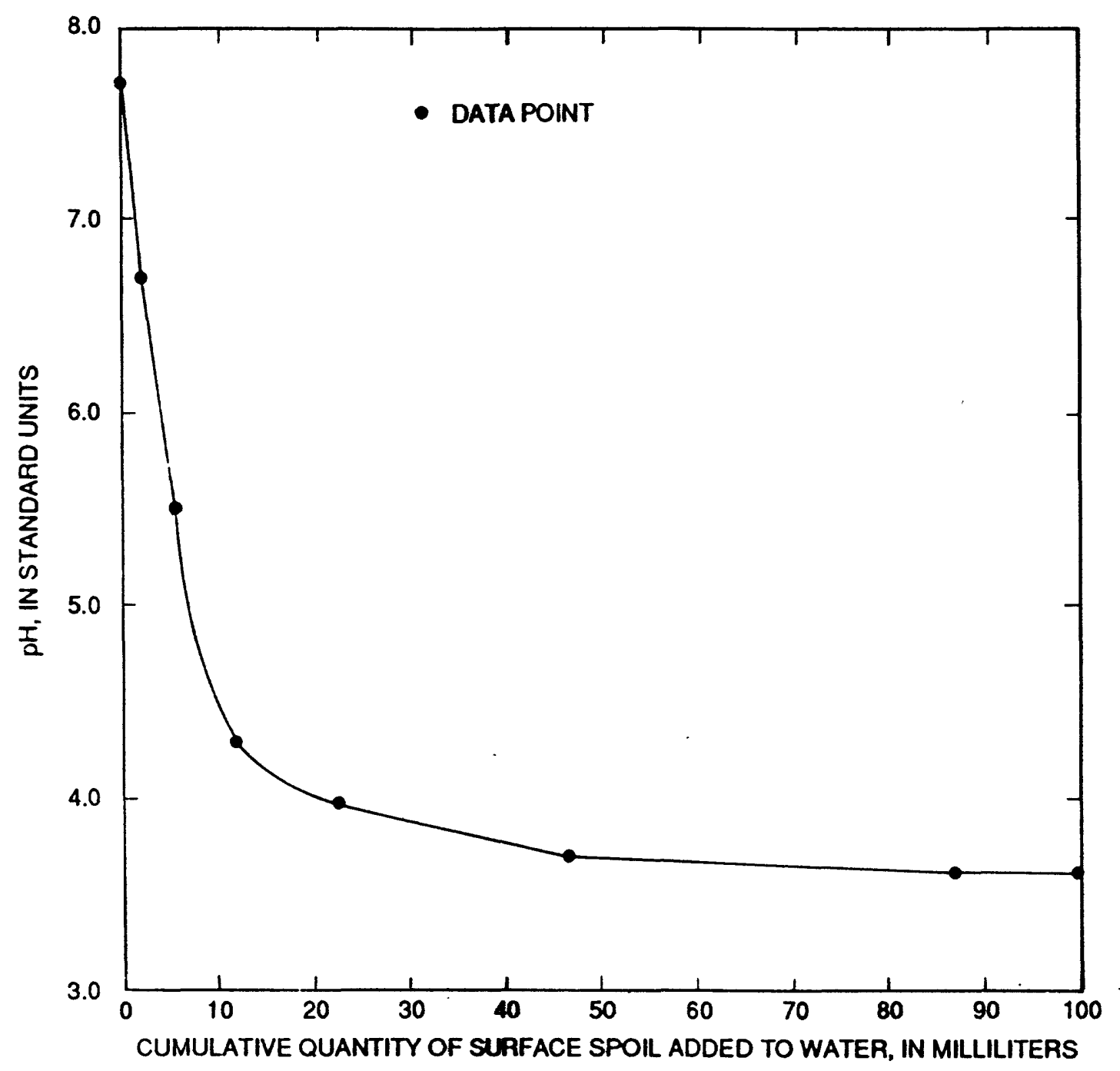

Figure 14.--Decrease in pH value of 213 milliliters of water from lake $L N$ with the addition of surface spoil. 


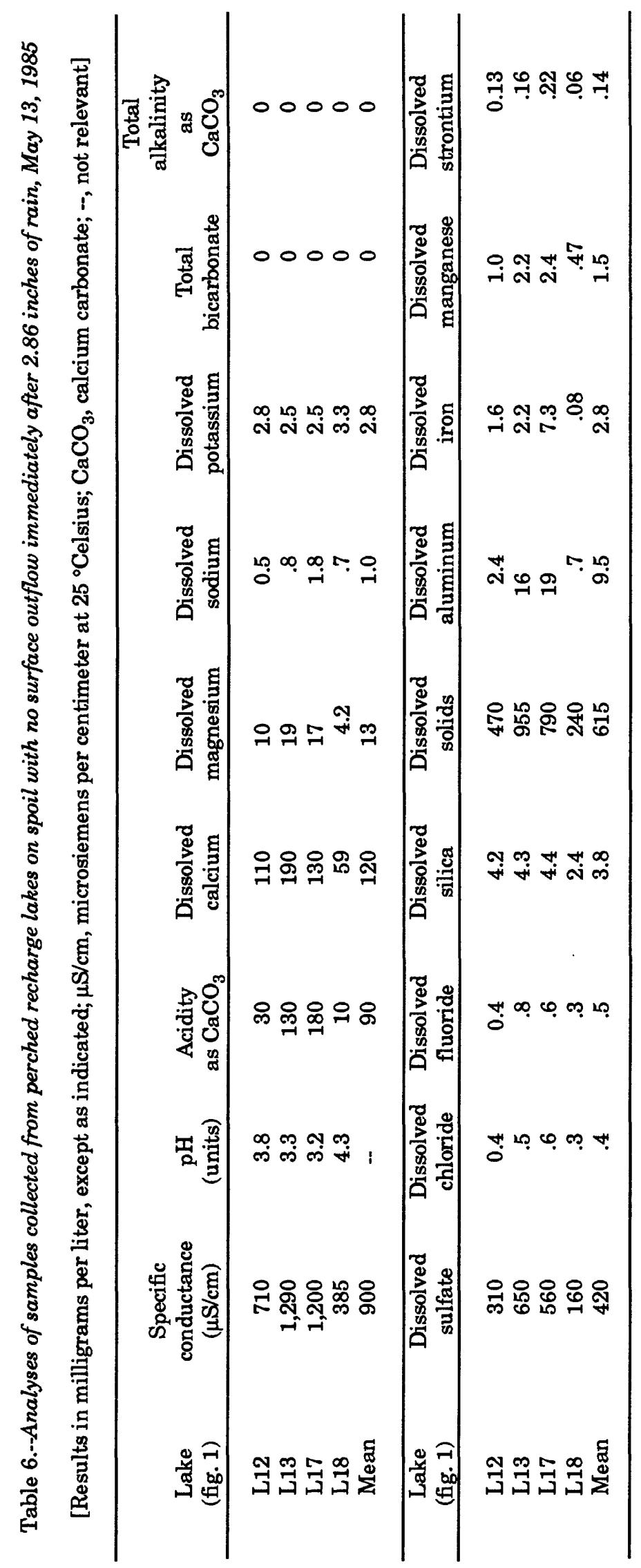




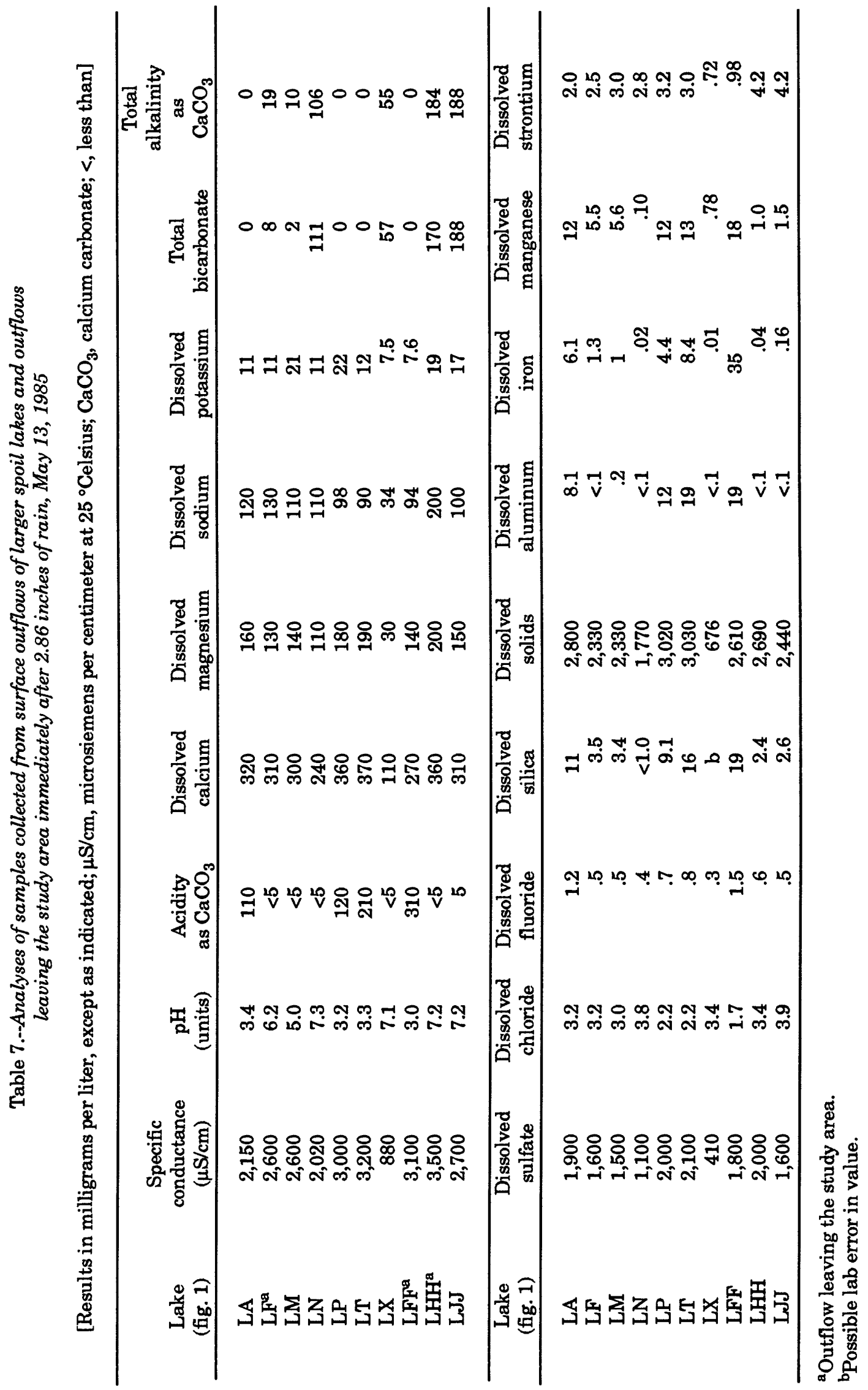




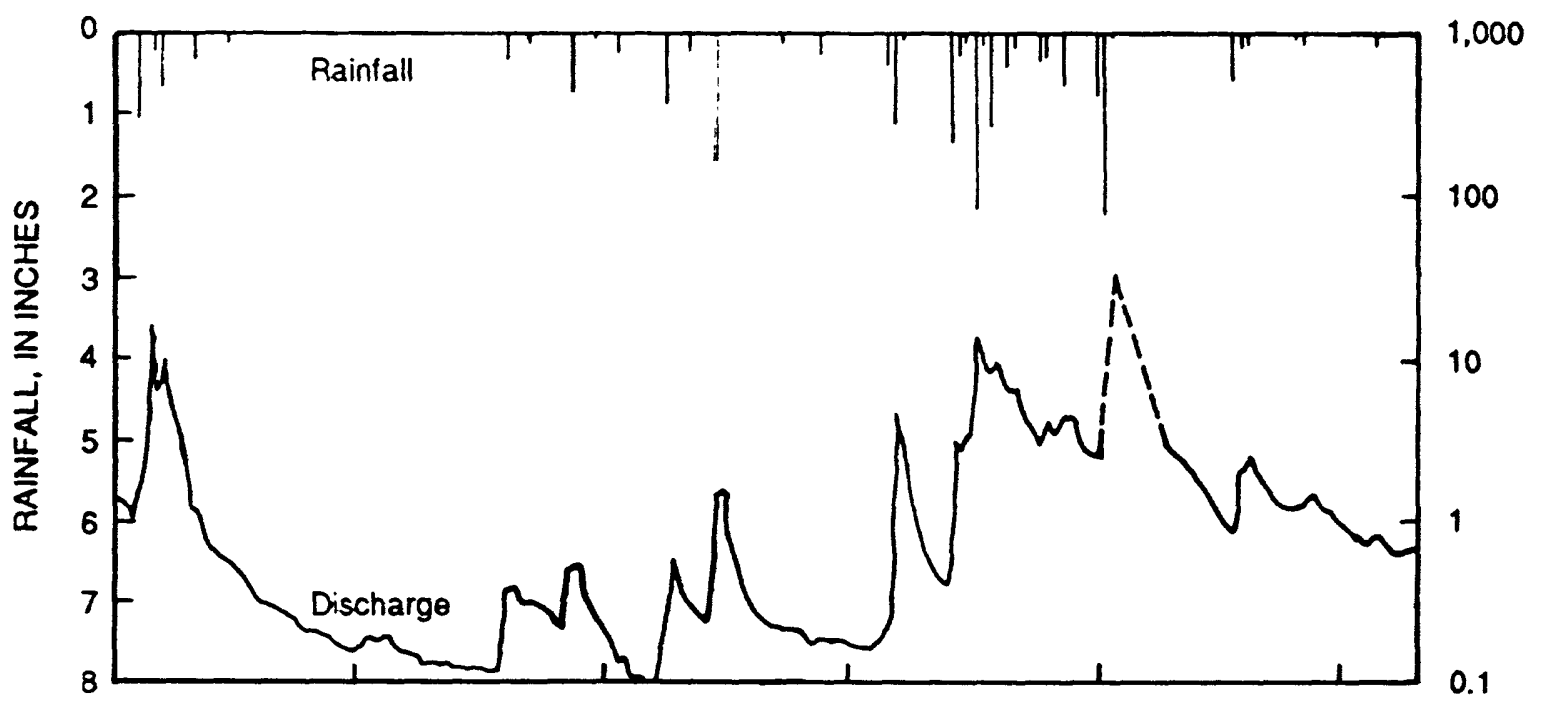

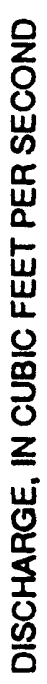
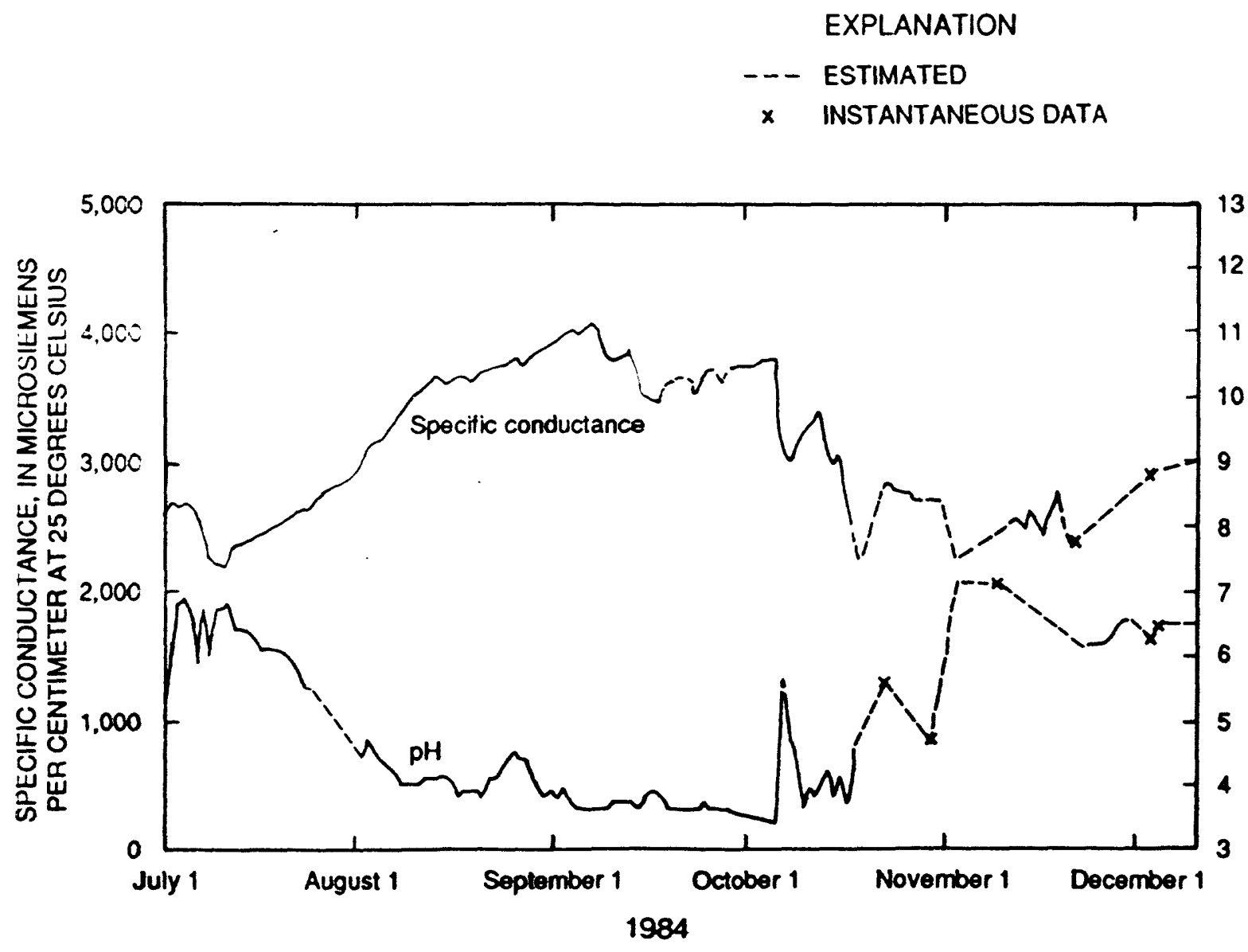

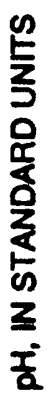

Figure 15.--Daily rainfall and daily mean discharge, specilic conduclance, and pH at site Q1, July 1 through December 15, 1984. 
ONOOJS

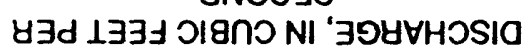
응 - 8 -
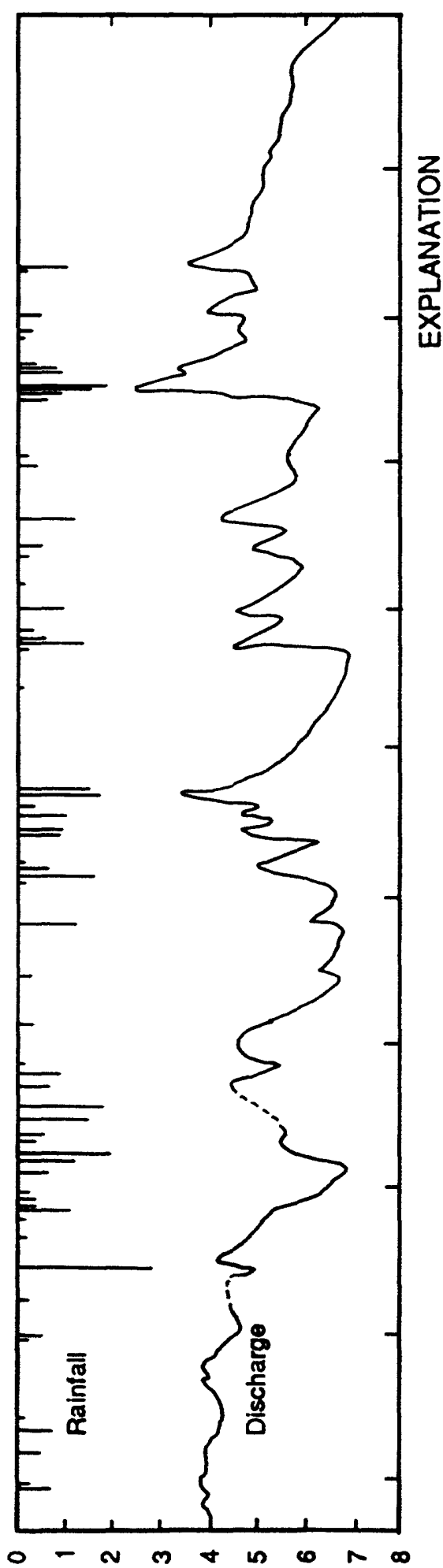

SЭHONI NI 'רדצNIVY
SIINT OUVONFIS NI 'HA

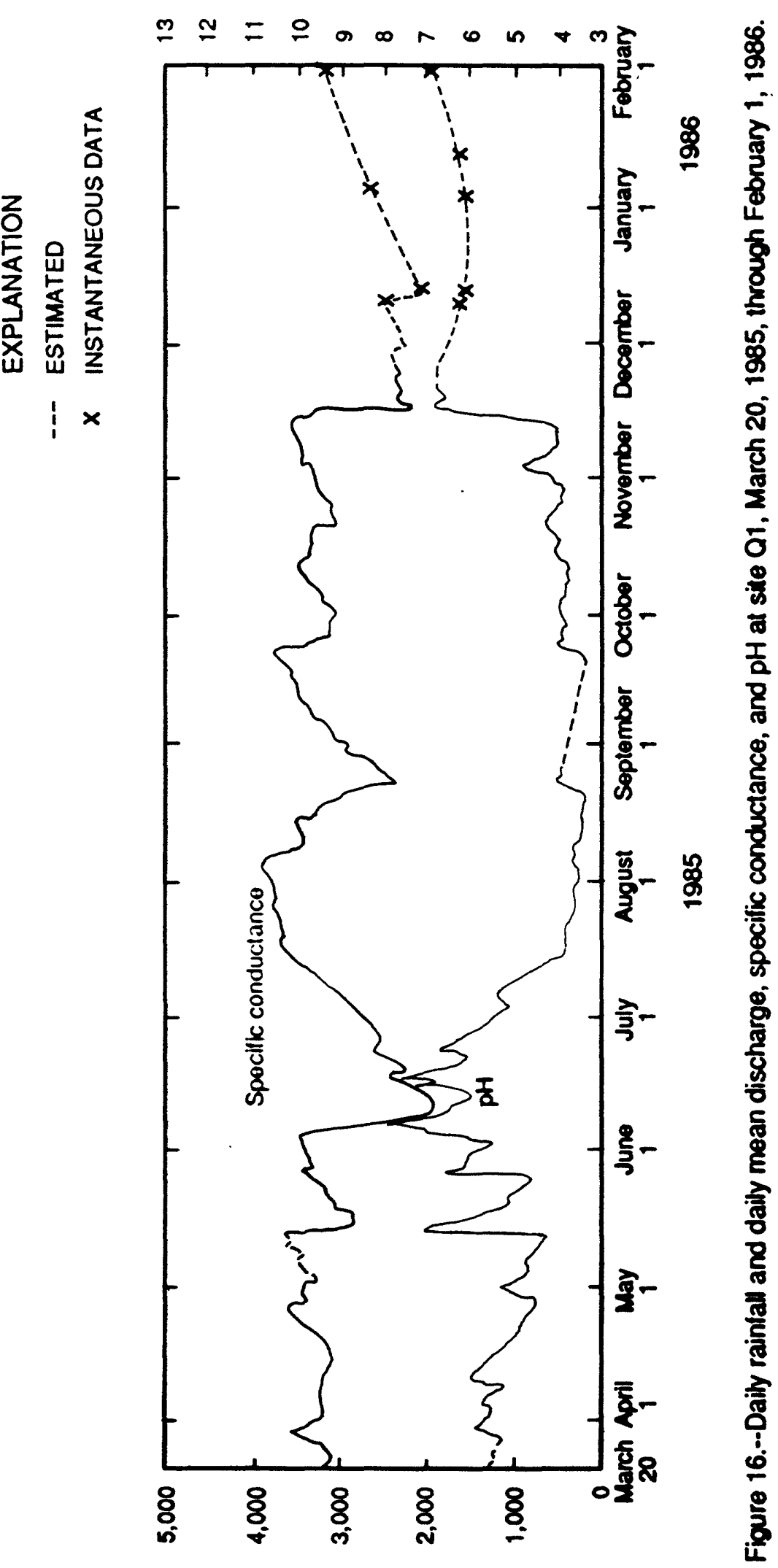

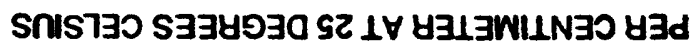

SNGWGISOYDIN NI ' $\exists O N \forall I O N O N O O$ OIHIOJdS 


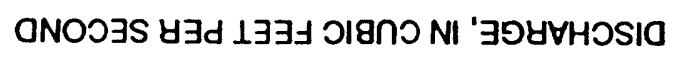

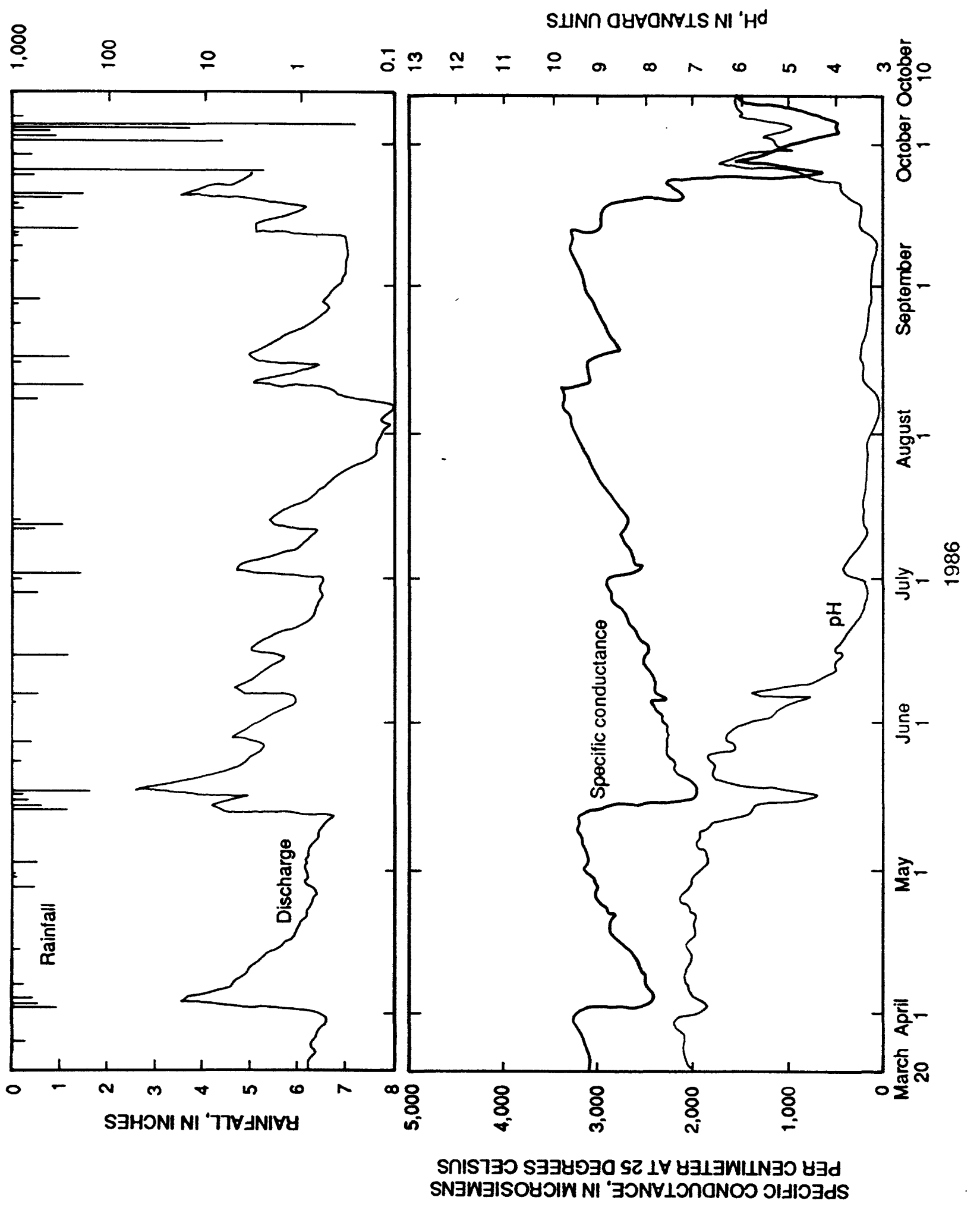

ஜ்

음

융

O

홍 
caused by flushing of neutral lake water and decreases were caused by acidic runoff. The $\mathrm{pH}$ values of runoff in Horn Branch were probably larger than they would have been if the areas of internal drainage had not held much of the acidic runoff.

At site $\mathrm{Q} 2$ between June 30 and December 3, 1985, daily values of $\mathrm{pH}$ ranged from 2.9 to 3.4 , with only the largest flows causing a slight increase in $\mathrm{pH}$. Specific conductance ranged from 2,300 (peak flow) to 3,700 (low flow) $\mu \mathrm{S} / \mathrm{cm}$ (microsiemens per centimeter at 25 degrees Celsius). The area drained by this site was unreclaimed and unvegetated. Much of the base flow was from two shallow lakes that effectively acidified all ground water entering them. Therefore, acidic runoff did not substantially change the already low $\mathrm{pH}$ value of water leaving the drainage area.

At site Q3 from June 29 to December 14, 1984, and March 20 to July 1, 1985, the pH ranged from 6.5 to 8.2, and the specific conductance ranged from 2,000 (peak flow) to 4,000 (low flow) $\mu \mathrm{S} / \mathrm{cm}$. This stream site received water from ungraded but mostly vegetated spoil in the eastern part of the study area with only small areas contributing overland runoff.

\section{Ground-Water Chemistry}

A summary of selected characteristics of the major dissolved constituents in water samples from wells completed in spoil is given in table 8 . Some information in this table was determined by speciating dissolved ions from 17 analyses of water from 11 wells and determining saturation indices for various minerals from WATEQ4F. Saturation indices [log (activity product/equilibrium constant)] for selected minerals were calculated by WATEQ4F (table 9) based on data from water analyses and temperatures measured onsite. Eh values were required to speciate iron and manganese ions that have more than one valence. Values of Eh in ground water were estimated using $\mathrm{pH}$ and dissolved-iron concentrations (Barnes and Clark, 1964). These values were generally near 0.25 volt and close to a value of 0.23 volt measured in well W30 1 year after this study on September 25, 1987. The dissolved oxygen concentration in this well was below the detection limit of $0.1 \mathrm{mg} / \mathrm{L}$ and no hydrogen sulfide $\left(\mathrm{H}_{2} \mathrm{~S}\right)$ odor was detected. To determine the sensitivity of model results to errors in estimates of the Eh value, the models were run at $\mathrm{Eh}$ values 0.1 volt greater than and less than the estimate. There was little change in dominant aqueous species or saturation indices of manganese minerals. However, saturation indices of $\mathrm{Fe}^{+3}$ minerals, such as ferrihydrite and jarosite, were sensitive to even 0.05 -volt changes in Eh.

Table 8.--Characteristics of major dissolved constituents in water samples from wells completed in spoil

\begin{tabular}{|c|c|c|c|}
\hline Constituent & $\begin{array}{c}\text { Probable } \\
\text { major sources }\end{array}$ & $\begin{array}{l}\text { Probable } \\
\text { controls }\end{array}$ & $\begin{array}{c}\text { Dominant } \\
\text { species }\end{array}$ \\
\hline $\mathrm{H}^{+1}$ & Oxidation of iron disulfides and $\mathrm{Fe}^{+2}$ & Dissolved-oxygen concentration & $\mathrm{H}^{+1}, \mathrm{HCO}_{3}^{-1}$ \\
\hline $\mathrm{Ca}^{+2}$ & Calcite and gypsum & Solubility of gypsum and calcite & $\mathrm{Ca}^{+2}, \mathrm{CaSO}_{4}{ }^{\circ}$ \\
\hline $\mathrm{Mg}^{+2}$ & $\begin{array}{l}\text { Limestone (substitution for } \mathrm{Ca}^{+2} \text { ), } \\
\text { dolomite, and clays }\end{array}$ & Limited by source rock & $\mathrm{Mg}^{+2}, \mathrm{MgSO}_{4}^{\circ}$ \\
\hline $\mathrm{Na}^{+1}$ & $\begin{array}{l}\text { Silicate minerals, impurities in } \\
\text { cementing agents, cation exchange } \\
\text { from clays }\end{array}$ & Limited by source rock & $\mathrm{Na}^{+1}$ \\
\hline $\mathrm{Fe}^{+2}$ & Pyrite and siderite & $\mathrm{pH}$, solubility of siderite & $\mathrm{FeSO}_{4}{ }^{\circ}, \mathrm{FeOH}^{-1}$ \\
\hline $\mathrm{Fe}^{+3}$ & Oxidation of ferrous iron & $\begin{array}{l}\text { Solubility of iron oxyhydroxides } \\
\text { and jarosite }\end{array}$ & $\mathrm{Fe}(\mathrm{OH})_{2}^{-1}$ \\
\hline $\mathrm{Mn}^{+2}$ & $\begin{array}{l}\text { Limestone (substitution for } \mathrm{Ca}^{+2} \text { ) } \\
\text { and clays }\end{array}$ & pH, solubility of rhodochrosite & $\mathrm{Mn}^{+2}$ \\
\hline $\mathrm{Al}^{+3}$ & Clay and silicate minerals & $\begin{array}{l}\text { pH, solubility of } \\
\text { aluminum hydroxides }\end{array}$ & $\begin{array}{l}\mathrm{AlF}_{2}^{+1} \\
\mathrm{Al}(\mathrm{OH})_{2}^{+1}\end{array}$ \\
\hline $\mathrm{SO}_{4}^{-2}$ & Pyrite, gypsum & Solubility of gypsum and jarosite & $\mathrm{SO}_{4}^{-2}, \mathrm{CaSO}_{4}{ }^{\circ}$ \\
\hline $\mathrm{CO}_{3}^{-2}$ & Calcite & $\mathrm{pH}$, solubility of calcite & $\mathrm{HCO}_{3}{ }^{-1}$ \\
\hline
\end{tabular}




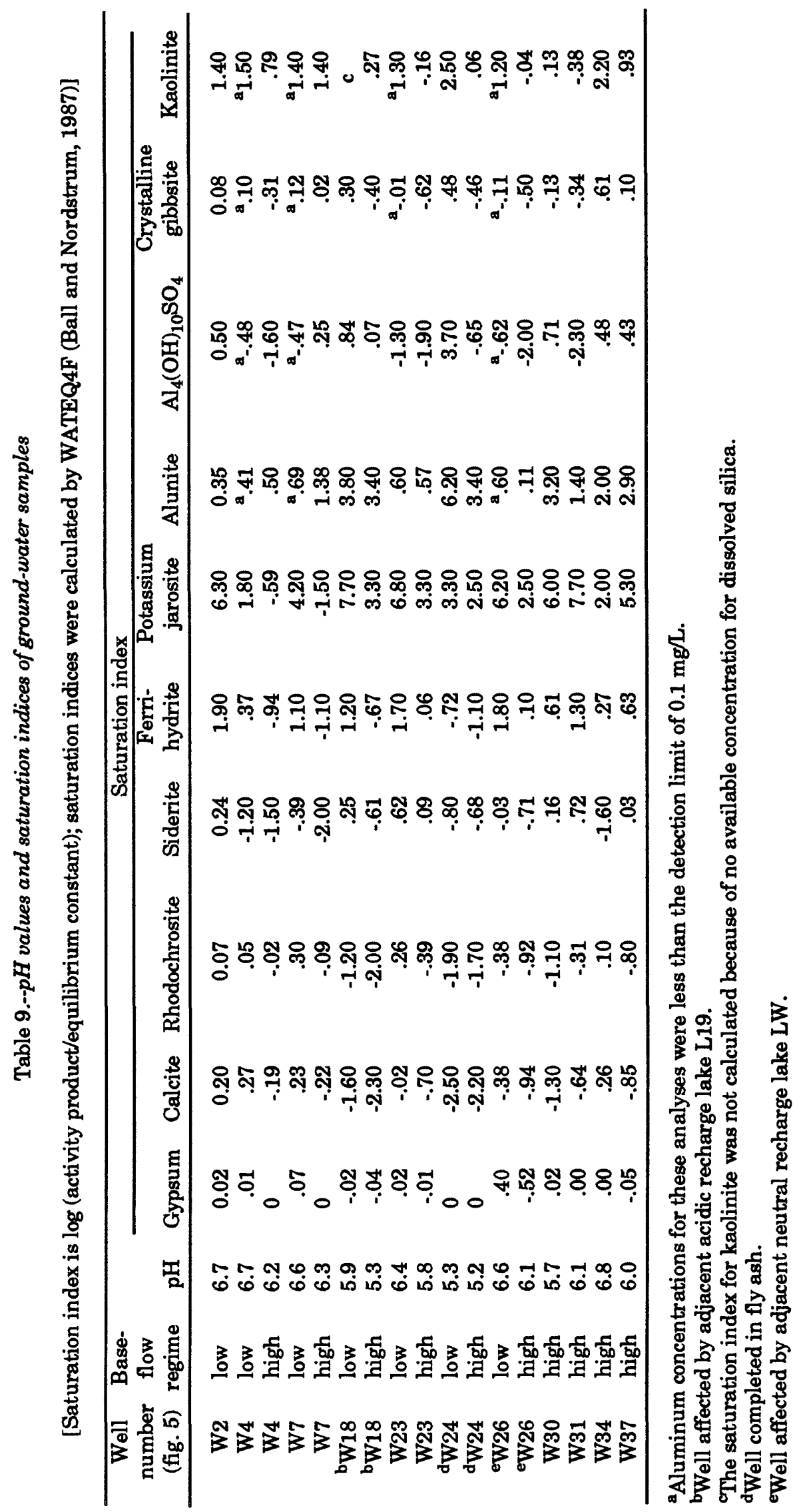


The pH of ground-water samples from all wells and springs except W18 and W24 ranged from 5.7 to 7.0 (tables 10 and 11). Well W18 was near lake L19, which was an acidic recharge lake in the southern part of the study area (fig. 1). Water in well $\mathrm{W} 18$ had $\mathrm{pH}$ values less than 4.0 after intense rains, but increased to values about 6.0 during dry weather. Water in well W24 (pH 5.2-5.3) probably was affected by fly ash from the power plant. Apparently, acid production in the ground-water system was limited by low dissolved-oxygen concentrations that slowed the rates of reactions $1,2,3$, and 4. Dissolved-oxygen concentrations measured in water in observation wells during low base flow were at or below the detection limit of $0.1 \mathrm{mg} / \mathrm{L}$. VomDemfange (1974) determined that pyritic sulfur was substantially depleted in only the top $2 \mathrm{ft}$ of spoil at two sites in and one site near the study area. He also concluded that pyrite oxidation was limited by oxygen depletion at depth. $\mathrm{HCO}_{3}{ }^{-1}$ concentrations of 265 to $800 \mathrm{mg} / \mathrm{L}$ in ground-water samples from wells not adjacent to acidic lakes or completed in fly ash indicate substantial quantities of carbonate minerals remained in the spoil and neutralized acidic recharge after a short time. Sources of $\mathrm{CO}_{3}^{-2}$ in the spoil are the Tiawah Limestone Member ${ }^{1}$ in the Scammon Formation, numerous thin layers of limestone above the Tiawah ${ }^{1}$, numerous vertical stringers of limestone that penetrate several of the shales, and siderite (fig. 2).

Calcite and gypsum are common constituents of rocks in the area (drillers' logs for water-supply wells in Montrose, Missouri, on file at Missouri Division of Geology and Land Survey, office in Rolla, Missouri), and consequently $\mathrm{Ca}^{+2}$ usually was measured in larger concentrations than any other cation in spoil water. At the low $\mathrm{pH}$ values detected near the spoil surface, calcite dissolves more rapidly than gypsum. Therefore, calcite is probably the major source of $\mathrm{Ca}^{+2}$ in ground water. Also, Blevins and Chafin (1988) used oxygen isotopes to show that most $\mathrm{SO}_{4}^{-2}$ dissolved in mine water was from pyrite oxidation and not from dissolution of premining gypsum. Ground water was saturated with calcite only in wells where $\mathrm{pH}$ values were greater than 6.4 (table 9), but gypsum was near saturation in all wells not near recharge lakes. In wells where calcite was undersaturated and gypsum was saturated, the dissolution of calcite could cause the precipitation of gypsum. At $\mathrm{pH}$ values greater than 6.4 and under the slow rate of pyrite oxidation at depth, calcite and gypsum approach saturated equilibrium with $\mathrm{Ca}^{+2}$ concentrations between 520 and $680 \mathrm{mg} / \mathrm{L}$ (table 10, wells $2,4,7$, and 34).

The second largest cation concentration in ground water was usually magnesium $\left(\mathrm{Mg}^{+2}\right.$; tables 10 and 11$)$. The mole ratio of $\mathrm{Ca}^{+2}$ to $\mathrm{Mg}^{+2}$ in ground-water samples averaged 1.6. This small ratio is evidence that $\mathrm{Ca}^{+2}$ was taken out of solution at a faster rate than $\mathbf{M g}^{+2}$. No plausible $\mathbf{M g}^{+2}$ mineral was near saturation in spoil water. However, both calcite and gypsum were commonly near or above saturation, and this fact probably limited concentrations of $\mathrm{Ca}^{+2}$. WATEQ4F speciation calculated 40 percent of dissolved $\mathrm{Ca}^{+2}$ and $\mathrm{Mg}^{+2}$ was in the form of aqueous sulfates. The propensity of $\mathrm{SO}_{4}{ }^{-2}$ to form complexes permits larger concentrations of dissolved $\mathrm{Ca}^{+2}$ and $\mathrm{Mg}^{+2}$.

$\mathrm{Na}^{+1}$ concentrations were nearly as large as $\mathrm{Mg}^{+2}$ concentrations in spoil water (tables 10 and 11). The concentrations probably originated from silicate minerals, impurities in cementing agents (Hem, 1985), and the abundant clay in spoil, where the large concentrations of $\mathrm{Ca}^{+2}$ may have forced $\mathrm{Na}^{+1}$ from cation-exchange sites. Also, 10 samples of ground water from undisturbed Pennsylvanian rocks in adjacent Bates County had $\mathrm{Na}^{+1}$ and chloride $\left(\mathrm{Cl}^{-1}\right)$ concentrations ranging between about 500 and $4,000 \mathrm{mg} / \mathrm{L}$ (Kleeschulte and others, 1985). The last traces of sodium chloride $(\mathrm{NaCl})$ may persist for long periods where circulation of water is impaired (Hem, 1985) and may account for the $\mathrm{Na}^{+1}$ detected in spoil water. However, the small concentrations of $\mathrm{Cl}^{-1}$ in ground water (averaging less than $5 \mathrm{mg} / \mathrm{L}$ ) indicated $\mathrm{NaCl}$ was not a large source of $\mathrm{Na}^{+1}$. However, Hem (1985) also suggested that the large diameter of the chloride ion causes it to be retained in molecular layers of clay and shale, which are the most abundant constituents of mine spoil. Concentrations of $\mathrm{Na}^{+1}$ and $\mathrm{Cl}^{-1}$ were limited by source material rather than the solubility product of a salt in spoil water.

The largest concentration of any ion in spoil water was $\mathrm{SO}_{4}^{-2}$ (tables 10 and 11). Blevins and Chafin (1988) stated the largest source for $\mathrm{SO}_{4}^{-2}$ was oxidation of iron disulfides. This oxidation primarily occurs near the spoil surface where $\mathrm{pH}$ values are small and oxygen is available. The tendency of $\mathrm{SO}_{4}^{-2}$ to form strong ion pairs with divalent cations (such as aqueous calcium, magnesium, and iron sulfates) allows $\mathrm{SO}_{4}^{-2}$ concentrations in minewater to substantially exceed saturated $\mathrm{SO}_{4}{ }^{-2}$ concentrations in a single cation system. The contributions of these ion pairs to $\mathrm{SO}_{4}^{-2}$ concentrations must be computed with speciation models before saturation indices for gypsum are computed. The saturation indices for gypsum in 15 of 17 samples were between -0.05 and +0.07 (table 9), indicating gypsum was near saturation in most ground water. The two samples significantly below saturation

${ }^{1}$ Unit follows usage of Missouri Division of Geology and Land Survey. 


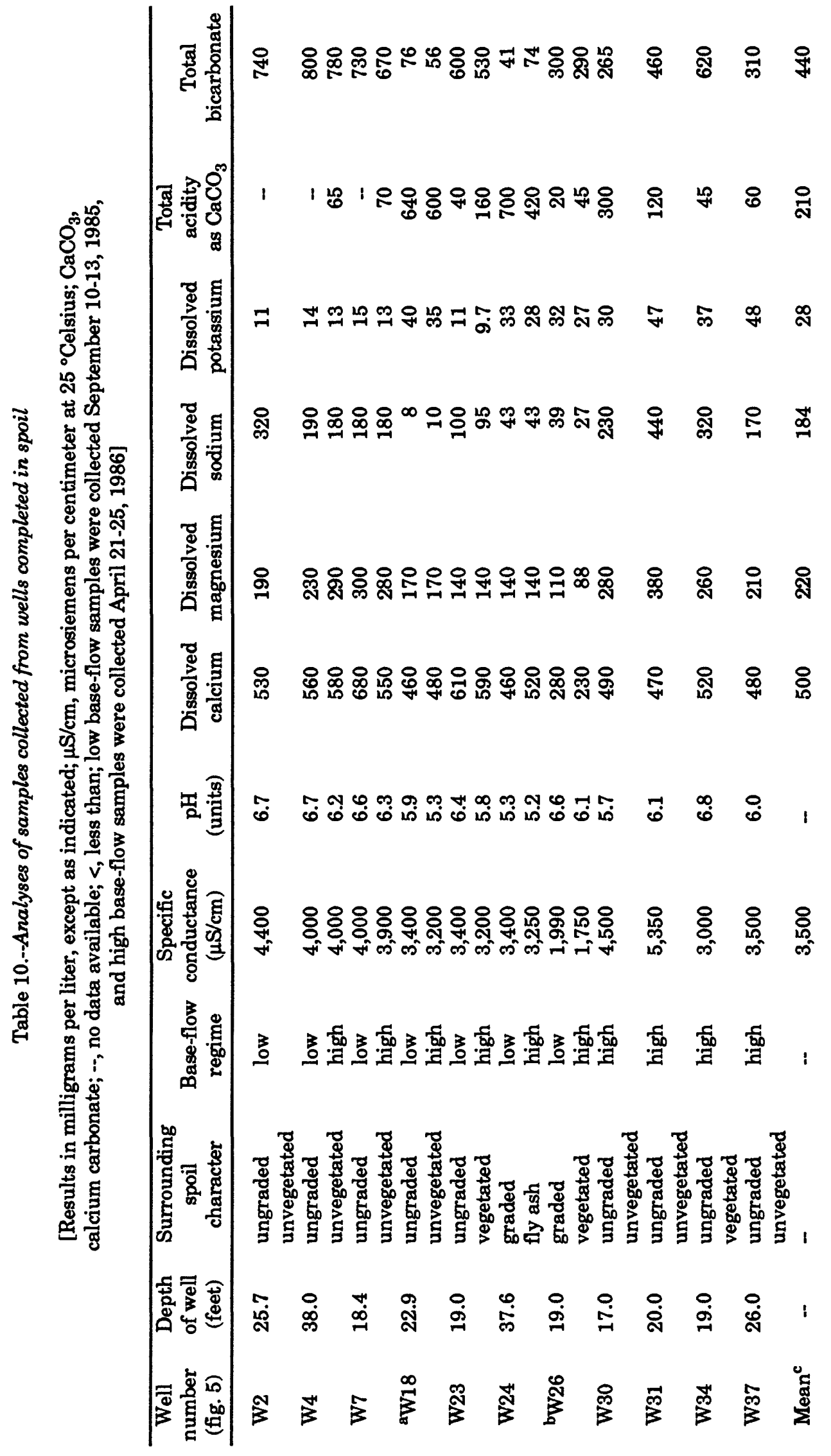




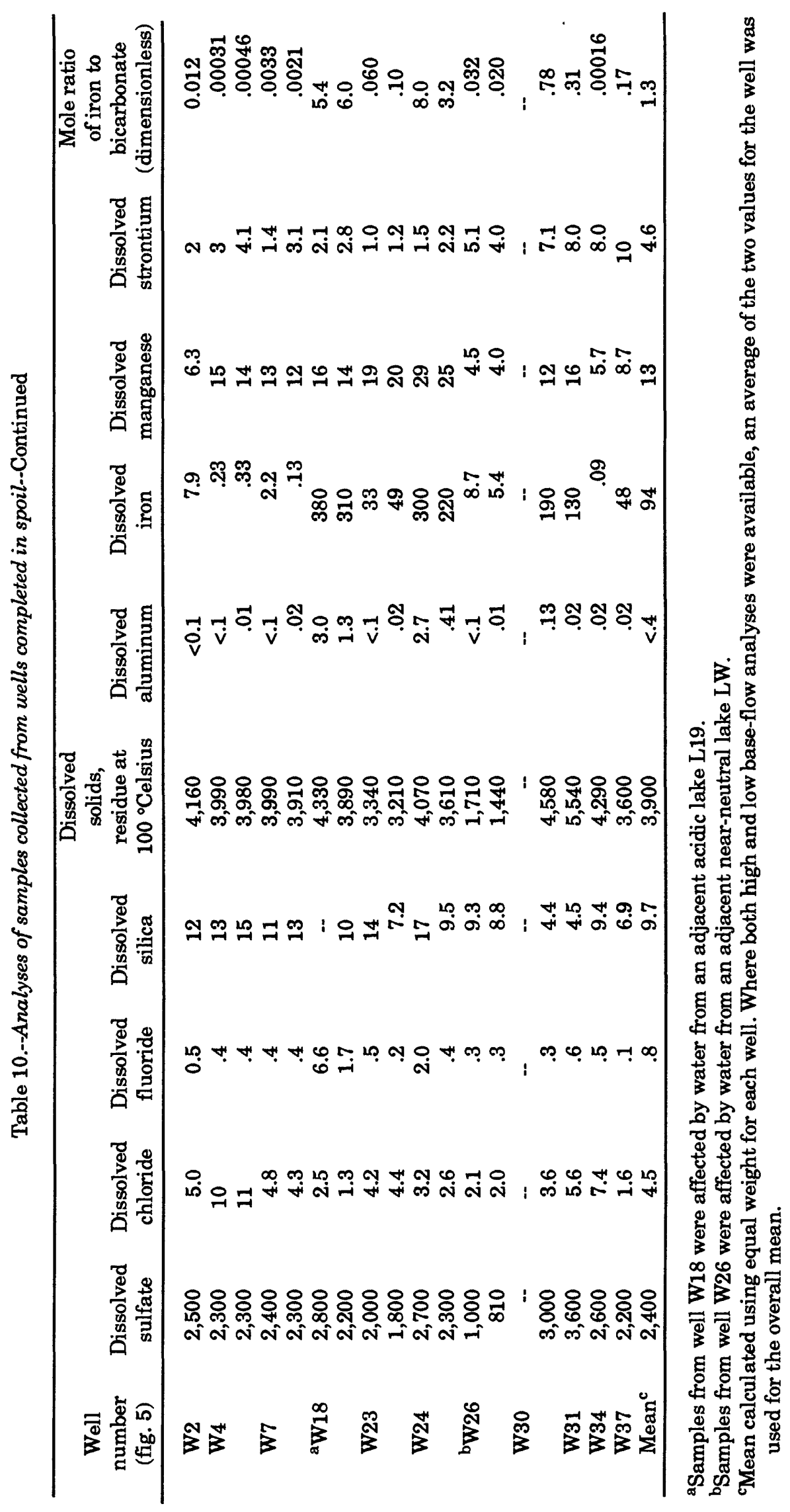




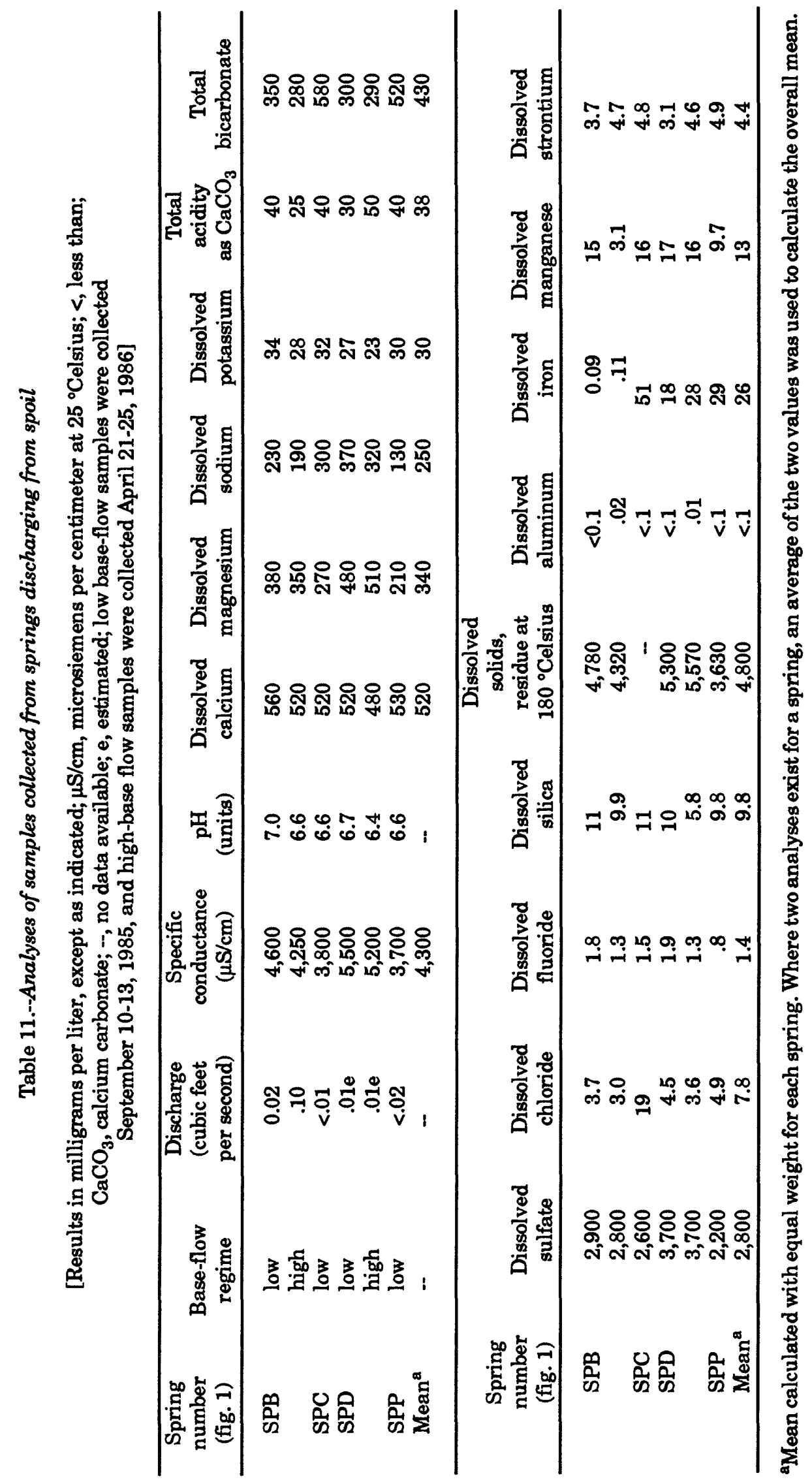


were from a well (W26) within $30 \mathrm{ft}$ of a recharge lake. As previously mentioned, when the $\mathrm{pH}$ is greater than 6.4, ground water also is saturated with calcite. Combining the solubility equilibria for dissolution of calcite and gypsum leads to the expression

$$
\frac{\left[\mathrm{SO}_{4}^{-2}\right]\left[\mathrm{H}^{+1}\right]}{\left[\mathrm{HCO}_{3}^{-1}\right]}=10^{-6.5}
$$

where the brackets denote activities (Hem, 1985). This expression can be useful for predicting changes in groundwater chemistry if changes or amendments are made that change one of these three constituents, or for predicting whether more gypsum or calcite will dissolve before equilibrium is reached.

Aluminum $\left(\mathrm{Al}^{+3}\right)$ concentrations often were below or near the detection limits (tables 10 and 11) probably because of minimal solubility of $\mathrm{Al}^{+3}$ at $\mathrm{pH}$ values near 6.0 with respect to gibbsite $\mathrm{Al}(\mathrm{OH})_{3}(\mathrm{Hem}, 1985)$, although several sulfates and silicates of $\mathrm{Al}^{+3}$ also were near or above saturation (table 9). Larger concentrations of $\mathrm{Al}^{+3}$ occurred in water from wells completed in fly ash and near acidic recharge lakes where $\mathrm{pH}$ values were lower (5.25.9) and $\mathrm{F}^{-1}$ (fluoride) concentrations were higher (0.4-6.6 $\mathrm{mg} / \mathrm{L}$ ) than in water from other wells. AlF-1 complexes are strong and can cause higher concentrations of dissolved $\mathrm{Al}^{+3}$ (Hem, 1985).

Fe concentrations ranged from 0.09 to $380 \mathrm{mg} / \mathrm{L}$. Larger concentrations were detected in samples with $\mathrm{pH}$ values between 5.3 and 6.1 and lower concentrations in samples with $\mathrm{pH}$ values between 6.2 and 6.8 (tables 10 and 11). It is not likely that the larger concentrations of $\mathrm{Fe}$ come from pyrite oxidation below the water table. Large quantities of $\mathrm{Fe}^{+3}$ are required for the bacterially catalyzed reaction path (reactions 1 and 2) and $\mathrm{O}_{2}$ is required for the much slower abiotic path (reactions 1 and 3). Only minute quantities of $\mathrm{Fe}^{+3}$ can be available at the typical $\mathrm{pH}(5.2-6.8)$ of ground water in the spoil (reaction 5) and dissolved oxygen usually was less than the detection limit of $0.1 \mathrm{mg} / \mathrm{L}$. Pyrite oxidation does occur near the acidic spoil surface where both $\mathrm{Fe}^{+3}$ and $\mathrm{O}_{2}$ are available. Even at near-surface potentials as high as 0.7 volt, a substantial part of the dissolved $\mathrm{Fe}$ is $\mathrm{Fe}^{+2}$ at low $\mathrm{pH}$ values. Blevins and Chafin (1988) showed that most $\mathrm{SO}_{4}^{-2}$ in ground water is from pyrite oxidation, and because most of this oxidation occurs near the surface, it is likely that some $\mathrm{Fe}^{+2}$ also is leached to the water table where lower potentials would stabilize $\mathrm{Fe}^{+2}$ even at the larger $\mathrm{pH}$ values.

Another large source of Fe in ground water is the abundant siderite in nodules and disseminated throughout limestones, sandstones, and shales in the area. Fe also may have been removed by precipitation of siderite in some cases. Eight of 17 ground-water samples were determined to be near or above saturation with siderite (table 9). No other plausible $\mathrm{Fe}^{+2}$ minerals were determined to be near saturation. Mn was similar to $\mathrm{Fe}$ in that rhodochrosite $\left(\mathrm{MnCO}_{3}\right)$ was near or above saturation in 7 of 17 samples.

Although strongly affected by small changes in Eh, ferrihydrite and potassium jarosite were usually near or above saturation at an Eh of 0.25 . Also, most cuttings from wells drilled in spoil below the water table were colored with iron hydroxides, indicating ferrihydrite or jarosite, or both, were usually saturated in the ground water and limited concentrations of $\mathrm{Fe}^{+3}$.

\section{Lake and Base-Flow Chemistry}

Shallow perched lakes (averaging less than $8 \mathrm{ft}$ deep) on spoil usually had a pH values less than 4.0 (tables 6 and 12 and fig. 18). These lakes received little or no ground water to neutralize acidic runoff or produce sustained outflow. Although acidic, these lakes had low concentrations of $\mathrm{Ca}^{+2}, \mathrm{Mg}^{+2}, \mathrm{Na}^{+1}, \mathrm{SO}_{4}^{-2}$, and $\mathrm{Fe}$ because their only source of water, acidic runoff, also had low concentrations of these constituents. The perched lakes usually were clear with no visible Fe precipitates.

However, several shallow lakes, including lakes LA, LP, LT, and LGG, received substantial quantities of ground water with large Fe concentrations and also were acidic (table 13). These ground-water-supplied lakes were the primary sources of acidic base flow in the study area. The acidification occurring in these shallow lakes primarily was from oxidation of large concentrations of $\mathrm{Fe}^{+2}$ (reaction 5 ) in the ground water that supplies them. Also, acidic runoff and some iron disulfides from bare spoil were received by these lakes during rain storms. However, little change in $\mathrm{pH}$ value of lake LP occurred regardless of wet or dry weather, which indicates that the oxidation of $\mathrm{Fe}^{+2}$ from the steady supply of ground water was the primary source of $\mathrm{H}^{+1}$. 


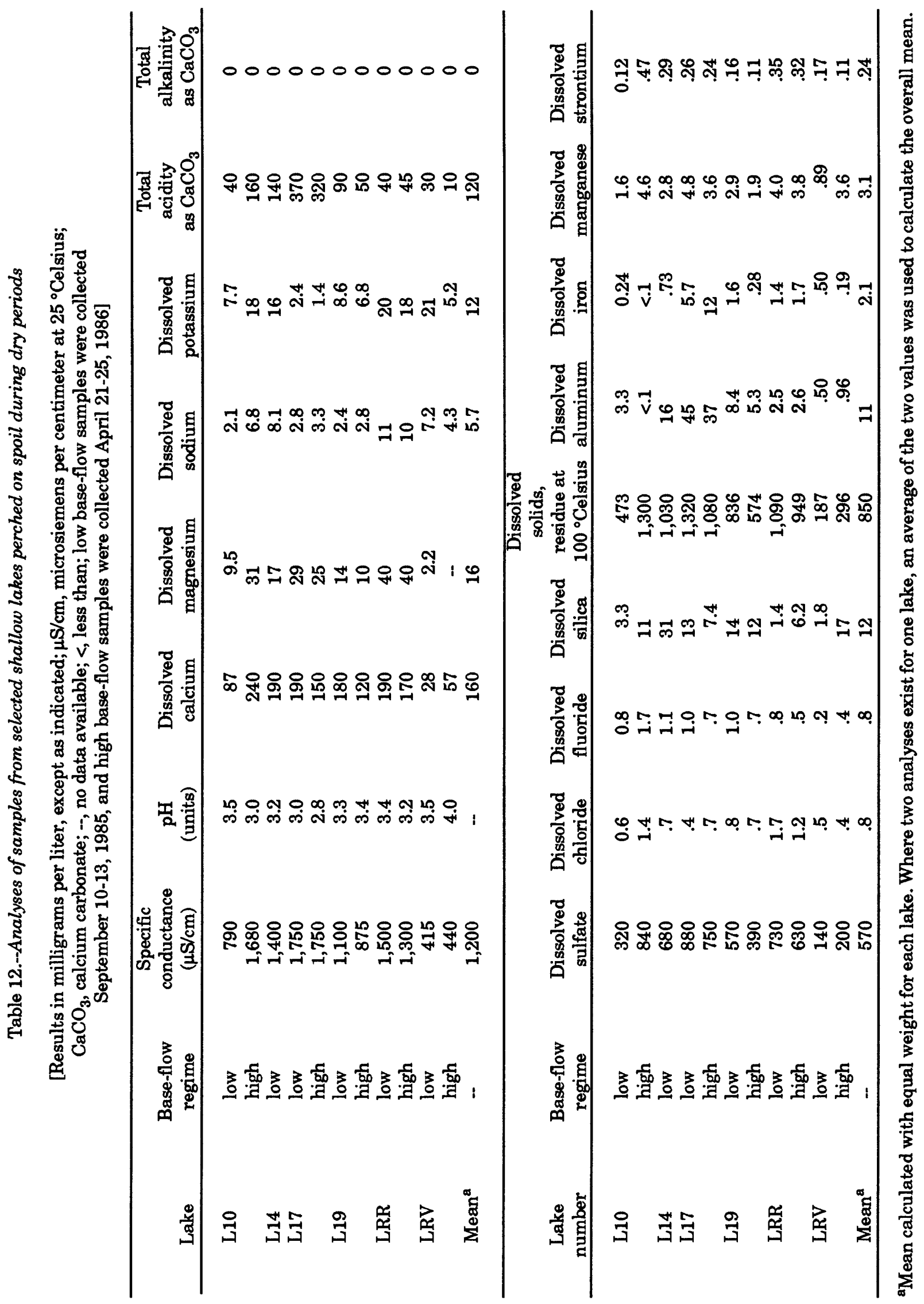




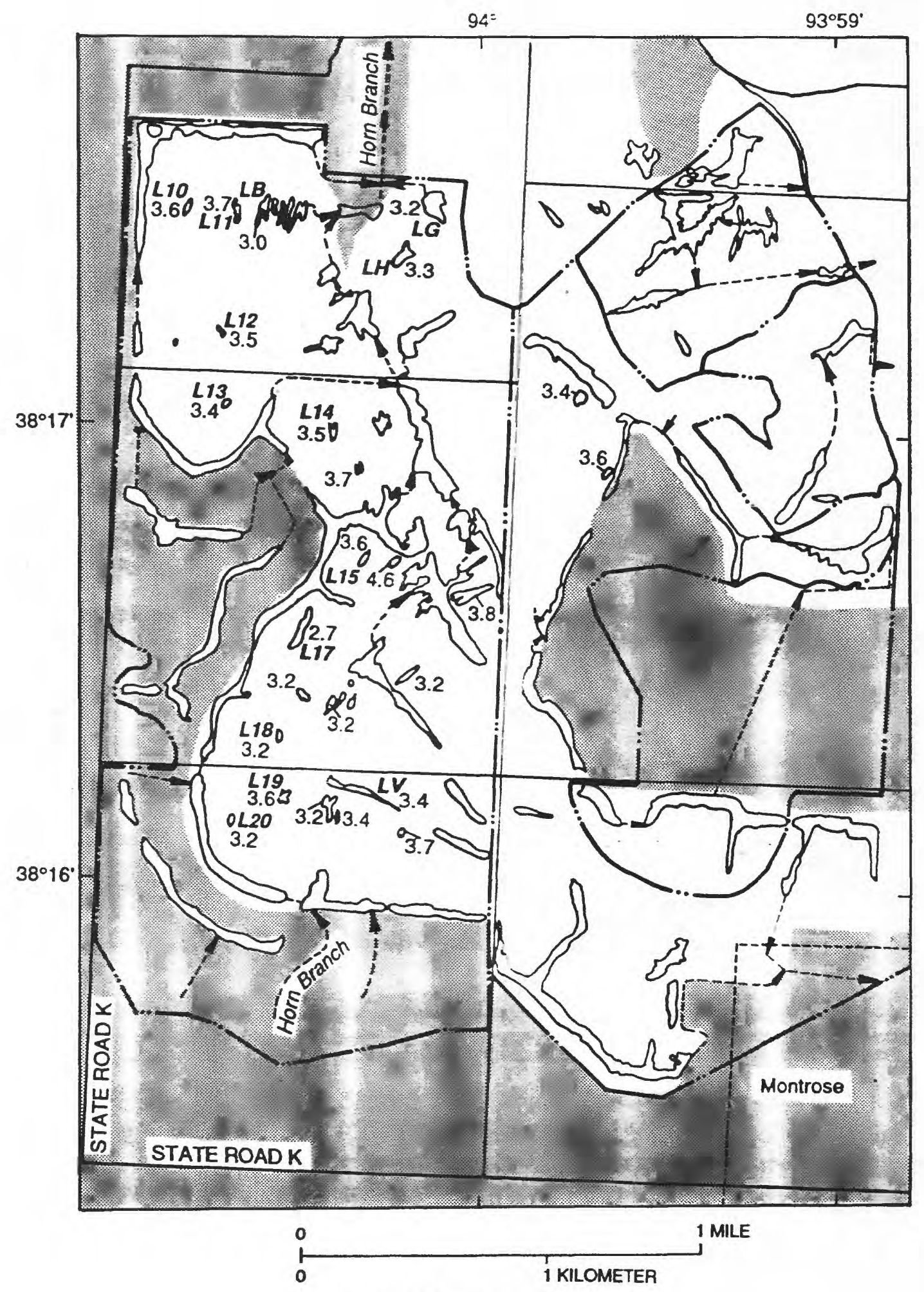

EXPLANATION
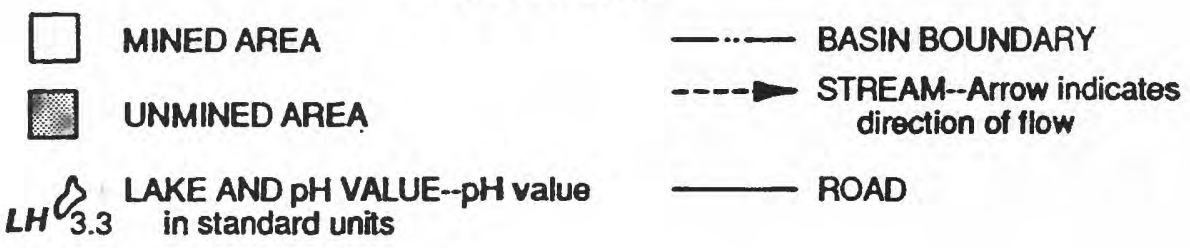

Figure 18.--pH value of selected shallow lakes in mined areas. 


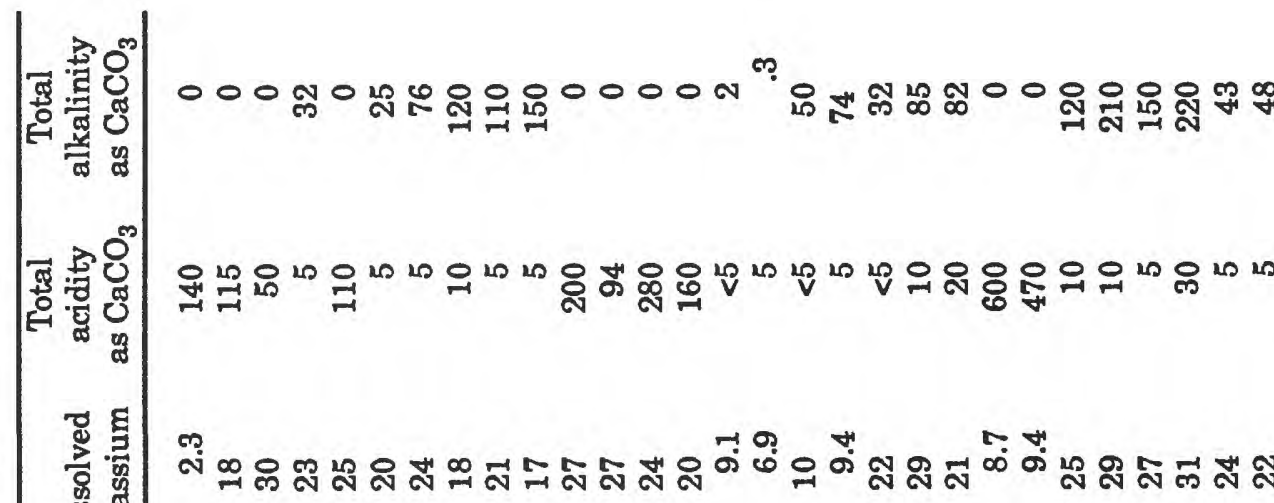

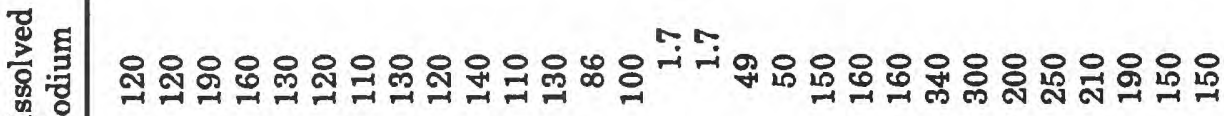

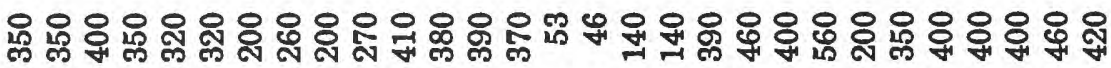

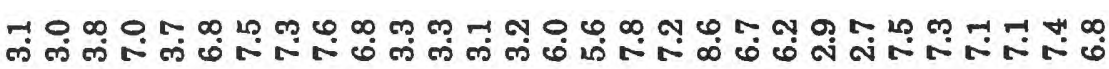

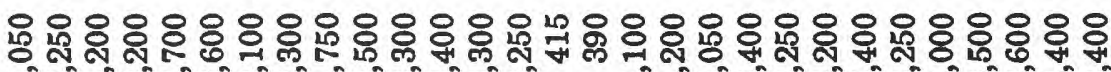

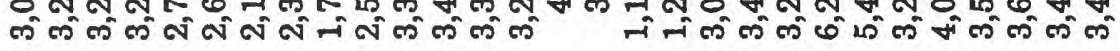

$\approx$

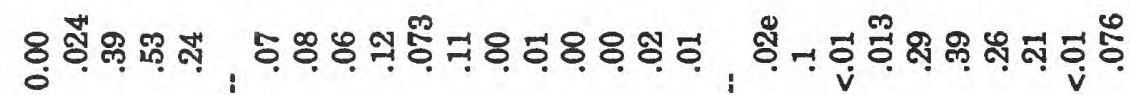

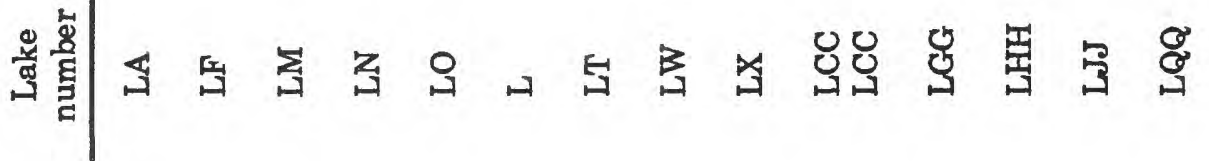




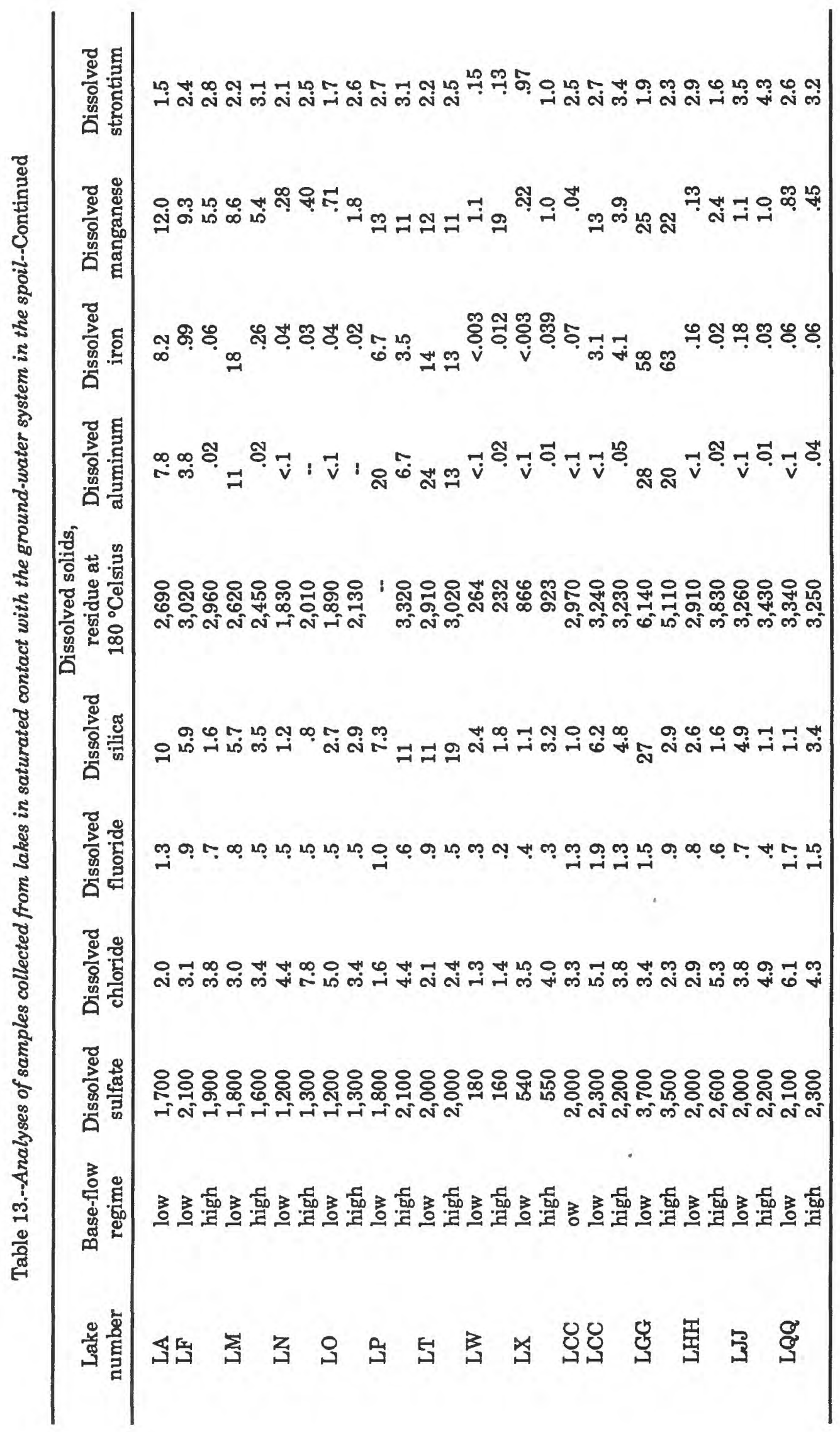


The Eh of outflow from the shallow, acidic lake LP on September 24, 1987, measured 0.71 volt. This Eh matched the value calculated using the $\mathrm{Fe}^{+3}$ to $\mathrm{Fe}^{+2}$ ratio in the Nernst equation, which supports the contention of Nordstrom and others (1979) that Eh measurements in acidic streams with large Fe concentrations are reliable if done correctly. At this $\mathrm{Eh}$, most of the dissolved $\mathrm{Fe}$ was $\mathrm{Fe}^{+3}$ and although concentrations of ferrihydrite were less than saturation because of low $\mathrm{pH}$ values, jarosite was oversaturated. Acidic lakes receiving ground water were a dark, but transparent, red color from relatively high concentrations of Fe compared with the clear perched lakes. The transparency may have been caused by the undersaturation of ferrihydrite. Concentrations of $\mathrm{Fe}$ in the acidic lakes receiving ground water, while higher than perched lakes, were substantially lower than groundwater concentrations, reflecting the precipitation of Fe required to acidify the lakes. These lakes retained other chemical characteristics of ground water, such as high concentrations of $\mathrm{Ca}^{+2}, \mathrm{Mg}^{+2}, \mathrm{Na}^{+1}$, and $\mathrm{SO}_{4}^{-2}$. Large concentrations of $\mathrm{SO}_{4}^{-2}$ in ground-water-supplied lakes had a buffering effect when the $\mathrm{pH}$ was less than about 3.5. According to WATEQ4F calculations, at a $\mathrm{pH}$ of 3.0, the large quantities of $\mathrm{SO}_{4}^{-2}$ in lake LA caused the quantity of $\mathrm{H}^{+1}$ in the form of $\mathrm{HSO}_{4}^{-1}$ to be 40 percent of the quantity of free $\mathrm{H}^{+1}$. Dissolved $\mathrm{Al}^{+3}$ concentrations primarily were a function of $\mathrm{pH}$ value with concentrations as large as $45 \mathrm{mg} / \mathrm{L}$ in acidic lakes (lake L17, table 12) but less than $0.1 \mathrm{mg} / \mathrm{L}$ in neutral lakes (tables 12 and 13 ).

Most deep lakes (average depth greater than $9 \mathrm{ft}$ ) had near-neutral $\mathrm{pH}$ values and dissolved concentrations of Fe less than $0.25 \mathrm{mg} / \mathrm{L}$ (depth and $\mathrm{pH}$ value in table 3 and fig. 19; Fe concentration in tables 7 and 13). Even at these low concentrations, WATEQ4F calculated saturation indices for ferrihydrite and potassium jarosite greater than 1.0 with arbitrary Eh values as low as 0.30 . Evidently, most Fe entering the deep lakes with ground water was oxidized by atmospheric oxygen and precipitated at near neutral $\mathrm{pH}$. The transparency of these lakes was usually less than the shallow lakes and some of the neutral, ground-water-supplied lakes were occasionally an opaque, bright orange from suspended iron hydroxides. The chemical character of deep lakes that received ground water, such as lakes LN, LO, LX, and LHH was similar to ground water except the lake water was somewhat diluted from rainfall and surface runoff. These characteristics included near-neutral $\mathrm{pH}$ values and large concentrations of $\mathrm{Ca}^{+2}, \mathrm{Mg}^{+2}, \mathrm{Na}^{+1}$, and $\mathrm{SO}_{4}^{-2}$. The $\mathrm{pH}$ value of these lakes is somewhat surprising because shallow lakes receiving ground water are acidified by Fe oxidation. Two factors, in varying degrees, may account for the near-neutral $\mathrm{pH}$ values. Most of the deeper lakes, such as lakes LN, LO, LQ, LU, LX, LY, LZ, LHH, LKK, LLL, LMM, LNN, LOO, and LPP, receive substantial quantities of near-neutral runoff from unmined or topsoiled drainage areas. Also, large variability existed in the Fe concentrations of ground water (table 10). If the mole ratio of $\mathrm{Fe}^{+2}$ to $\mathrm{HCO}_{3}^{-1}$ in near-neutral ground water was less than 0.5 , then, theoretically, acidification below a $\mathrm{pH}$ of about 5 could not occur according to:

$$
\mathrm{Fe}^{+2}+5 / 2 \mathrm{H}_{2} \mathrm{O}+1 / 4 \mathrm{O}_{2}+2 \mathrm{HCO}_{3}^{-1} \rightarrow \mathrm{Fe}(\mathrm{OH})_{3}+2 \mathrm{H}_{2} \mathrm{CO}_{3} \text {. }
$$

Therefore, some of the deeper lakes may not acidify because the $\mathrm{Fe}$ to $\mathrm{HCO}_{3}^{-1}$ ratio in most ground-water samples was less than 0.5 (table 10). Exceptions were wells W18 (affected by an adjacent acidic recharge lake), W24 (affected by fly ash), W30, and W31. Wells W30 and W31 are upgradient from two shallow acidic ground-watersupplied lakes LT and LV. It is doubtful that the depth of the lake is a direct factor in keeping lake water near neutral, except for the tendency of deep lakes to receive a larger and more integrated quantity of ground water than shallow lakes. Stratification and low concentrations of dissolved oxygen at depth could decrease Fe oxidation and consequent acidification. However, only small concentrations of $\mathrm{Fe}$ were detected in outflows from deep, neutral lakes. Larger concentrations would be expected if $\mathrm{Fe}$ oxidation was limited and $\mathrm{Fe}$ remained as $\mathrm{Fe}^{+2}$.

Horn Branch forked into two primary tributaries that had substantial effects on the water chemistry downstream during base flow. Outflows from lakes LN and LX (fig. 19) had near neutral pH values and formed the western tributary. Outflows from lakes LP, LS, and LT at site Q2 always were acidic and formed the eastern tributary. The two tributaries flowed into lake LM where mixing occurred. Continuous pH data (figs. 15-17) collected at site G1 and data collected during synoptic sampling (table 13) indicate that during high base flow, neutral water from lake LN dominated the water chemistry downstream and during low base flow acidic water from lake LP dominated water chemistry downstream. Although lake LN released more base flow than lake LP, base flow from lake LN ceased sooner than from lake LP during dry late-summer periods, possibly because of larger evaporation losses from lakes LN, LU, LX, LY, and LZ. Also, onsite experiments confirmed that the $\mathrm{pH}$ value of an equal mixture of lake LN and lake LP outflow was closer to the $\mathrm{pH}$ value of lake LP than lake $\mathrm{LN}$ because $\mathrm{pH}$ is a logarithmic measure of the $\mathrm{H}^{+1}$ concentration. Consequently, the $\mathrm{pH}$ at site $\mathrm{Q} 1$ usually was between 3.0 and 4.0 for a few months in the summer and between 5.5 and 7.0 for the rest of the year. 


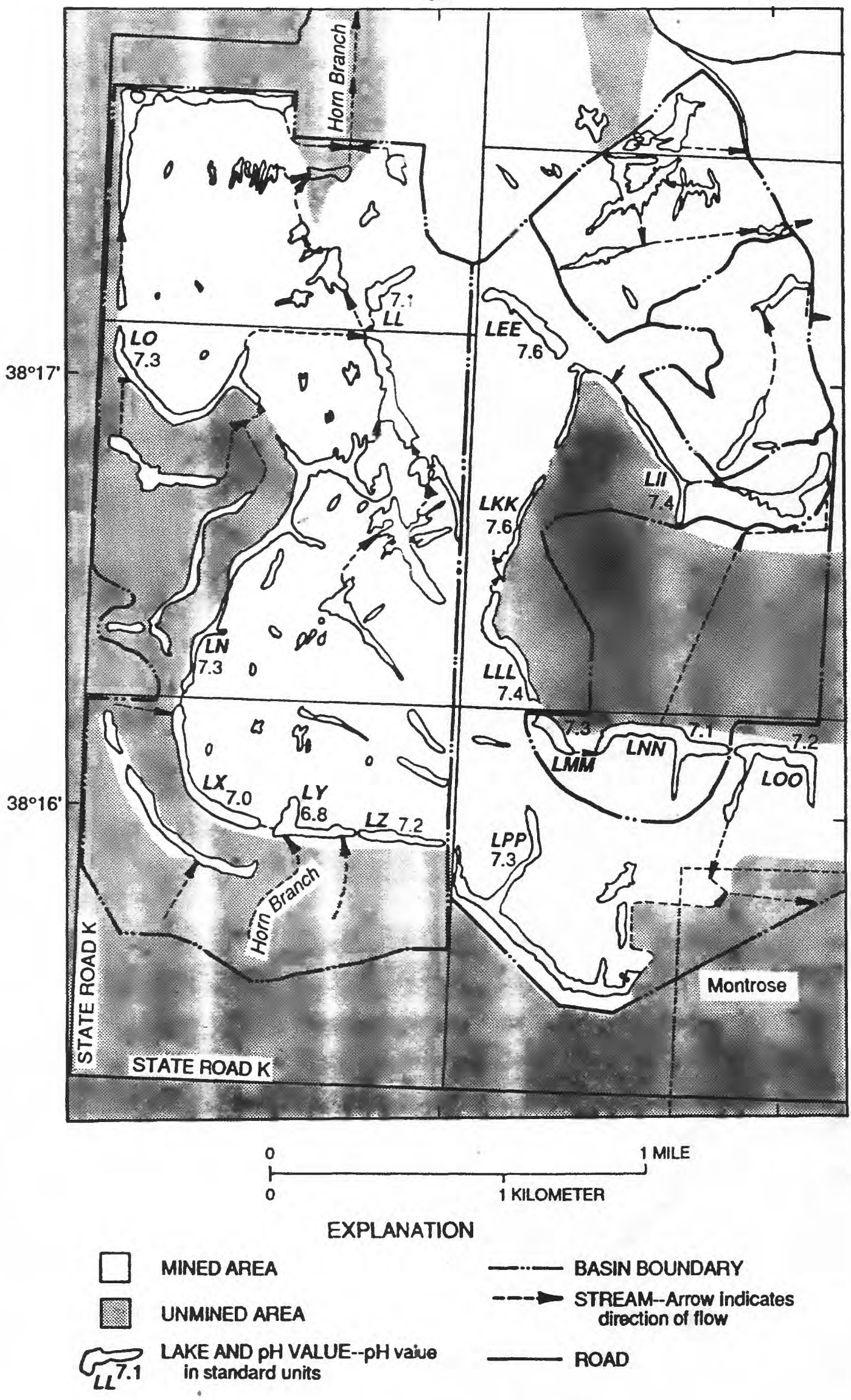

Figure 19.--pH value of deep lakes, September 1984. 
Continuous pH data collected at site Q3 from June 29 to December 15, 1984, and from March 20 to June 25,1985 , and frequent instantaneous $\mathrm{pH}$ measurements collected during other periods ranged from 6.2 to 8.4. Drainage from lakes LII, LJJ, LKK, and LLL were included in the flow at G3. All instantaneous measurements of $\mathrm{pH}$ of the outflows from these last-cut, ground-water-supplied lakes always were greater than 6.0 (figs. 7-9).

Lake LGG had the lowest measured pH in the study area of 2.7 (table 13). Outflow from LGG contributed to the low $\mathrm{pH}$ of 3.5 at lake LFF on April 18, 1985 (fig. 7), which then drained out of the study area. Small quantities of the outflow from lake $L Q Q$ also left the study area. The $\mathrm{pH}$ value of this lake fluctuated depending on the relative contributions from acidic lake LRR and the near-neutral lakes LCC and LDD and the seeps between lakes LCC and LQQ.

\section{Geochemical Processes and Conditions Occurring on Unreclaimed Spoil}

Geochemical conditions and processes occurring in and on unreclaimed mine spoil in the study area are summarized in figures 20 and 21. The water-quality patterns of storm runoff and perched lakes are similar. Both waters are acidified by dissolution of ferric-sulfate and $\mathrm{HSO}_{4}^{-1}$ salts (acidic water is identified in figure 20 by the absence of $\mathrm{HCO}_{3}^{-1}$ ). Dissolution of calcite and secondary gypsum are the most likely sources of $\mathrm{Ca}^{+2}$ detected in runoff. Near the surface where oxygen is available, iron-disulfide oxidation acidifies spoil. After this water reaches the water table, $\mathrm{O}_{2}$ concentrations at depth are depleted, and calcite and siderite are dissolved, neutralizing acidic recharge and increasing concentrations of $\mathrm{Ca}^{+2}, \mathrm{Mg}^{+2}, \mathrm{SO}_{4}^{-2}$, and $\mathrm{Fe}^{+2}$. Consequently, the water-quality pattern for ground water has a characteristic shape, which also can be seen in ground-watersupplied lakes and in base flows draining the spoil. The resulting surface outflows from unreclaimed spoil are mixtures of acidic and near-neutral base flows, acidic runoff from unvegetated spoil, and near-neutral runoff unmined areas. Effects of acidic runoff are minimized by lakes with small or no outflows that trap acidic runoff and increase base flows. However, base flow from shallow, acidic, ground-water-supplied lakes occasionally acidifies receiving streams for a considerable distance downstream, primarily during late summer months. The $\mathrm{pH}$ value of base flow depends on the relative contribution of the deep, near-neutral lakes and the shallow, acidic lakes. 

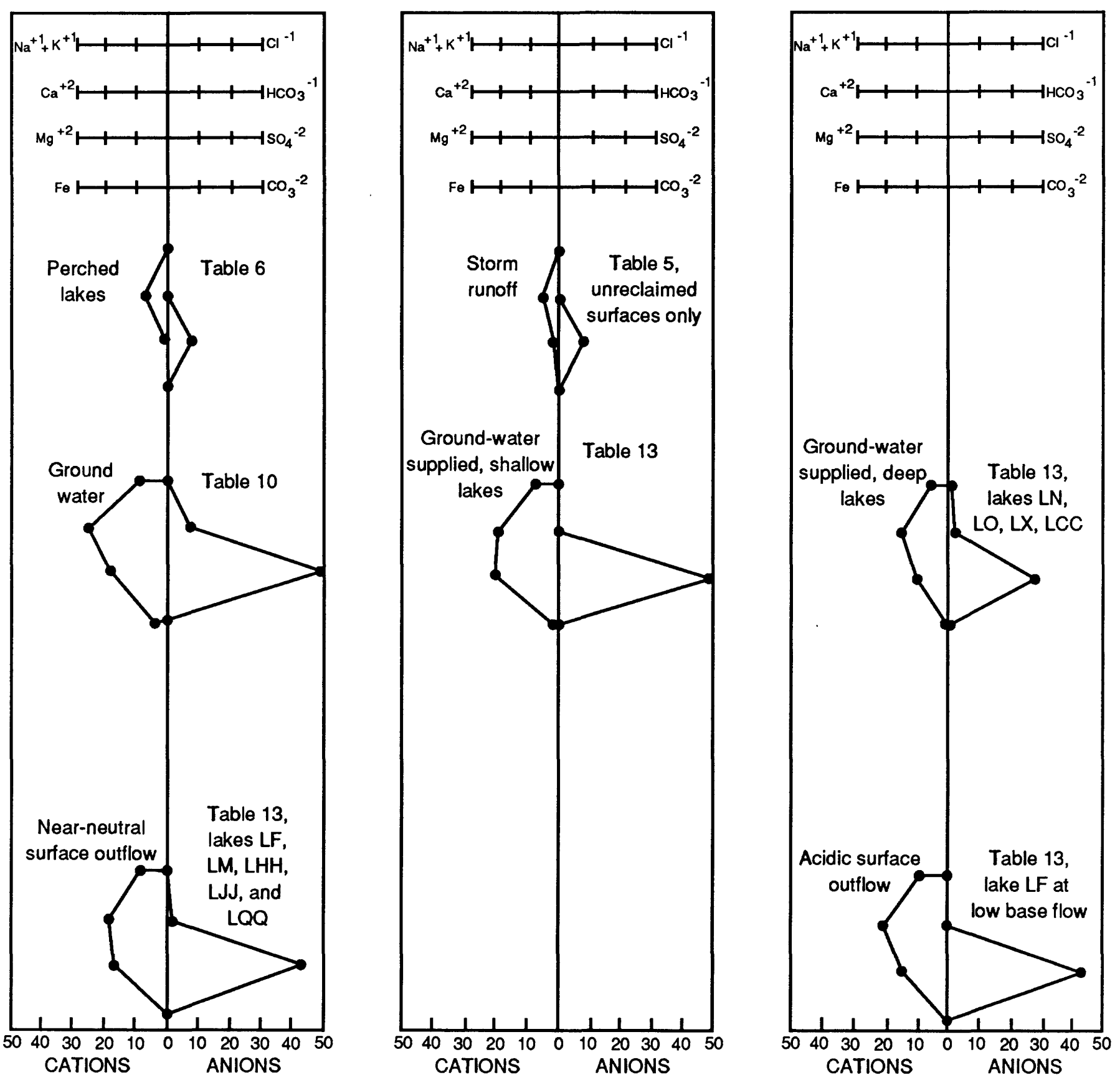

MILLIEQUIVALENTS PER LITER

EXPLANATION

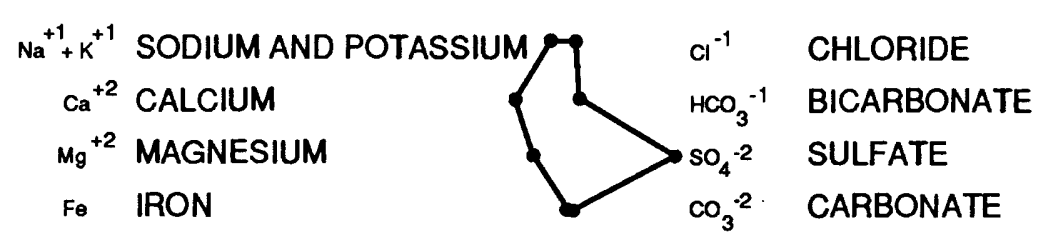

Figure 20.--Pattern plots of mean concentrations of selected constituents in storm runoff, perched lakes, ground water, shallow ground-water-supplied lakes, deep ground-water-supplied lakes, and two types of surface outflow leaving the study area. 


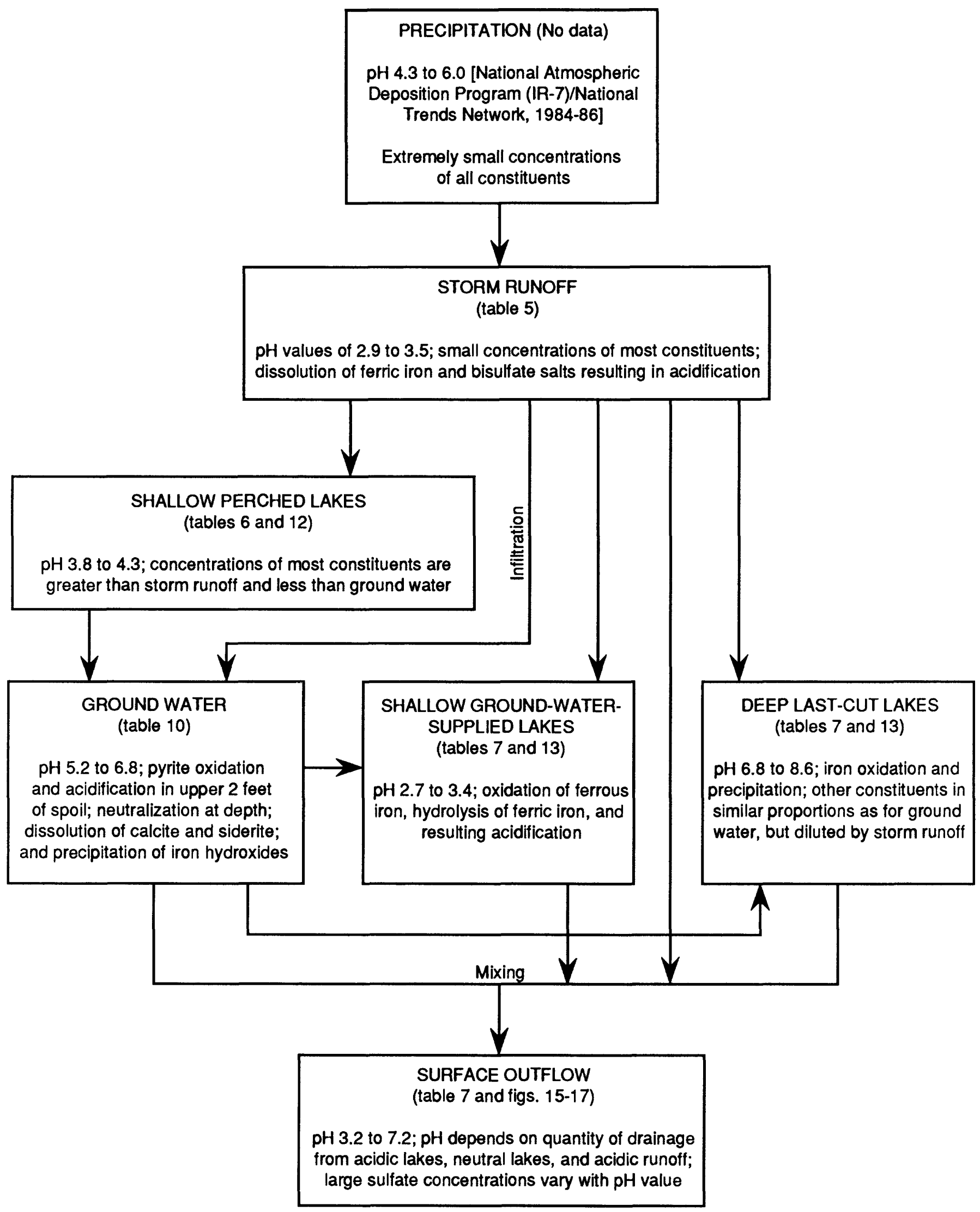

Figure 21.--Flow chart of evolution of water chemistry in mined area. 


\section{SUMMARY AND CONCLUSIONS}

The 2,400 acres of abandoned surface-mined land northwest of Montrose, Missouri, contained more than 100 lakes and 1,200 acres of barren, acidic spoil. More than one-half of the lakes had pH values less than 4.0. Most of the acidic spoil was drained by Horn Branch.

Surface drainage was mostly from lake to lake until it left the mined area. A part of the mined area has internal drainage ( 20 percent of the Horn Branch basin) due to ridges of spoil material that block drainage paths. Consequently, unit peak discharges were 28 and 53 percent less than 2 larger unmined areas nearby. As the lakes that trapped runoff filled with sediment from the rapidly eroding spoil, the capability to reduce runoff in the mined area decreased. Forty-seven percent of the runoff from the Horn Branch basin was caused by precipitation falling directly on lakes having outflow.

Ground water in the spoil had a water-table surface and was bounded on the bottom and sides by Pennsylvanian rocks of low permeability. The sides of the spoil aquifer usually were marked by linear, last-cut lakes that fully penetrated the aquifer and received ground-water discharge. The saturated spoil averaged $30 \mathrm{ft}$ thick. The direction of ground-water flow in the spoil was controlled by the location and altitude of lakes recharging the spoil relative to the altitude of last-cut lakes receiving ground water from the spoil. Most of the recharge to the spoil aquifer came from leakage from shallow lakes formed between ridges of spoil. Consequently, as these ridges erode and the lakes disappear, ground-water levels and base-flow volumes will decrease.

Samples of overland runoff from bare mine spoil and fly ash had $\mathrm{pH}$ values between 2.9 and 3.5. Two runoff samples from revegetated spoil had pH values 2 to 3 units higher than runoff from bare spoil, which indicates that successful revegetation of spoil substantially increases the $\mathrm{pH}$ value of runoff. Although overland runoff was more dilute than any other water in the mine, substantial $\mathrm{Ca}^{+2}$ and $\mathrm{SO}_{4}{ }^{-2}$ concentrations in five samples from bare mine spoil indicate secondary gypsum quickly dissolved in runoff. The $\mathrm{pH}$ value of streamflow leaving the mine was only minimally affected by acidic overland runoff because the large quantity of near-neutral lake water in the stream system moderated fluctuations in $\mathrm{pH}$. Also, areas of internal drainage prevented much acidic runoff from reaching streams. One large 3-in. rainfall on May 13,1985, decreased the $\mathrm{pH}$ value in Horn Branch to 4.8, but runoff sometimes increased the $\mathrm{pH}$ value in Horn Branch if prestorm values were less than 5.0. The higher $\mathrm{pH}$ values were caused by flushing of near-neutral water from several large lakes upstream, such as lakes LN, LO, LX, LY, and LZ.

The $\mathrm{pH}$ of ground water was usually between 5.7 and 6.8 , except in fly ash and near a few acidic recharge lakes where the $\mathrm{pH}$ was less than 4.0 during wet weather. Ground water usually was not acidic because oxygen was not present in sufficient quantities to oxidize pyrite in the spoil. A few feet below the surface and at depth, carbonate rocks were present in sufficient quantity to neutralize the acidic recharge from lakes or the spoil surface. As this acidic recharge dissolved calcium carbonate at depth, the water became saturated with gypsum. Calcite also reached saturation if the $\mathrm{pH}$ was greater than 6.4. Concentrations of dissolved $\mathrm{SO}_{4}^{-2}$ in ground water were large, partly because of the tendency of $\mathrm{SO}_{4}^{-2}$ to form ion pairs such as aqueous calcium, magnesium, and iron sulfate. Reducing conditions in the spoil allowed concentrations of $\mathrm{Fe}^{+2}$ to average $93 \mathrm{mg} / \mathrm{L}$, which oxidized and formed precipitates of $\mathrm{Fe}^{+3}$ minerals in the few shallow lakes that received ground-water discharge.

Samples of perched lakes had $\mathrm{pH}$ values between 2.8 and 4.3. The $\mathrm{pH}$ of lakes averaging more than $9 \mathrm{ft}$ deep was greater than 6.0, probably because the deeper lakes received larger quantities of near-neutral runoff from unmined and topsoiled areas and they received ground water with lower $\mathrm{Fe}$ to $\mathrm{HCO}_{3}^{-1}$ ratios. A few shallow lakes intercepted the water table and received ground-water discharge. Water in these lakes was acidified to a $\mathrm{pH}$ between 2.7 and 3.4 and produced sustained outflows that had pronounced effects downstream. The $\mathrm{pH}$ of base flow in Horn Branch where it left the mine (site Q1) was lowered to less than 4.0 during the dry summer months by sustained outflow from shallow, ground-water-supplied lakes. The rest of the year, outflows from the nearneutral lake LN were large enough to dominate the water chemistry in the downstream reaches of Horn Branch. 


\section{REFERENCES CITED}

Ball, J.W., and Nordstrom, D.K., 1987, A personal computer Fortran translation of the geochemical model WATEQ2 with revised data base: U.S. Geological Survey Open-File Report 87-50, 108 p.

Barnes, Ivan, and Clark, F.E., 1964, Geochemistry of ground water in mine drainage problems: U.S. Geological Survey Professional Paper 473-A, 6 p.

Blevins, D.W., and Chafin, D.T., 1988, Determination of chemical processes in coal-mined spoil using sulfur and oxygen isotopes, in Proceedings from National Symposium on Mining Hydrology, Sedimentology and Reclamation, University of Kentucky, Lexington, Kentucky, December 5-9, 1988.

Clement, R.W., 1987, Floods in Kansas and techniques for estimating their magnitude and frequency on unregulated streams: U.S. Geological Survey Water Resources Investigations Report 87-4008, 50 p.

Hauth, L.D., 1974, Techniques for estimating the magnitude and frequency of Missouri floods: U.S. Geological Survey Open-File Report 91-89, 20 p.

Hem, J.D., 1985, Study and interpretation of the chemical characteristics of natural water (3rd ed.): U.S. Geological Survey Water-Supply Paper 2254, 263 p.

Kleeschulte, M.J., Mesko, T.O., and Vandike, J.E., 1985, Appraisal of the groundwater resources of Barton, Vernon, and Bates Counties, Missouri: Rolla, Missouri Division of Geology and Land Survey Water Resources Report 36, 80 p.

Koenig, J.W., ed., 1961, The stratigraphic succession in Missouri: Rolla, Missouri Division of Geology and Land Survey, v. XL, Second Series, 185 p.

Linsley, R.K., Kohler, M.K., and Paulus, L.H., 1975, Hydrology for engineers (2nd ed.), McGraw-Hill, 482 p.

Miller, S.D., 1979, Chemistry of a pyrite strip-mine spoil: New Haven, Conn., Yale University, unpublished Ph.D. dissertation, $189 \mathrm{p}$.

National Atmospheric Deposition Program (IR-7)/National Trends Network, 1984-86: NADP/NTN Coordination Office, Natural Resources Ecology Laboratory, Colorado State University, Fort Collins, Colorado.

National Oceanic and Atmospheric Administration, 1984-86a, Climatological data: Asheville, N.C., National Environmental Satellite Data and Information Service, v. 88-90.

1984-86b, Hourly precipitation data: Asheville, North Carolina, National Environmental Satellite Data and Information Service, v. 34-36.

Nordstrom, D.K., 1982, Aqueous pyrite oxidation and the consequent formation of secondary iron minerals--Acid sulfate weathering: Soil Science Society of America Special Publication 10, p. 37-56.

Nordstrom, D.K., Jenne, E.A., and Ball, J.W., 1979, Redox equilibria of iron in acid mine waters, in Jenne, E.A., ed., Chemical modeling in aqueous systems--Speciation, sorption, solubility, and kinetics: American Chemical Society Symposium Series 93, p. 51-79.

Plummer, L.N., Jones, B.F., and Truesdell, A.H., 1976, WATEQF--A fortran version of WATEQ, a computer program for calculating chemical equilibria of natural waters: U.S. Geological Survey Water-Resources Investigations Report 76-13,61 p.

Sato, M., 1960, Oxidation of sulfide ore bodies--I. Oxidation mechanisms of sulfide minerals at $25^{\circ}$ Celsius: Economic Geology, v. 55, p. 1,202-1,231. 
Singer, P.C., and Stumm, Werner, 1970, Acidic mine drainage--The rate determining step: Science, v. 167, p. $1,121-1,123$.

Skougstad, M.W., Fishman, M.J., Friedman, L.C., Erdmann, D.E., and Duncan, S.S., eds., 1979, Methods for determination of inorganic substances in water and fluvial sediments: U.S. Geological Survey Techniques of Water-Resources Investigations, Book 5, Chapter A1, 626 p.

U.S. Weather Bureau, 1959, Evaporation maps for the United States: Technical Paper 37, 13 p.

VomDemfange, W.C., 1974, An investigation of the vertical distribution of sulfur forms in the surface mine spoils, Henry County, Missouri: Rolla, University of Missouri, unpublished M.S. thesis, 59 p.

Weiss, J.S. and Razem, A.C., 1984, Simulation of ground-water flow in a mined basin in eastern Ohio: Ground Water, v. 22, no. $5,12 \mathrm{p}$. 